\title{
UC-NRLF
}

B ᄅ 506885 


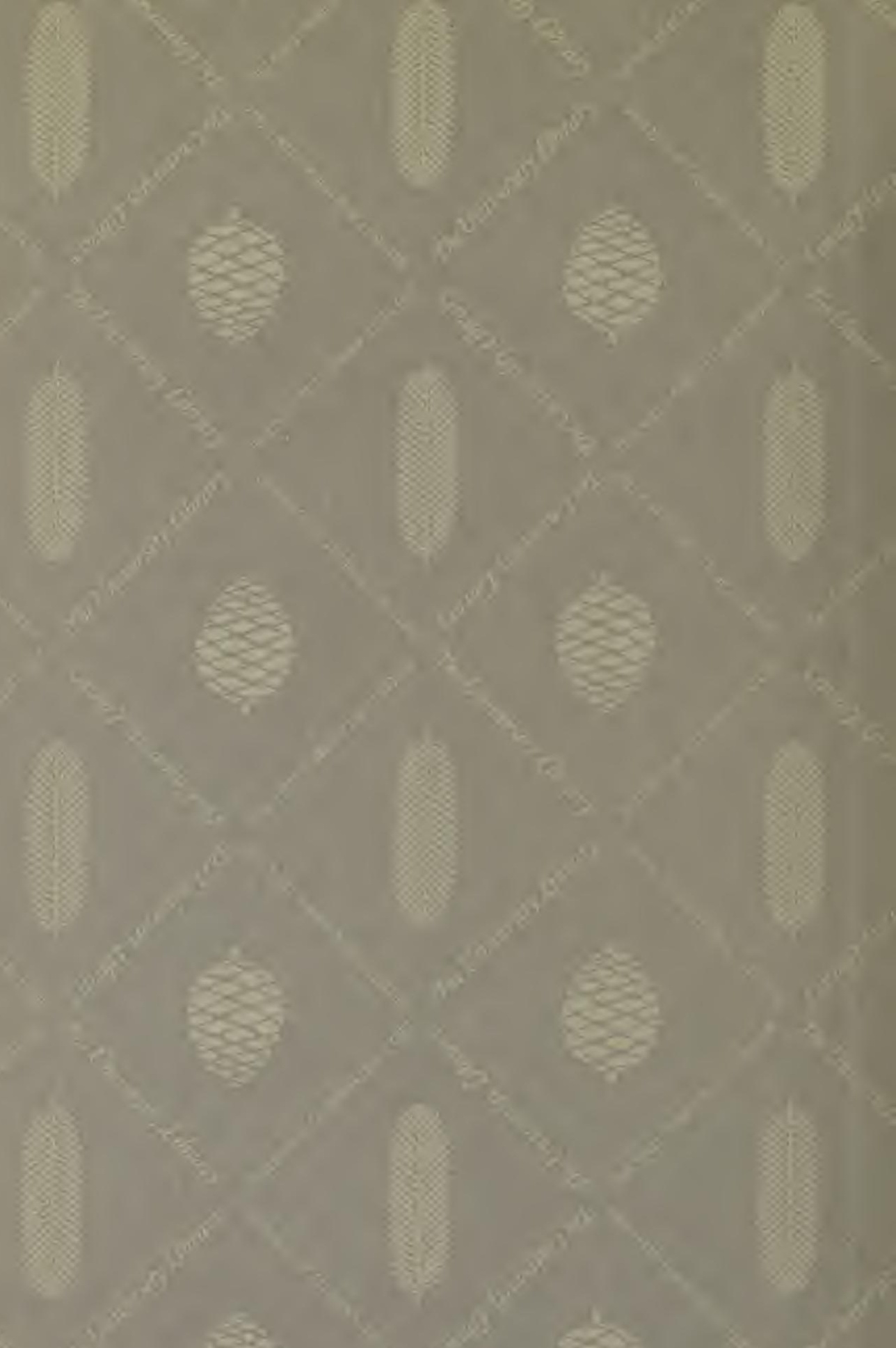




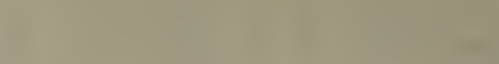

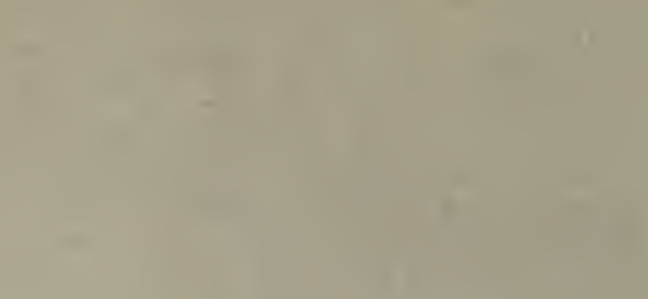

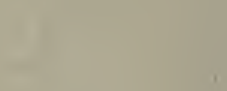

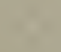




\section{The Structure and Life-History of the \\ Hay-Scented Fern.}

BY

HENRY SHOEMAKER CONARD, PH. D.

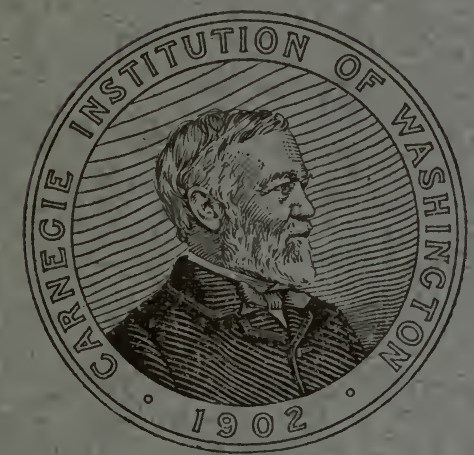

WASHINGTON, D. C.

Published By the Carnegie Institution of Washington. I 908 . 


\section{The Structure and Life-History of the}

\section{Hay-Scented Fern.}

BY

HENRY SHOEMAKER CONARD, PH. D.

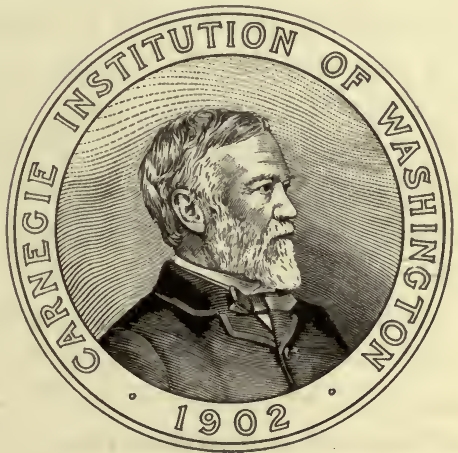

WASHINGTON, D. C.

Published by the Carnegie Institution of Washington. 1908 . 
CARNEGIE INSTITUTION OF WASHINGTON

Publication No. 94

THE CORNMAN. PRINTING Co., CA RI. ISLE, PA. 


\section{PREFACE.}

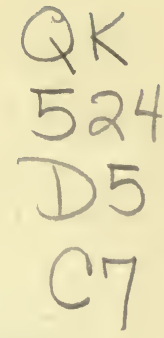

Aside from certain personal interests and opinions, the impulse to the present investigation came from a study of recent papers by Jeffrey, Boodle, and Gwynne-Vaughan. But since we shall never know the true relations of a plant to its surroundings until we have worked out its complete lifehistory, it seemed to me very desirable to have all of our knowledge of this species collected into a unit. Therefore the study was carried beyond the problems suggested by the papers referred to.

The work was begun in odd moments of an instructorship at the University of Pennsylvania, but nearly all of it was actually done in the Botanical Laboratory of the Johns Hopkins University, and this paper is to be regarded as Contribution No. 7 from that Laboratory. I was there as "James Buchanan Johnston Scholar" from February, 1905, until June, 1906. For the opportunity to carry on this investigation in a peculiarly stimulating atmosphere, I am deeply indebted to those who administer the affairs of the university. It is an especial pleasure to express appreciation of the constant friendly interest taken by Prof. Duncan S. Johnson. The fundamental teachings of Prof. W. K. Brooks have also molded many of my thoughts and expressions. Thanks are due to Mr. I. F. Lewis for a collection of material from Long Island; to the late Mr. E. R. Heacock for my first pot of prothallia and "sporelings;" to Dr. C. E. Waters for information and for the excellent photographs, plates 1 and 2; to Henry Holt \& Co. for the use of two copyrighted pictures; to Capt. Jehn Donnell Smith for library facilities; to Mr. J. D. Thompson, of the Library of Congress, and Mr. Joseph H. Painter and Mr. W. R. Maxon, of the United States National Museum, for looking up certain papers not otherwise accessible to me; and to the officers of the Academy of Natural Sciences of Philade1phia for the use of several rare old books. All of these obligations are now gratefully acknowledged.

Grinnell, Iowa, April, 1907 .

Henry S. CONARD. 
Digitized by the Internet Archive in 2007 with funding from Microsoft Corporation 


\title{
THE STRUCTURE AND LIFE-HISTORY OF THE HAY-SCENTED FERN.
}

\author{
By Henry Shoemaker Conard, \\ Professor of Botany, Iowa College.
}

\section{HISTORICAL INTRODUCTION.}

The hay-scented fern, Dennstadtia punctilobula (Michx.) Moore (= Dicksonia punctilobula Willd.) first appeared in botanical literature in 1803, when it was described by Michaux as follows:

[Nephrodium] punctilobulum. N. majusculum: stipite nudo, ramis pinnulisque pubescentibus: fronde longa, bipinnata; pinnulis decurrentibus, subovali-oblongis, semi et ultra pinnatifidis; lobulis oblonguisculi, apice 2-4-dentatis, singulis unipunctiferis. Obs.: Habitus Polyp. filicis fœminæ Linn. Hab. in Canada. [A. Michaux, I803, p. 268.]

There is nothing in the text to indicate that this is a new species. Michaux's genus Nephrodium was extremely far-reaching, being defined in these words: "fructibus punctis subreniformibus" (p. 266). Among the species are $N$. thelypteroides, marginale, filix-famina, and dryopteris!

Swartz (1806) placed the hay-scented fern in the genus Aspidium, in which he was followed by Willdenow (1810). The latter writer, both in his own text and in his quotation from Michaux, changes the spelling of the specific name to punctilobum. But he had already (1809) described it under the name of Dicksonia pilosiuscula, and this, too, is copied in the Species Plantarum. The text of the Enumeratio (1809) is as follows:

\section{DICKSONIA.}

Sori subrotundi distincti marginales. Indusium duplex, alterum superficiarum exterius dehiscens, alterum e margine frondis inflexo interius dehiscens.

I. Dicksonia pilosiuscula.

D. frondibus bipinnatis, pinnis pinnatifidis, laciniis dentatis, rachi pilosiuscula. 24 $\mathrm{D}$.

Polypodium pilosiusculum. Mühlenberg in litt. Habitat in Pennsylvania.

An important addition to the other diagnosis is the notice of hairs upon the rachis. These are so characteristic as readily to distinguish this fern from any other in our native flora. In preparing the "Species", Willdenow recognized the similarity of his Aspidium punctilobum and Dicksonia pilosiuscula as expressed in the closing words of the description of the latter:

An Aspidium punctilobum supra p. 270 dubie indicatum, eadem sit filix aliis ad dijudicandum relinquo? quum pinnulæ neque sint decurrentes neque pubescentes. 
Schkuhr (1809, p. 125, plate 131) referred to this fern as Dicksonia bubescens.* He has been followed only by Pres1 (1836, p. 136).

Desvaux (1827) made this species the type and only member of his genus Sitobolium. His diagnosis of the genus reads: "Sori globosi; involucrum fornicatum globulosum a basi ad apicem dehiscens"' (pp. 262, 263). No specific diagnosis is given.t J. Smith (1841) changed the spelling to Sitolobium, and Newman's text (1851) gives Litolobium. G. Kunze writes thus in Linnæa (23:249): Sitobolium (male Sitolobium),"' but in 1848 the printer makes him say "Litolobium (not Sitolobium)." Link's (1841) genus Adectum $\ddagger$ is too late ever to be more than a synonym. The identity of the plant, however, has never been in doubt, for it stands absolutely unique amid its native surroundings. The list of synonymy on page 45 will serve to show how the name has been bowled about.

Its generic affinities are briefly discussed on page 42 . We will simply state that its place is at present established in Bernhardi's (1800) genus Dennstedtia (type: D. flaccida = Trichomanes flaccidum Forst.), and we

*On plate izi marked Dicksonia pubescens. Text on p. 125 reads :

II. Dicks. [pubescens in margin of page] frondibus subtripinnatis, foliolis lanceolatis, pinnis oblongis, laciniis ovatis dentatis, stipite glabro, rachi pubescente. Sw. Mohr. in Litt.

Nephrodium punctilobulum, maiusculum; stipite nudo, ramis pinnulisque pubescentibus: fronde longa, bipinnata; pinnulis decurrentibus, subovali-oblongis, semi et ultra pinnatifidis; lobulis oblongiusculis, apice 2-4-dentatis, singulis unipunctiferis. Mich. Flor. Bor. Amer. II. p. 268.

Habitat in Canada. Habitus Polypod. filic. fem. Mich.

Weichhaariger Dicksonischer Farn. Mit fast 3-mal gefiedertem Laube, lanzetförmigen Blättern, langlichen Blättchen, eyrunden, gezahnten Lappen, glatten Strunke und eine weichhaarigen Spindel.

Dieser Farn erhielt ich stiickweise aus Pennsylvanien auch unter Polypodium pilosiusculum Willd., wonach ich zwar die eigendliche Grösse nicht, aber nach dessen Theilen doch die 3 -fache Fiederung erkennen kann. . . [The next paragraph describes the plate, closing with the words] Alle Rippen der Blättchen and Lappen sind, wie die Spindel, mit gegliederten Haaren bekleidet.

†Desvaux's full text reads : dehiscens.

Sitobolium N. Sori globosi; involucrum fornicatum globulosum a basi ad apicem

I. S. punctilobum N. Nephrodium punctilobum Mich., $\mathrm{Fl}$. am. bor., II, p. 268. Aspid. punctilobum Sw., Syn., p. 6o. Dicksonia pilosiuscula Willd., En. hort. ber., p. 1076. Dickson. pubescens Schk., Fil., t. I31.

$\ddagger$ Link's full text is as follows:

ADECTUM.

Frons tripinnatisecta. Sori subrotundi marginales ad sinus frondis. Indusium undique ad sorum adnatum eumque tegens, demum medio dehiscens et circulare.

A. Dicksonia defectu sporidochii valde differt.

I. A. pilosiusculum fr. tripinnatifida, pinnellis brevibus, antice et superne incisis, stipite rhachi costisque pubescentibus.

$D$. Fr. I-2 ped. alta, pinnae 3 poll. lgae., pinnulae 3 lin. lgae.

Dicksonia pilosiuscula $W . s p .484$. W. E. 1076. E. a. 2.464. H. b. 2.10. Raddi bras. 63. Dicksonia pubescens Schkuhr kr. 125 t. $13^{2}$.

$\mathrm{Hab}$. in sylvis opacis ad rupes Pennsylvaniae et Virginiae nec non in locis montosis prope Tejuco Brisiliae. Perenne. [p. 72.$]$ 
follow Moore (1857) and most recent scholars in accepting the name Dennstadtia punctilobula (Michx.) Moore.

Two varieties of $D$. punctilobula have been described in recent years. Dennstadtia punctilobula var. cristata Maxon (1899) was found in Massachusetts by F. G. Floyd. Under cultivation the percentage of crested fronds produced varies greatly. "Some fronds have not only had the apex of every pinna doubly or trebly crested, but the apex of the frond itself has frequently been bifidly divided with heavily crested apices" (Davenport, 1905). I have several times seen fronds with the rachis bifurcated $10 \mathrm{~cm}$. or more below the apex. Each fork, then, bears a normal continuation of the leaf. Waters (1903) considers this condition "frequent." He also states (p. 289) that "A form with rather narrow fronds, the pinnæ unequal in length and with the teeth of the ultimate segments very deeply cut, so that each vein forms the midrib of a narrow tonguelike segment, has been named $D$. pilosiuscula schizophylla." Of course this name should read Dennstadtia punctilobula schizophylla. On the relation of these varieties to the typical form I have no opinion to express.

In botanical literature other than taxonomic or floristic the hay-scented fern scarcely appears. Descriptions of its habit of growth, its glands, and long, slender rhizome are given by Williamson (1878, p. 117, plates XLV, XlVI), Eaton (1879-1880, pp. 341-343, plate 44), Clute (1901, pp. 225-231), and Waters (1903, pp. 288-290). Frances Wilson writes an appreciative general account of these features in the Asa Gray Bulletin (1897), and Waters (1903) adds to a pleasing text photographs which are exquisite and true to life. Parsons (1899) and Eastman (1904) refer to this fern in a popular way.

Eaton (1879-1880) and Waters (1903) speak of the concentric arrangement of light and dark tissues in the rhizome (cf. fig. 67), and the taxonomic writers tell of the indusium in detail. De Bary (1884) describes the vascular bundle of Dennstadtia (naming this species along with three others in parenthesis) as having a tubular bundle, "which is closed as far as the foliar gap; the bundle which enters the leaf arises from the whole margin of the gap as a continuous concave plate [cf. fig. 82], which is only occasionally split up at its base into several bundles lying side by side." Gwynne-Vaughan in 1901 (p. 85) mentioned the present species as showing thick-walled elements in the phloem of the petiole. In 1903 (p. 691) he includes $D$. punctilobula in a list of nineteen ferns with typical and practically identical solenostelic structure, as described by him in Loxosoma cunninghamii. A page of text is devoted to a summary of the facts of structure in the group. A summary of taxonomic literature, with synonymy, is given on o1r pages 44 and 45 following. 


\section{SPOROPHYTE.}

The hay-scented fern occurs generally in open woods (fig. 1) or clearings or on roadside banks. It prefers well-drained, stony or sandy soil, and ustually forms thick beds. In the Catskill Mountains of New York and in New England it grows on the cleared hillsides in dense patches 8 to $15 \mathrm{~m}$. in diameter. Its range is from New Brunswick to Alabama and Minnesota (Britton and Brown, 1896, 1:12). The leaves are from 50 to 90 $\mathrm{cm}$. high, lanceolate, and thrice pinnatifid. A light-green color and dense pubescence combine to give the fern a soft, feathery appearance. The glandular hairs exhale a delicate fragrance when brushed, which has been likened to new-mown hay; hence the common name.* 'The stems are found 5 to $15 \mathrm{~cm}$. beneath the surface of the soil-long, slender, much-branching rhizomes (fig. 3). These spread rapidly from year to year, and give rise to the densely matted beds of the fern. Roots of threadlike fineness arise plentifully from all parts of the rhizomes and ramify through the soil.

\section{THE ROOT.}

The roots are numerous, cylindrical, with copious, two-ranked branching. They extend more horizontally than vertically in the soil, and do not descend below $20 \mathrm{~cm}$. from the surface. The color is black in mature portions, shading in the younger parts through reddish-brown and brownish-yellow to creamy white at the apex. Although but $0.5 \mathrm{~mm}$. in diameter (maximum $0.545 \mathrm{~mm}$.; minimum $0.49 \mathrm{~mm}$; average $0.523 \mathrm{~mm}$.), they are tough and wiry in texture. The rootlets (secondary roots) are about half as thick as the main roots. Tertiary roots, similar to the secondary, frequently occur. Only rarely does a root arise from the base of a leaf, and then it is usually within $4 \mathrm{~mm}$. of the center of the rhizome.

TABLE 1.-Acropetal development of roots from stem.

\begin{tabular}{|c|c|c|c|}
\hline $\begin{array}{l}\text { Length } \\
\text { of root. }\end{array}$ & $\begin{array}{l}\text { Distance } \\
\text { from apex } \\
\text { of stem. }\end{array}$ & Branching. & Collected. \\
\hline$m m$. & $m m$. & & \\
\hline $4 \cdot 77$ & 3.2 & 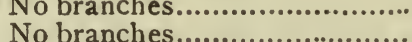 & 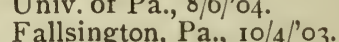 \\
\hline $\begin{array}{l}0.40 \\
3.2\end{array}$ & $\begin{array}{l}3 \cdot 2 \\
4 \cdot 5\end{array}$ & One branch $4.7 \mathrm{~mm}$. long, I & Do. \\
\hline & & cm. from stem. & \\
\hline $4 \cdot 78$ & 6.40 & Many branches.................... & Do. \\
\hline
\end{tabular}

From any part of the stem roots may come out, but more frequently from the lower side. A stem $5 \mathrm{~cm}$. long, including the tip, showed eleven roots, inserted as shown in fig. 9. They arise in acropetal succession very

*The names fine-haired fern, mountain fern, gossamer fern, and hairy Dicksonia are given by Clute (1901, p. 23I), and sweet grass fern by Eastman (1904, p. 67). 
near to the stem apex (see table 1) and lengthen rapidly. I have one which is $24.5 \mathrm{~cm}$. long and the broken ends were frequently found at a distance of $20 \mathrm{~cm}$. from the stem. It is likely that these lengths are not much exceeded. The rootlets are generally alternate on opposite sides of the primary root-axis, but many exceptions occur. Two rootlets are often

TABLE 2.

\begin{tabular}{|c|c|c|c|}
\hline \multicolumn{2}{|c|}{ Root 1.} & \multicolumn{2}{|c|}{ Root 3.} \\
\hline Right. & Left. & Right. & Left. \\
\hline \multicolumn{2}{|c|}{ Stem } & \multicolumn{2}{|c|}{ Stem } \\
\hline 13.5 & & & 13.0 \\
\hline \multirow{2}{*}{ 1. 6} & $3 \cdot 5$ & $3 \cdot 5$ & \\
\hline & 3.2 & 2.0 & 2.0 \\
\hline $3 \cdot 5$ & I. 8 & 32 & I. 5 \\
\hline \multirow{2}{*}{$\begin{array}{l}3.5 \\
3.0\end{array}$} & $3 \cdot 5$ & 3.3 & 3.0 \\
\hline & 1.5 & 4.0 & 6.2 \\
\hline $3 \cdot 3$ & 8.0 & 4.0 & \\
\hline 6.5 & $4 \cdot 5$ & 4.0 & 2.0 \\
\hline \multicolumn{2}{|c|}{ Root 2 . } & 3.0 & 6.5 \\
\hline \multicolumn{2}{|c|}{ (?) } & & 2.0 \\
\hline \multirow[t]{2}{*}{2.5} & $5 \cdot 5$ & 4.0 & 6.0 \\
\hline & 5.0 & 0.5 & \\
\hline I. I & 3.0 & 4.0 & \\
\hline $3 \cdot 3$ & 1 & \multicolumn{2}{|c|}{ Root 4.} \\
\hline $\begin{array}{l}6.5 \\
3.8\end{array}$ & & \multicolumn{2}{|c|}{ (?) } \\
\hline \multirow{3}{*}{ 1. 6} & 5.0 & 2.5 & 25 \\
\hline & 6.5 & 1.8 & \\
\hline & & 3.0 & \\
\hline
\end{tabular}

found consecutively on one side, and in one case five were seen. Successive rootlets may be as much as $8 \mathrm{~mm}$. apart or almost or quite opposite (figs. 6, 7, 8; table 2). None occur usually within 12 or $15 \mathrm{~mm}$. of the stem.

Table 2 shows irregularities in alternate arrangement of rootlets on opposite sides of roots. The figures indicate distance in millimeters of each rootlet from the one next above it, and columns show alternation.

The root-cap is rather long and pointed (fig. 23). From the initial cell of the root outward ten rows of cells may be seen in a strongly developed specimen, five in a slender root of a sporeling. Outside of these cell-layers a worn-out layer is seen, in the act of sloughing off. The inner layers are small-celled and rich in protoplasm. The outermost cells are four times the diameter of the inner, but still nucleated. Indeed, small, dense, nucleolus-like nuclei are seen even in the layer that is shedding. The cap thins out layer by layer along the sides of the root, and the cells become very long and narrow. The outermost layer persists some distance above the next inner one. No sign of statolith bodies has been

seen in any part of the root-cap.

In development, each terminal segment of the root-initial gives rise to a single layer of root-cap cells.* The segment divides first by an anticlinal wall parallel to one of the sides of the initial (figs. 10, 11, 26). In successive cap segments the first wall of one stands either directly over or at an angle of $60^{\circ}$ to that of the preceding or following one, and not at

* In a few cases periclinal walls were seen in three to five or six of the median cells, making the segment two-layered at that point (fig. 24). 
$45^{\circ}$, as stated by Nägeli and Leitgeb $(1868$, p. 76$)$. The halves are next cut into quadrants by anticlinals at right angles to the first wall (figs. 11, $12,25)$. The succeeding walls in the quadrants are heterodromous and may be parallel to either of the preceding or be oblique (figs. 13, 25). No further regularity was found in the division of root-cap segments.

The initial cell of the root is a triangular pyramid with its longest axis in the axis of the root (figs. 23, 27, 28). Lateral segments are cut off around the initial on one side after another in regular order. I noted ten roots (fig. 27) in which the succession of segments was counter-clockwise (proceeding from older to younger segments) and four in which it was clockwise, as one views the cell from its outer (capward) base. Each lateral segment divides first by a periclinal wall near its outer margin (figs. 14, 15, 23, 27-29). The next wall is a radial anticline which passes inward from near the middle of the first, and strikes one of the sides of the segment near its inner angle, dividing the inner cell into "sextants" (fig. 16, II; segment 3 in figs. 27-29). Thus there is in each segment a larger (major) and a smaller (minor) sextant. In transverse section of the root we see the three major sextants meeting at the center of the section (figs. 29-33), with three alternating minor sextants which do not reach quite to the center. The "sextant wall" meets that side of the segment which is adjacent to the next older segments, (kathodic wall) and is therefore katadromous. As all of the segments in any root are alike in this respect, the divisions are said to be homodromous. Soon after the sextant wall is formed in the inner part of the segment it is laid down also in the outer part (fig. 17; segment 4 in figs. 27-29).

A second pericline is now laid down near the middle of each inner sextant cell (figs. 18, 23; segment 5 in figs. 27-30). As this wall forms the boundary between the plerome and outer tissues, it may be called the periplerome wall. Another periclinal laid down in the two outer sexants divides these into two layers, the definitive epidermis (piliferous layer) and hypodermis (fig. 19; segment 6 in figs. 27-31). Both of these tissues remain one-layered throughout. Subsequent divisions in them are all anticlinal, either radial or transverse (figs. 23; 27-33). A1most simultaneously periclinal walls are formed on each side of the periplerome wall, near and parallel to it (figs. 14, 20, 21, walls vi and vir; 23). In the majority of cases, however, the outer one seems to precede. The resulting cells constitute the definitive endodermis and pericycle. The cells of the former are from the beginning flattened, of the latter nearly cubical (figs. 23, 31, 33).

If we group the segments into cycles of three, beginning with the latest formed ( $c f$. figs. 27, 28), we find walls I and II (figs. 14-22) already in one or more of the youngest cycle. Walls II, III, and IV are found in the second cycle, and VI and VII in the second or third. In the second or 
third cycle of segments longitudinal radial anticlines are also formed in the outer members of the segment, dividing the sextants into halves (figs. 21,22 , VIII). As yet each segment consists of but one layer of cells. Transverse anticlines occurring throughout the segment in the third or fourth cycle make it two-layered (fig. 23). A second series of divisions in the same plane cuts the outer tissues (epidermis, hypodermis, cortex) into four vertical layers. These cleavages occur first in the epidermis, but their order of sequence is rapid and apparently varied. The pericycle is late in becoming divided; and the endodermis of a certain pair of opposite sextants lacks the radial division for a long time, as will be described in speaking of the origin of lateral rootlets.

The large cell remaining between the endodermis and hypodermis (figs. $14,20,21,23)$ gives rise to all of the cortex. After its transverse anticlinal division it rapidty undergoes one to three periclinal and as many radial divisions. The periclinals probably take place in centrifugal order. The result is a cortex of two to four concentric layers, each with 14 to 24 cells. The last divisions are complete in the fourth, or at least the fifth cycle of segments ( $f$. figs. 28-33).

The triangular cells lying within the pericycle (fig. 21) divide either by a periclinal wall into two parts or by two tangential walls into three parts (figs. 22, 29-31). The tips of the three major sextants and of one minor (occasionally two) become tracheids of the metaxylem. The cells between the tracheids and the pericycle of this minor and of the major opposite to it become protoxylem cells (figs. 14, 22, 29-33); the intermediate parts of the other two majors, and all within the pericycle in the two remaining minors (with the exception noted above) go to form phloem (figs. 14, 22, 29-33).

As the elements elongate, the transverse limits of the segments are soon obliterated (fig. 23). Four or at most five cycles only can be recognized. The sextants, however, may often be distinguished until quite a late period (fig. 33).

The above-described order of the early divisions of the segment (walls I to vII, figs. 14-22) is easily followed in its main outlines in good serial sections of any leptosporangiate fern root. But English and German text-books* still adhere unanimously to the statement of Nägeli and Leitgeb that the first division in the segment is the sextant wall, followed by that which separates periblem and plerome. The first error was corrected by Lachmann (1885; 1887; fide Van Tieghem and Douliot), and

*Nägeli and Leitgeb, 1865, 1868; Pteris hastata, plate 14 , fig. 7 .

Sachs, 1875, pp. 124-125, fig. 102A.

De Bary, 1884, pp. 18-19, figs. 7A, $8 \mathrm{~A}$.

Goebel, 1887, pp. 214-215, fig. 162.

Bower, 1889.

Vines, 1894, pp. 149-1 50, figs. I I 4 , I 15.
Campbell, I 895, p. 328-329, fig. 165A ; 1905 p. 333 .

Strasburger, I 897, pp. 3 I I-313, figs. I 39, 140.

Sadebeck, I8g8, p. 6I, fig. 4 I A.

Strasburger, Noll, etc., I898, pp. I50-I 5 I, fig. 165 .

Haberlandt, 1904, p. 74, fig. I4. 
the second by Van Teighem and Douliot in 1888. The latter authorities indicate that in some ferns (Pteris, Adiantum, Aneimia, etc.) the outer cell (figs. 14, 16, 17) may give rise to two or three layers of cortex in addition to the epidermis (see table of cell-lineage in fern roots, p. 46). Such ferns are in the minority. The same writers state that in Equisetum, Osmunda, and Todea the first periclinal wall is between the central cylinder and cortex, but that this is not the case in any other Pteridophytes which have a single initial in the root.

I have found the account here given for Dennstadtia as to the origin of epidermis, hypodermis, cortex, and endodermis to apply equally to root-tips of Cibotium regale, Aspidium molle (fig. 48), Lygodium japonicum, Onoclea sensibilis (fig. 51), Ceratopteris thalictroides (fig. 50), and Aspidium marginale (fig. 47). In Pteridium aquilinum and Didymochlena lunulata (fig. 49) the epidermis and two layers of cortex are derived from the same part of the segment.

Above the region of cell division in the root-tip there intervenes a brief region of elongation. Beyond this, viz, about $2.5 \mathrm{~mm}$. from the apex, root-hairs appear. Each hair is a cylindrical outgrowth from the lower (distal) end of an epidermal cell. The cavities of cell and hair are continuous, and contain but one nucleus (fig. 252) lying variously in the wall-layer of protoplasm. In functional hairs the nucleus is seen near the swollen apex. The walls of the hairs are thin, of a clear, brownish-yellow color, and are often molded around irregular particles of earth. Table 3 gives the exact dimensions.

A transverse section of the region of functional root-hairs (figs. 34, 35, 44) shows the epidermis, hypodermis, four or five (rarely three) layers of cortex and a well-defined endodermis. A single layer (rarely doubled in places) of pericycle surrounds the cylindrical, diarch bundle. Protoxylems abut directly upon the pericycle at diametrically opposite points, and between them lies a group of two to four (rarely five) large tracheids. Extending around within the pericycle from each side of each protoxylem is a row of three to seven sieve-tubes. Midway between the protoxylems and lying against the pericycle is the small-celled, dense protophloem. Between the phloem and xylem are cells of conjunctive parenchyma.

The epidermis (piliferous layer of Van Tieghem, etc.) at the level we are speaking of is fully mature, and consists of cells four to six times as long as wide. In cross-section they are nearly isodiametric, of slightly variable depth and width, and bulging out a little on the outer side. The 
walls are brownish-yellow, like those of all of the cells outside of the endodermis. The subjacent hypodermal cells are about three times as wide and twice as deep radially as those of the epidermis, and similarly elongated. The first cortical layer is composed of cells nearly twice as large in cross-section as the foregoing, but like the last in length and character of wall. Intercellular spaces occur rarely at the angles of these cells. The cells of the second cortical layer are smaller again, often as narrow as the epidermal cells. The two innermost layers are still smaller. In the last three layers, especially the middle one, thickening of the walls begins even before the root hairs are fully mature (fig. 43). At this stage the endodermal cells are already very long, narrow, and practically empty. Pericycle and conjunctive parenchyma are full of dense, granular contents. They are probably multinucleate, since the cells are very narrow and long, but nearly always show a nucleus in cross-sections. The pericycle cells are often much larger in the region of the protophloem than elsewhere (fig. 35). The protophloems have already passed their greatest density and prominence and the sieve-tubes now appear mature. Each protoxylem consists of one or two extremely slender spiral elements, with one or two slightly wider scalariform tracheids on either side. The two or four large central tracheids of the metaxylem show as yet no thickening of the walls (figs. 34, 35, 36, 43, 44).

TABLE 4.-Statistics of transverse section of root.

\begin{tabular}{|c|c|c|c|c|c|c|}
\hline \multicolumn{2}{|c|}{ No. of cells in- } & \multicolumn{3}{|c|}{ Cortex. } & \multicolumn{2}{|c|}{ No. of cells in- } \\
\hline Epiderm. & Hypoderm. & $\begin{array}{l}\text { No. of } \\
\text { layers. }\end{array}$ & $\begin{array}{l}\text { No. of cells } \\
\text { in outer } \\
\text { layer. }\end{array}$ & $\begin{array}{c}\text { No. of cells } \\
\text { in inner } \\
\text { layer. }\end{array}$ & Endoderm. & Pericycle. \\
\hline 64 & 30 & 4 & *22 & 20 & 19 & 2 I \\
\hline 49 & 19 & 4 & 14 & 24 & 18 & 20 \\
\hline 40 & 17 & 4 & ... & $\ldots$ & $\ldots$ & $\ldots$ \\
\hline 40 & 20 & 4 & 14 & 23 & 16 & 17 \\
\hline 46 & 26 & $\ldots$ & *18 & 13 & 10 & 13 \\
\hline+61 & 27 & ... & 22 & 20 & 15 & 19 \\
\hline+52 & 28 & 4 or 5 & $\ldots$ & 21 & 15 & 20 \\
\hline t5o & 26 & $\begin{array}{r}\text { I with } 3 \\
\text { 1 } 4 \text { with } 4 \\
\text { 10 with } 5 \\
3 \text { with } 6\end{array}$ & 21 & I7 & 13 & 16 \\
\hline
\end{tabular}

* Immature.

† Sections of one root, $16 \mu$ apart.

Following all these parts upward in an old root, we find that the epidermis and outer soft layer of cortex wither after the root-hairs die, and are ultimately sloughed off (fig. 46). The bundle is now protected by the two or three inner cortical layers, whose walls have thickened so as almost to obliterate the lumen. Lignification in the metaxylem takes place slowly. In a section showing a withering epidermis, and the inner cortex indurated 
so that the cell-walls are about one-fourth the width of the lumens, there are (fig. 44) two large tracheids slightly thickened, and two in the center wholly unthickened and containing protoplasm. Only with the decay and disruption of the outer layers of the root do the inner cortex and xylem become fully mature (fig. 45). This occurs from $3.5 \mathrm{~cm}$. to $10 \mathrm{~cm}$. from the root tip. One can not as a rule, obtain a transverse section showing all of the tissues mature and intact.

These facts have an important physiological significance. We suppose the water-supply of the plant to come in through the root-hairs. But where these are functional the xylem, always considered the water-conducting tissue, is decidedly immature. It is evident that lignified walls are not necessary for the conduction of water in the cells. It may be, however, that the inner cortex, whose walls thicken at such an early period, is for a time active in water conduction.

In 25 out of 95 roots examined (i.e., 26.3 per cent) from localities in Long Island, Pennsylvania, and Maryland, a more or less copious growth of non-septate fungus hyphæ was found in the middle cortex (figs. 52, 53). One of the most pronounced cases was attached to a rhizome of unusual thickness and width and with an unusually long and rapidly growing meristematic apex. In a root-tip from this plant, hyphæ were seen $3.07 \mathrm{~mm}$. from the initial cell. They were located in the epidermis and hypodermis, with branches running inward. In an older root, a hypha was seen extending into the root through a root-hair (fig. 53). Once in the middle cortex, strong hyphæ run from cell to cell, ramifying in each cell to form a dense granular mass (fig. 53). Sometimes the fungus is found only on one side of the root, or in only a few cells. Occasionally it spreads all the way round. From the undoubted vigor of the host where the fungus occurs, the early stage of the root at which it appears, and the mode of copious branching of the hyphæ in the medio-cortex, we feel justified in considering that we have to do with a true mycorhiza. On account of its inconstancy, it may be called facultative. No other polypodiaceous fern is known to possess such a commensalism, though Janse (1895) has recorded a similar condition in the acrial roots of Cyathea (species not given).

Lateral rootlets arise from rhizogenous cells of the endodermis, opposite the xylem rays, as is universal in ferns. The endodermis has been shown (p. 10) to originate in the root apex with two cells in each segment, i. e., one in each sextant. After the segment is divided transversely into two layers, there are two endodermal cells to a sextant, one 1ying nearer the apex than the other. In the two opposite sextants in which the protoxylems are later to form, the endodermal cell lying nearer the root apex remains undivided by any radial walls, while its posterior and sister cell, like all the other endodermal cells of the root, is halved radially. This large cell, extending clear across the sextant, is the primitive rhizogenous 
cell (figs. 32, 33, 34). On one side it lies in a major sextant, on the other side in a minor; but both of these sextants remain much narrower than the other four (figs. 32, 33), as if to accommodate this undivided cell. As the root elongates in this region, transverse divisions take place in the rhizogenous cell. The more distal member in each case retains its identity, while the others sooner or later divide radially and become like ordinary endodermal cells (figs. 38-40). If the radial walls are slow to appear, we may have a row of three or four equally broad cells (figs. 38-40), of which only the most distal is rhizogenous. In Cyatheacer all of the cells in the same vertical line with the rhizogenous cell are said to be of the same width as the latter (e. g., Cibotium regale; $f f$. Sadebeck 1898, p. 63). Dennstcedtia, therefore, agrees with Polypodiaceæ in this respect.

After elongation of the root is complete, the definitive rhizogenous cell swells out into a lens-shaped body (fig. 34). On its proximal side it is cut once more by a transverse wall, but this wall passes obliquely inward (fig. 37). Two obliquely longitudinal walls follow (figs. 35, 36, 40, 41) hewing out a tetrahedral cell with one face against the cortex, one side toward the stem, and the apex toward the subjacent pericycle. This is the rootlet initial (figs. 36, 40, 41), and the three cells which bound its sides are the first segments of the rootlets. This initial and all of its segments proceed to develop as in the case of the parent root (figs. 41-43). The rootlet being smaller than the root (fig. 54), its segments undergo fewer divisions in the cortical region. The xylem of the rootlet stands transversely to that of the root. Therefore the protoxylems are to the right and left if the root is held in a vertical position, and the xylem band of the rootlet will lie horizontally. The xylems of the rootlet arise in the second and third (and overlying) segments formed from the rootlet-initial, and in their proximal sextants.

Meanwhile divisions have also occurred (as shown by mitotic figures) in the neighboring endodermal and cortical cells. In the former no regularity was observed. The cortex, however, develops a mass of small protoplasmic cells directly over the rootlet (figs. 34, 42, 43) and undergoes no induration here. The cells immediately adjacent to the root-cap are finally organized into a special layer (fig. 43) which advances through the remaining cortex, etc., apparently causing the disintegration and absorption of these tissues. In the mature stage all of the tissues of root and rootlet, excepting epidermis and outer cortex (including hypodermis), are respectively continuous. Certain inner cortical cells of the main root bend out into the branch, but endodermis and pericycle (fig. 55) connect by the intervention of a number of cubical cells. The xylem tracheids of the branch terminate abruptly against the side of those of the main root and at right angles to them (figs. 56, 57). The phloems connect in a manner similar to the xylems. The mature rootlet repeats the structure of an ordinary root on a smaller scale (fig. 54). In a slender rootlet there may 
be but two layers of true cortex between endodermis and hypodermis. In this case the outer layer has six large cells in a circle, and the inner layer and hypodermis have twelve cells each. The sextant walls of the apex thus persist, and may even at times be traced through the endodermis and pericycle. Plainly this does not in any sense indicate a common origin of endodermis and pericycle.

In relation to the stem, the main root originates very near the apex, in that layer of cells which will subsequently give rise to both endodermis and pericycle (fig. 70). The rhizogenous cell is large and cubical. By three oblique walls a tetrahedral initial is early cut out, and from this time onward it behaves just as it would in a mature root. It has no fixed position in relation to the stem-initial. Beneath (centrad) the developing root-tissues a great proliferation of stem-tissue takes place. The root is thus borne halfway through the cortex, or farther, on a "pedicel" (figs. 59-61) while it is of itself digesting away the outer cortex and forming a many-layered cap. It finally emerges through a ragged opening in the cauline cortex (fig. 102).

During the elongation of the stem the vascular tissues connecting root and stem are much deformed, with the following result: Tracing the mature root inward, its stele passes obliquely half-way through the cortex of the stem (fig. 102), then bends sharply backward, and fuses with the stem stele. The cortex, endodermis, and pericycle of both organs are smoothly continuous. But the root-xylem, after passing a little backward, turns at an acute angle forward for a short distance. Some elements become at once cauline, and run on forward. Others, by another sharp bend, turn ,backward in joining the xylem of the stem. Rarely a tracheid runs directly from the root into the stem without a double bend. Phloem and conjunctive parenchyma follow parallel with the xylem. The depth of these bends varies. In any case, those tracheids which are continuous from root to stem must assume very peculiar shapes (figs. 58, 61, 62). The bending occurs at an early stage of the development, before the cells become lignified (fig. 61). When a root originates from a leaf-base it passes out in a similar manner. A double bend occurs in the vascular elements, but the folds are quite shallow.

\section{THE STEM.}

The rhizome is slender and cylindrical and more or less branched (fig. 3). A piece in my collection from Bucks County, Pennsylvania, grown in loose loam, is $35 \mathrm{~cm}$. long, with branches $15 \mathrm{~cm}$. and $4 \mathrm{~cm}$. long. Another rhizome from Delaware County, Pennsylvania, is $8 \mathrm{~cm}$. long to a fork; one branch runs $23.5 \mathrm{~cm}$. and forks into parts $4.5 \mathrm{~cm}$. and $3 \mathrm{~cm}$. long, respectively; the other branch runs $19.5 \mathrm{~cm}$. to a fork, with the parts $22 \mathrm{~cm}$. and $13 \mathrm{~cm}$. long. The diameter varies from $1.5 \mathrm{~mm}$. to $4 \mathrm{~mm}$., with a mean of about $3 \mathrm{~mm}$. When fresh the rhizomes are somewhat flexible, but the 
cortex readily breaks across and pulls loose from the much more tough and elastic vascular core. The outer surface is of a dark reddish-brown color, shading to nearly white at the apices. In very rapidly growing rhizomes the soft white apical region may be $2 \mathrm{~cm}$. long, but usually it is about $5 \mathrm{~mm}$. Glabrous to the unaided eye, the mature parts of the rhizome may be seen with a hand lens to be scattered over with the bases of dead hairs. At the apex the hairs themselves are very numerous and serve to clothe the soft parts with an efficient protective covering (figs. 70, 106). Scales are entirely lacking from all parts of the plant.

The leaves are inserted without articulation, mostly alternately to right and left of the mid-line on the dorsal surface of the rhizome. They stand therefore in two dorso-lateral rows.* Since the distances between them range from $1.6 \mathrm{~cm}$. to $5.7 \mathrm{~cm}$. (usually about $3 \mathrm{~cm}$.), we may speak of definite nodes and internodes (fig. 3) ( $c$. Boodle, and Gwynne-Vaughan).

Branching occurs in two ways: direct forking of the rhizome, and occasional stem-buds given off from the lower parts of the petioles (figs. 3, 4). The latter will be discussed in connection with the leaf. A fork gives all the appearance of a true dichotomy, the two branches spread equally, like the arms of a $\mathrm{Y}$, from the parent axis, and a ridge runs over the crotch (fig. 99) from dorsal to ventral surface of the stem. In young stages (arms 1 to $2 \mathrm{~cm}$. long) the two branches are alike in length and diameter, but inequalities of growth soon cause them to differ. I did not determine how the two initial cells originate.

The interesting and beautiful concentric structure of the stem (fig. 67) was evidently known to De Bary $(1877,1884)$, and was thus described by Eaton (1879):

The section shows a broad exterior ring of light-brown parenchyma; inside of this is a broad circle of minute white starch-cells, then scalariform vessels in a narrow ring, bordered by other minute cells, which are most probably bast cells; inside of this is another broad circle of starch-cells and in the very center is a roundish mass of brown sclerenchyma. The whole section has such a regular concentric system that it is not only very pretty to look at, but would be very well suited for anatomical study in the classroom [p. 341].

Gwynne-Vaughan (1903) also says:

A perfectly solenostelic vascular system was found in the stems of all the species included in the following list: Davallia hirsuta, marginalis, strigosa, platyphylla, hirta, spelunca, nova-zeylandia, Lindsaya retusa, Dicksonia apiifolia, cicutaria, scabra, punctiloba, davallioides, Pteris scaberula, incisa, ludens, Pellaca atropurpurea, falcata, Jamesonia imbricata. All these ferns have a creeping, more or less dorsiventral rhizome, with the leaves arranged in two rows on the upper surface, and their solenosteles differ from each other and from that of Loxosoma as described in Part I of this paper [1901] in so slight a degree that the same description will serve for them all [p. 69r].

* Of 134 leaf-bases on stems which were taken at random, 96 insertions were dorsolateral (right or left), 21 directly on one side (right or left), 16 dorsal, and 3 ventral. Each ventral leaf springs from the angle of a fork of the stem, and bends upward through the fork. 
In the mature internode (figs. 63, 64, 67, 97) we find externally an irregular black, sclerosed epidermis (see table of measurements p. 19). The inner walls often bear rod-like thickenings projecting into the lumen of the underlying cells (fig. 63). Next within comes a broad zone of blackwalled sclerotic cortex, ten to twelve cells deep. These cells (fig. 63, s) are angular and do not inclose intercellular spaces. Although mostly appearing empty, they may contain considerable amounts of starch, especially in the inner members. They are largest in the middle of the zone. There are pores of different sizes and shapes irregularly scattered over the walls. The ends of the cells are oblique or bluntly tapering (fig. 64; see table, p. 19).

Sharply demarcated from the sclerotic cortex by a sudden change in the character of the wall is a narrow layer of starchy cortex (figs. 63, 64, st.). This layer is from three to eight cells thick. The cell-walls are thin and colorless. They inclose protoplasm and nucleus, and are densely packed with starch. Intercellular spaces are easily perceptible here between the rounded cells. The end walls are transverse or are slightly oblique (see table, p. 19).

The cortex is bounded on its inner side by a continuous sheath of endodermis - a circle, in cross-section, of flattened but irregular cells, very poor in contents (figs. 63, 64, 67, 97). Each radial wall bears a thickened band which stains with safranin (see table, p. 19).

Within this layer intercellular spaces can be no longer found, but we encounter a thick ring of vascular tissue, which again incloses a rod-like core of starchy and sclerotic cells (medulla). In short, the vascular system constitutes a cylindrical tube. The vascular ring itself shows, passing, from without inward, successive rings of-
(I) Endodermis.
(7) Inner conjunctive parenchyma.
(2) Pericycle.
(8) Inner phloem.
(3) Protophloem.
(9) Inner protophloem.
(4) Phloem.
(5) Conjunctive parenchyma.
(6) Xylem.
(ro) Inner pericycle.
(II) Inner endodermis.

In the words of Gwynne-Vaughan (1903):

The xylem ring is surrounded both externally and internally by a complete ring of phloem and pericycle, and the whole is delimited from the ground tissue on both sides by a well-marked endodermis.

The outer pericycle (fig. 63) consists of two or three layers of angular cells, densely packed with starch. Their walls tend to lie in radial and tangential planes, and the radial walls are often in continuity with those of the endodermis (see table, p. 19).

Protophloem is difficultly discernible in the old stem, though it forms an almost continuous ring of cells. The elements are greatly elongated, very slender, angular, of various shapes and sizes, with finely tapering ends. 
Only rarely do two elements lie adjacent radially. The walls are thick, but not lignified, and are beset with deep pits with rounded, flaring apertures. They are best seen in the very young regions (figs. 107, 110) where lignification is just beginning to occur in the xylem (see table below).

The phloem forms a continuous ring, one to three cells in thickness. The cells are angular and appear in cross-section to be empty; their ends (fig. 65) acute, but not finely tapering. These are sieve-tubes, but the sieve-plates are only found with some difficulty. I could not demonstrate callus, either with azoblue or coralline soda.

TABLE 5.-Measurements in millimeters of cells of various tissues in the stem.

\begin{tabular}{|c|c|c|c|c|c|c|c|c|c|}
\hline \multirow{2}{*}{ Tissue } & \multicolumn{3}{|c|}{ Length. } & \multicolumn{3}{|c|}{ Radial diameter. } & \multicolumn{3}{|c|}{ Tangential diameter. } \\
\hline & Aver. & Max. & Min. & Aver. & Max. & Min. & Aver. & Max. & Min. \\
\hline $\begin{array}{l}\text { Epidermis............... } \\
\text { Outer sclerotic cor- }\end{array}$ & 0.1 & 0.16 & 0.064 & 0.02 & 0.03 & 0.014 & 0.035 & 0.0372 & 0.032 \\
\hline 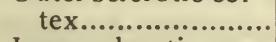 & .264 & & & .037 & .047 & .032 & & & \\
\hline 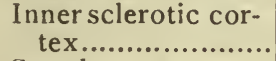 & $\cdot 33^{6}$ & .44 & .21 & $.05 \mathrm{I}$ & .066 & .032 & & & \\
\hline Starchy cortex........ & .142 & .246 & .088 & .042 & .05 & .032 & ............. & .......... & ..... \\
\hline Outer endodermis... & $.06_{3}$ & .078 & .057 & .00825 & .009 & .00714 & .0195 & .0214 & .014 \\
\hline Outer pericycle....... & .01447 & .16 & .127 & -.0157 & .0178 & .014 & .0239 & .032 & .0178 \\
\hline Outer protophloem.. & .678 & .......... & ........... & .00892 & ............ & .............. & ............. & (n........ & (............ \\
\hline $\begin{array}{l}\text { Outer phloem.......... } \\
\text { Outer conjunctive }\end{array}$ & anc........ & 2.1 & 1.5 & .0164 & .025 & .013 & & (.......... & (n.......... \\
\hline parenchy ma........ & .167 & .......... & & .0127 & .......... & .............. & & & \\
\hline Xylem....................... & (n........... & $4 \cdot 4$ & I. 6 & .06 & .078 & .032 & .04 & .057 & .02 \\
\hline Inner phloem........... & ............. & n......... & .......... & .0155 & $.02 \mathrm{I}$ & .0134 & n........... & (n........ & (n.......... \\
\hline Inner endodermis... & .099 & .149 & .082 & .0083 & .014 & .0071 & .01985 & .022 & $.017^{8}$ \\
\hline Starchy medulla..... & .166 & .264 & .105 & .034 & .039 & .025 & (............ & ............ & ............. \\
\hline
\end{tabular}

Between phloem and xylem lie the thin-walled, angular, starch-laden cells of conjunctive parenchyma (figs. 63, 64, 81). They are about twelve times as long as wide, and have tranverse or oblique end-walls. Some of these cells may extend in between the xylem tracheids, and rarely such an extension joins with the inner conjunctive parenchyma, completely interrupting the xylem. Sometimes the conjunctive parenchyma is interrupted and a sieve-tube lies directly against a scalariform tracheid.

With the above exception the xylem is a continuous ring of larger and smaller scalariform tracheids, with thick, lignified walls (figs. 63, 67, 97). The middle lamella is clearly discernible. In places this ring includes but one radially widened xylem element; in other places it may be three cells thick. There are no spiral elements in the stem. The tracheids are of the usual long, pointed type (figs. 78, 79; see table above).

The inner tissues so closely resemble the outer that they may be described simply by comparison (figs. 63, 64). Conjunctive parenchymas show no difference. The inner phloem is mostly one, often two, cells thick, and the sieve-tubes are narrower than the outer ones (see table above). Proto- 
phloems present no differences. The inner pericycle is one to two, rarely three, cells thick. Inner endodermis is like the outer in cross-sections, but seems to have longer cells (see table, p. 19).

The layer of starchy medulla inside the vascular ring corresponds with that on the outside. In a rhizome with six to eight layers outside, there are about seven inside. In another with three or four (mostly three) layers outside, there are two or three (mostly three) inside. But the inner cells are smaller than the outer (see table, p. 19). The inner sclerenchyma cells (sclerotic medulla) are longer and narrower than the outer, and have thicker and blacker walls (figs. 63, 64, 76, 77, 80). They form a core from twelve to twenty-two cells in diameter.

The above type of stem is called by Gwynne-Vaughan (1901) a solenostele (adj. solenostelic) and by Jeffrey (1897) an amphiphloic siphonostele. The description may serve as a definition of these terms.

At the node (figs. 3, 4, 66) the cylindrical leaf-base springs from the slightly larger stem at a right or acute angle, usually without altering the size or shape of the stem. Occasionally the stem is slightly enlarged below the node, and rarely there is a slightly prominent ridge between leaf and stem, as at a fork.

The leaf-trace or vascular bundle of the leaf (petiolar meristele) leaves the stem as a trough-like band (horseshoe-shaped in transverse section) which is of the same thickness as the wall of the vascular tube of the stem (fig. 82). The concavity of the trough faces obliquely upward and forward in most leaves. But where the leaf-insertion is ventral (figs. 83-87) or lateral the trace faces directly upward. When the insertion is dorsal the trace faces directly forward. At the place where the leaf-trace leaves the tubular vascular system of the stem a distinct leaf-gap occurs (fig. 82). This is a narrow slit in the stem bundle, through which the medullary and cortical tissues become continuous. The gaps differ in shape and in their exact relation to the leaf-trace. One gap is $11 \mathrm{~mm}$. long and $1.2 \mathrm{~mm}$. wide, with acute ends, and with the leaf-trace attached near the middle of the ventral side. Another is $14 \mathrm{~mm}$. by $1 \mathrm{~mm}$. A third is $1.8 \mathrm{~mm}$. by $0.3 \mathrm{~mm}$., rounded at both ends, with the leaf-trace occupying nearly all of one side. The average size (of ten) is $5.45 \mathrm{~mm}$. long and $0.53 \mathrm{~mm}$. wide. Usually the anterior end is rounded and the posterior end tapering and acute, with the leaf-trace attached along one side, at or near the anterior end. Such a gap is figured by Gwynne-Vaughan (1903, plate 33, fig. 1). When the leaf-insertion is dorsal the trace arises symmetrically from the rounded posterior end of the gap. Lateral leaf-traces differ scarcely at all in their origin from the usual dorso-lateral type. Ventral leaves, springing from a fork, are symmetrically attached to each arm of the stem (figs. 83-87). The trace lies like a trough with its concavity upward. Approaching such a nodal fork along the main stem, the stele first becomes wide and flat. Then a slit is found on the upper side, and as the branches 
separate this slit forms a leaf-gap in the adjacent (inner) face of each branch. From the lower margin of both gaps the trough-like leaf-trace comes off, forming for a time a connection across the fork from one branch to the other. It soon becomes distinct from both. Leaf-gaps are easily dissected out, since the tissues readily separate along the line of the endodermis.

As stated above, the cortex and medulla of the stem come into contact or continuity through the leaf-gap (fig. 100). The starchy layers always connect, and sometimes a strand of sclerotic cells connects the outer cortex with the similar central medulla. In about half the nodes examined ( 9 out of 20) the sclerotic medulla passes the leaf-gap as a solid rod unchanged. In one-fifth (4) it connects directly with the outer cortex through the wide leaf-gaps. In 7 a rod of sclerenchyma passes from the medulla outward in the groove of the leaf-trace to vanish in the petiole or to become continuous there with a peripheral layer of similar cells. This rod may originate independently in the starchy medulla shortly below the node, or it may begin as a ridge on the sclerotic medulla, which is gradually constricted off. These different arrangements of sclerenchyma may occur at successive nodes of one stem.

Between the cortex and the xylem of the stem, all of the inner and outer tissues become continuous around the margins of the leaf-gap-endodermis with endodermis, pericycle with pericycle, phloem with phloem, and conjunctive parenchyma with conjunctive parenchyma (fig. 108). Or, the phloem may become very thin, or may be completely interrupted for a short distance on one or other side of the gap. A transverse section of the stem through a leaf-gap shows the vascular system as a deep, round horseshoe (fig. 100). No new tissue elements are seen at the nodes. Spiral vessels are not found in leaf-trace or stem. The cells bend out from stem to leaf by gentle curves, without any noticeable peculiarities.

Where the stem forks each tissue system remains continuous and unbroken (fig. 99). There is no ramular gap. One can best imagine the structure by starting with a $Y$-shaped object made of round rods, welded together below. Let this represent the sclerotic medulla. We dip the object into melted wax, coating it all over; this represents the layer of starchy medulla. Suçcessive coatings of suitable thickness may represent inner endodermis, inner pericycle, inner phloem, xylem, outer phloem, outer pericycle, outer endodermis, starchy cortex, sclerotic cortex, and epidermis. In the angle of the $Y$ the continuity of tissues from one arm to the other is strikingly smooth and regular. A single scalariform tracheid may extend for a long distance in each arm. On the sides of the fork this continuity involves angular elements of peculiar shapes (fig. 98).

The apex of the stem is so clothed with hairs as to appear smoothly rounded (fig. 3). Under this covering there is a shallow, basin-like depression (fig. 70), not often symmetrical, at the tip of the stem. A low 
protuberance standing out in the center of this basin is the growing point. Its surface is naked and is rendered irregular by leaf-rudiments. At the top of the protuberance is the stem-initial-a narrow, irregularly triangular cell. In longitudinal section it is deeper $(0.0642 \mathrm{~mm}$. to $0.07 \mathrm{~mm}$.) than any other cell, excepting a newly formed segment (figs. 106, 129). But in cross-scetion it is smaller than many of its near neighbors (figs. 71, 103, 109). This narrowness makes it difficult to recognize. Further, as the protuberance in which it stands varies in apparent position according to the development of the young leaves, one can not be sure of getting satisfactory sections of it by cutting a bit of stem in an exactly transverse or longitudinal plane.

Segments are cut off in regular succession on the three interior faces of the initial. As I could not, even with much effort, distinguish any regular position of the initial with regard to dorsal and ventral surfaces of the stem, we can not speak of dorsal or ventral segments. The irregular arrangement of the leaves is probably related to this irregularity of the position of the stem-initial. The order in which the segments are cut off is either from left to right or right to left, the two occurring in about equal numbers in my preparations (7 counter-clockwise, 5 clockwise, from older to younger).

Each segment is divided first by a periclinal wall near its inner end. The small, deep-lying cell thus formed gives rise to the medulla (fig. 106). The outer cell is next cut by the sextant wall-a radial anticline, dividing the cell nearly into halves ("sextants"). This wall remains prominent for a comparatively long time (figs. 71-75, 103, 109) ( $c f$. Bower's figures, 1889). The relative sequence of the following anticlines and periclines was not determined. The second periclinal wall is formed near the inner end of the columnar partial segment or sextant, giving an inner nearly cubical cell and an outer columnar one (fig. 106). The inner of these (plerome rudiment) gives rise to the vascular system of the stem, including outer and inner endodermis. The sextants are usually halved longitudinally at right angles to the sextant wall (fig. 73), and as many as sixteen to twenty rectangular cells may be formed by walls at right angles to the two just mentioned (figs. 75, 103). Very often oblique walls break up the symmetry. The outer cells are repeatedly divided by periclines near the inner end (fig. 106) until, after four or five such partitions, the remaining outer portion is reduced to the depth of the epidermis. Division then ceases. Meanwhile the whole segment has been pushed farther and farther from the growing point of the stem. The last pericline occurs in cells which are nearly half-way up on the sides of the basin-like depression of the stem apex.

Near the lowest part of this depression arise the hairs which clothe the apex (fig. 106). A superficial cell bulges out slightly and is cut obliquely. The outer member enlarges in length and diameter, and is divided by several septa. These divisions are often intercalary. The two basal cells 
also straighten up their originally oblique wall, until it stands perpendicular to the surface of the stem. Thus there results a basal cell of a hair, with a hairless sister-cell beside it. A similar development of protective ramentum was described by the writer on the stem-tip of Nymphæa.

Returning to the plerome rudiment, it develops much more slowly than the cortex. It divides periclinally into two equal parts (fig. 106) and each of these again by similar walls, giving four layers of cells in the plerome. Apparently the outermost and innermost of these give rise to pericycle and endodermis, while the two median probably produce xylem and phloem. Certain it is that all the tissues just named come from the four cells in question. It is also certain that the endodermis is formed at the last periclinical division in the outermost layer of plerome, and each endodermal element is a sister cell to the pericyclic cell radially next to it. This has been suspected by several writers for several ferns, by reason of the continuity of the radial walls. I was able to prove it for Dennstadtia by finding a number of mitoses ( $c f$. fig. 70, 6).

The stem very quickly attains its final diameter; hence its broadly rounded end. At a distance of $0.24 \mathrm{~mm}$. from the initial cell, in an average instance, all the cells have reached their ultimate width. Already at $0.18 \mathrm{~mm}$. in this case the epidermal cell-walls are thickening and becoming dark brown. At $0.345 \mathrm{~mm}$. the protophloem is mature and at $0.5 \mathrm{~mm}$. lignification is beginning in the xylem. In another case, however, the first thickenings of xylem occurred at $6 \mathrm{~mm}$. from the apex, and in another at $0.18 \mathrm{~mm}$. ( $c f$. fig. 70 ).

Excepting the epidermis, the first tissue to mature is the protophloem (fig. 107). For some time it forms a prominent ring of sma1l, angular, thick-walled fibers near each boundary of the vascular bundle. The walls stain deeply with hæmatoxylin. Seen on the side, the cells are very long and slender, and the walls are peculiarly and irregularly pitted. The xylem matures very irregularly. A cell here and another there become lignified, apparently without any order (fig. 110). The larger tracheids precede the smaller, the first ones being often near the exit of a root or leaf. No spiral cells are formed, and there is nothing that could be called protoxylem.

THE LEAF.

In the taxonomic literature of ferns the chief attention is directed to the leaf and its important appendages. Thus several references have already been made to the leaf of Dennstedtia (figs. 1, 2). In the following description we shall designate as petiole, the leaf-stalk, from the rhizome to the lowest pinna. All above this is blade. The continuation of the petiole in the blade we shall call rachis, and the thin expansion of the leaf lamina.

A11 of the leaves are alike in general appearance and in structure. There is no morphological distinction of sporophyll and trophophyll, although for various undetermined reasons some leaves are fertile and others sterile. Both kinds are produced throughout the season, though the greatest devel- 
opment occurs in May and June. Two to five leaves is the common annual growth from each branch of the stem. With considerable accuracy each leaf faces the chief source of light. When growing around an old stump or a bowlder, the leaves on every side turn their backs to it. On steep hillsides, also, the leaves face downhill. While not every leaf, by any means, stands thus, the general effect is very noticeable. The leaves stand nearly erect, but the blade is gently curved backward. A leaf which matures in June (first crop) turns yellow in August or September in eastern Pennsylvania and Maryland, by reason of old age (whatever that may be). In New England the first leaves persist throughout the season. The first sharp frost kills all of the foliage of Dennstedtia.

TABLE 6.-Data of the leaf.

\begin{tabular}{|c|c|c|c|c|c|c|c|c|}
\hline \multirow{2}{*}{ No. } & \multirow{2}{*}{$\begin{array}{c}\text { Total } \\
\text { length. }\end{array}$} & \multicolumn{2}{|c|}{ Length of- } & \multirow{2}{*}{$\begin{array}{l}\text { Maxi- } \\
\text { mum } \\
\text { width of } \\
\text { leaf. }\end{array}$} & \multirow{2}{*}{$\begin{array}{l}\text { Distance of } \\
\text { widest part } \\
\text { from base } \\
\text { of lamina. }\end{array}$} & \multirow{2}{*}{$\begin{array}{l}\text { Diameter } \\
\text { of petlole. }\end{array}$} & \multirow{2}{*}{$\begin{array}{l}\text { No. of } \\
\text { pairs of } \\
\text { pinnae. }\end{array}$} & \multirow{2}{*}{$\begin{array}{l}\text { Maxi- } \\
\text { mum No. } \\
\text { of pairs of } \\
\text { pinnules. }\end{array}$} \\
\hline & & Petiole. & Blade. & & & & & \\
\hline I & $\underset{\text { I I I }}{c m .}$ & $\begin{array}{l}c m . \\
23\end{array}$ & ${ }_{88}^{c m .}$ & $\begin{array}{l}\mathrm{cm} . \\
2 \mathrm{I}\end{array}$ & $\begin{array}{l}\mathrm{cm} . \\
24\end{array}$ & $\begin{array}{c}m m . \\
2.5\end{array}$ & ${ }_{4} 6$ & 24 \\
\hline 2 & 53 & I 3 & 40 & 16.3 & 15 & 2.2 & 37 & 22 \\
\hline 3 & $33 \cdot 5$ & 7 & 26.5 & 6.8 & 12 & I. 8 & 30 & 13 \\
\hline$\because 4$ & 41 & 10 & 31 & I I. 7 & 12.5 & I. 8 & 32 & 19 \\
\hline Av.of 10 & $60 \cdot 3^{8}$ & 14.2 & 46.18 & 16.49 & $15 \cdot 7$ & 2.02 & $37 \cdot 5$ & $21 \cdot 5$ \\
\hline
\end{tabular}

The petiole is slender, smooth, "chestnut-brown" (Clute, 1901), channeled on the upper (ventral) surface, about one-fourth of the total length of the leaf (not one-half, Clute, 1901). It is slightly stouter at base, e. $g$., $3 \mathrm{~mm}$. in diameter below and $2.5 \mathrm{~mm}$. above. The lower part is nearly always curved, often very much so, because of the obstructions the leaf meets in coming out of the soil. Above the earth it is straight and nearly erect.

The brown color of the petiole is due to pigment (phlobaphene ?) in the cell-walls of the epidermis and outer cortex. At the base, the cortex may be colored to a depth of nine cells. Passing upward along a newly matured leaf, the layer grows thinner, and just below the first pinnæ there is often no pigment at all. But the coloring advances upward with the age of the frond, until all of the rachis may become brown. The epidermal cells are very irregular in size. Near the rhizome they are polygonal and are about twice as long as broad. They become longer above. At $1 \mathrm{~cm}$. from the rhizome they are five times, and just below the blade seven to eleven times, longer than wide. In transverse section (fig. 69) they are. nearly isodiametric, but of very different depths. Each cell bulges out a little on the surface of the petiole. The cell-walls are thickly lignified, and bear numerous pits suggesting a continuity of protoplasm from cell to cell. There are many hairs, both glandular (fig. 249) and acicular (fig. $258, b$ ) on the young petiole, but they wither or are completely shed at 
maturity, leaving only the oval basal cell to show where they stood. The hairs are of the same character as those on the lamina. They will be described later.

Beneath the epidermis is a layer of brown, thick-walled sclerenchyma, as already mentioned ( $c f$. fig. 69). In the petiole proper these cells are long, and tapering at each end. Near the node they become shorter until they reach the dimensions of the cells of the sclerotic cortex of the stem, with which they are continuous. They may also unite here with a rod of similar tissue derived from the medulla of the stem and lying in the trough of the leaf-trace ( $c f$. p. 21). About the middle of each side of the petiole the sclerenchyma is interrupted by an extension of ordinary parenchyma out to the epidermis (figs. 69, 101). Stomata occur along this line to admit interchange of gases between the intercellular spaces of the parenchyma and the outside air. For a short distance near the surface of the ground the sclerenchyma is not so interrupted and stomata do not occur; but at about $1 \mathrm{~cm}$. from the rhizome the stomata and parenchyma begin again. The area occupied by them here is easily seen, because the walls of the sclerenchyma cells are of a deep-brown color, while those of the parenchyma are colorless. This area may end 0.5 to $2 \mathrm{~mm}$. above the rhizome, or may continue as a visible ridge on the posterior side of the leaf-base for $1 \mathrm{~mm}$. or more along the surface of the node. The guard-cells of these stomata stand above the level of the surrounding epidermis. Such lines of parenchyma are common in fern petioles, but by no means universal (Thomae, 1886).

From the epidermis inward, the cells become larger in diameter, shorter, less acute at the ends, and thinner walled. Two to ten cells in, according to height and age of section, we find soft parenchyma, with large watery cells bearing chlorophyll. These become smaller again next to the vascular bundle. They are in contact with the endodermis all around the bundle. This layer has many intercellular spaces in its middle portion.

The bundle itself is shaped like a trough, opening toward the upper surface of the leaf. In transverse section near the rhizome (figs. 82, 100, 101) it is U-shaped, or very nearly like the periphery of a semicircle. Its thickness is about the same all round. Higher up the petiole it is more V-shaped, flattened at the angle (fig. 68), and swollen at the tips of the short arms. The endodermis bears the typical Caspary's band. The contents of its cells take up stains with avidity, and probably include mucilage. A parenchymatous layer within the endodermis may be termed pericycle. Of two cells thickness in most places, it thins off to one cell around the tips of the arms of the bundle, and becomes three-celled on the outer side of each arm (fig. 68). At the latter place, also, the middle cells enlarge greatly to form a very peculiar open tissue. The thin band of xylem in the midst of the bundle follows the latter in general shape, but is more curved in its outlines. At the ends of the $U$ or $V$ it approaches very near to the peri- 
cycle and the tips are bent sharply inward or "hooked" (figs. 68, 69, 88-92). The "hook" is short at the base of the petiole, and much deeper above. Around the xylem there is a layer of conjunctive parenchyma. Between this and the pericycle lies the phloem. Its outermost layer all round is early developed as protophloem like that of the stem. It appears after the protoxylems, and develops first on the outer side of each arm of the bundle. Soon afterward it appears on the inner side of each arm. These four patches spread by addition of elements at each end until they meet and form a continuous sheath. The bulk of the phloem consists of sieve-tubes. No protoxylem elements (spiral cells) are found at the base of the petiole, but they appear shortly above, and are on the inner (upper, ventral) side of the xylem. The first to appear are two patches of slender spiral, annular, and spiro-annular elements, one in each corner of the flattened angle of the V-shaped xylem. Later another group (and finally two) appears on each arm beneath the hooked end of the xylem. Thus there are six protoxylems in all (fig. 68). They develop when the petiole is very young. But a very great enlargement of the tissues, both in length and breadth, takes place later, by which the protoxylem elements are quite torn to pieces. Neighboring parenchyma cells then push in to occupy the space, and the remaining lignin rings and spirals are often pushed out of their original places (figs. 116, 117). Thus originates the "cavity-parenchyma" of Russow (1871) (cf. Gwynne-Vaughan, 1901, p. 87). Its cel1s retain a fairly regular rectangular shape and are thin-walled.

The blade is from 30 to $90 \mathrm{~cm}$. long (see table 6) and 7 to $20 \mathrm{~cm}$. wide, lanceolate in outline, with the widest part from 5 to $40 \mathrm{~cm}$. above the base. It is pubescent, very soft in texture, and quickly wilts when plucked or frosted. Its delicate yellowish-green color has been mentioned above. It is thrice pinnate (fig. 2) with the margins of the ultimate segments deeply crenate (fig. 5). The veins are forked, without anastomoses. The vernation is of the typical circinate kind out to the divisions of the third degree. The crenations develop as the leaf unfolds.

The number of pinnæ varies from 30 to 50 pairs, and the maximum number of pinnules on a single pinna is 13 to 25 (see table 6). Though we speak of pairs of pinnæ, they are not exactly opposite. One of the lowest pair may be from 1 to $7 \mathrm{~mm}$. below the other. Those of the next pair, 2.5 to $8 \mathrm{~cm}$. above, are similarly separated from one another. Farther up, the pairs of pinnæ and the individuals of each pair are closer together, but the separation of the members of each pair is sufficient to make them appear almost alternate. Near the apex of the leaf the rachis is much like a midrib, and the divisions of the leaf diminish in size and degree. The uppermost "pinnæ" are mere crenations of the margin of a winged rachis. But morphologically they are pinnæ. The larger pinnæ, in a similar manner, have large, twice-divided pinnules; but these become smaller the farther they are from the rachis, until they, too, become mere crenations. 
The rachis of the leaf repeats in general the structure of the petiole. It is deeply channeled above, rounded beneath (fig. 69). The epidermis is very thick-walled, and is supported by a layer of sclerenchyma. This layer is thinner than it is in the petiole, especially on the back and sides of the rachis. In the ridge on either side of the groove it remains strong. About midway of each side of the rachis there is a line of spongy parenchyma with chloroplasts. Here the sclerotic sheath is interrupted and stomata are found in the epidermis (figs. 69, 114). The vascular bundle becomes narrower as we go up the leaf. From a very short, thick, V-shaped cross section it finally becomes oval. Now, the xylem is a band with hooked ends. The protoxylems are only two, lying inside the hooks. Cavity parenchyma still accompanies them (fig. 114).

The oval form of bundle just described is also found in the base of the rib of the larger pinnæ. These ribs, indeed, fully repeat the outlines and structure of the upper part of the rachis. The vascular bundle of the rib springs from that of the rachis in the following manner ( $c f$. figs. 88-92). The hook of the xylem at one end of the U-shaped petiolar bundle gradually becomes twice as deep as before, and a bridge of xylem is formed across the middle of the hook. A constriction now cuts through the bridge, separating from the bend of the hook a small ring of xylem filled with phloem. The constriction later affects the endodermis, and the new bundle is completely separated. As it bends out into the pinna, the xylem ring grows thicker below and thins out to nothing above, until only a single transverse band of tracheids remains in the middle of the bundle. A strand of protoxylem lies on the upper side of this band, and is continuous with that of the rachis.

The veins and veinlets of the leaf are collateral in structure, cylindrical, with distinct endodermis. Their xylem consists wholly of spiral tracheids. The ribs of the uppermost pinnæ are also collateral throughout, with xylem above and phloem beneath.

The structure of the lamina is very simple. An unbroken epidermis of wavy-margined cells (fig. 112) covers the upper surface. If any cuticle is present, it is extremely thin. Over the veins the cells are elongated and approximately rectangular. The lower epidermis (fig. 111) bears many large oval stomata about $0.023 \mathrm{~mm}$. by $0.038 \mathrm{~mm}$. There are about eight of them per square millimeter. They are set exactly level with the epidermal cells. Copeland speaks of them as follows (1902, pp. 349, 350):

In the Polypodiaceæ I have examined, there is an approach to what Haberlandt calls the type [of stoma] of swimming plants, in that the ridge of entrance is well developed, while the ridge of exit is inconspicuous or not present. In Dennstadtia punctilobula Bernh. (figs. 40, $4 \mathrm{I}$ ) [cf. our fig. 104] this thickening of the ridge of entrance has gone far enough to give the stoma a rigid appearance, but it is really motile. Opening seems to be effected by a movement of the ridge of entrance outward as well as backward, such as must occur in lesser degree in the case of Angiopteris. The guardcells of Dennstadtia are thin-walled and shallow at the ends. 
In the following table the depth is measured from the ridge of entrance down to the deepest dorsal focus. The stoma was closed by displacing water with alcohol.

\begin{tabular}{|c|c|c|}
\hline & Open. & Closed. \\
\hline Width of stoma..... & ${ }_{30}^{\mu}$ & ${ }_{28,5}$ \\
\hline Width of guard-cells............ & 13.5 to 14 & 14 to 14.5 \\
\hline Width of pore.................... & 2.5 & o \\
\hline 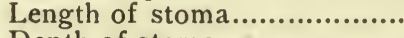 & 44 & 45 \\
\hline Depth of stoma..................... & I7 & 14 \\
\hline
\end{tabular}

[p. 350] The first effect of the alcohol is to widen the pore, which then gradually closes, the sides becoming apparently straight before they meet. The increase in depth at the ends, which is partly responsible for opening the pore of this stoma, works to better advantage than in the stoma of Osmunda.

The cells of the lower epidermis (fig. 111) are smaller and more wavy than those of the upper surface. All of the epidermal cells contain chloroplasts, but they are especially abundant in the guard-cells. The thickness of the lamina runs from $0.06 \mathrm{~mm}$. at the veinlets to $0.09 \mathrm{~mm}$. where the mesophyll is well developed. The air-spaces are especially large in the lower half of the spongy parenchyma. A continuous layer of irregular cells lines the upper epidermis, but there is nothing that could be called palisade tissue (fig. 113).

Scattered plentifully all over the leaf are hairs of two kinds-acicular (fig. 258, b) and glandular (figs. 105, 113, 249). The first are simple, acute, septate, often 1 to $2 \mathrm{~mm}$. long. The latter are simple, septate, with a spherical terminal cell, and from $0.08 \mathrm{~mm}$. to $1 \mathrm{~mm}$. long. The terminal cell (or sometimes two cells) is surrounded by a globule of secretion. In this doubtless resides the ethereal oil which gives the characteristic scent to the plant. Waters (1903, p. 290) states that the odor is stronger in plants grown in dry, sunny places than in those grown in shade, and that it is changed and intensified in drying the leaves. By "distilling with steam" a "considerable quantity of the partly dried ferns, . . . two or three drops of oil were obtained . . . It had a rather disagreeable odor, but when a drop or two of a solution of the oil in a large amount of ether was put on paper and the ether allowed to evaporate, a very pleasant reminder of 'new-mown hay' resulted', (Waters, 1903). One bottle of fronds preserved in 50 per cent alcohol has retained the odor strongly, and it adheres very persistently to hands or clothing after the alcohol has evaporated.

The leaf-shoot, several times referred to above, attracted my attention in the fall of 1901. It is the stem which comes off from the base of the petiole (fig. 4). About 20 per cent of the leaves bear such shoots, the remaining 80 per cent showing no trace of them whatever. The shoot arises on the side of the petiole at a very early stage of development, but I was not able to find its relation to the sectioning of the segments of the leaf. I believe 
the shoots arise often after the section lines are obliterated. They lie above (ventral to) the stomatic line of the petiole. At maturity the shoot is from 3 to $8 \mathrm{~mm}$. (average of $10=5.4 \mathrm{~mm}$.) from the rhizome. It is in all respects a stem. Its tubular stele is attached nearly at right angles to one margin of the trough-like vascular bundle of the petiole (fig. 82). The stele usually appears truncate at its point of origin, but it may be slit on its upper side, giving a trough-like shape (figs. 93-96). I have never found any commissural strand connecting the shoot directly with the stem. as noted by Gwynne-Vaughan (1903) in other solenostelic ferns. The inner parenchyma of the petiole is continuous with the medulla of the shoot. Occasionally two shoots arise on opposite sides of a single petiole; they are then either opposite or as much as $2 \mathrm{~mm}$. apart. The shoot may remain dormant as a mere papilla for two or three years, or its growth may be extremely slow, or it may from the first nearly equal in size the leaf from which it springs, or the leaf may fail to develop (owing to injury by fungi, etc.) and the shoots alone continue. Ultimately the leaf-shoots produce normal rhizomes, as shown by one which I measured in March, 1905. It was $12 \mathrm{~cm}$. long, $1.5 \mathrm{~mm}$. in diameter at its origin and $2.6 \mathrm{~mm}$. at $4 \mathrm{~cm}$. from its origin. During previous seasons it had borne three leaves, and two more were ready to develop in 1905 . The apex had just forked.

The descriptions of leaf-development given by Sadebeck (1873, 1874, 1878, 1898), Kny (1875), and Campbell (1887, 1895, 1905) contain some points which I can not interpret, and the leaf of Dennstcedtia differs in its development from that of the Hymenophyllaceæ as given clearly by Prant1 $(1875, a, b)$. The leaf takes its origin from a deep four-sided prismatic cell in the apex of the stem (figs. 103, 109, 118, 121, 128). The cell is sometimes recognizable by its large size in the fourth segment from the stem initial (fig. 109). It seems reasonably certain that not every stem segment gives rise to a leaf, nor even two out of every three segments. The location of the leaf-initial in the segment also varies much, according to the size and rapidity of growth of the stem. It is usually near one margin of the segment (figs. 103, 109), and may lie very near the stem-initial until many divisions have occurred in it (figs. 128, 129). The leaf-initial in its earliest stage extends into the stem as far as the future boundary of medulla and plerome. Its divisions are different from those of the neighboring cells - a fact which is related to the formation of the leaf-gap. No definite order could be discovered in the early divisions of the leaf-initial. It maintains its four-sided shape for some time (figs. 118, 121), then is cut obliquely (figs. 121, 122-127) and becomes tetrahedral. After forming a few segments on three sides, the initial ceases to form segments on one of the three sides and it becomes "two-sided." Meanwhile, all of the cells derived from the primitive leaf-initial are elongating and forming a papilla on the stem apex, at the tip of which the definite apical cell of the leaf is situated (fig. 70). This cell is wedge-shaped (figs. 123, 130) and very broad across 
its exposed face. As segments are cut off from it alternately on the two sides, it itself becomes narrower, and finally very slender (figs. 131, 135). Each segment divides first on the ventral side by a radial anticline which cuts off a narrow cell running from the periphery to the center of the leaf-rudiment (figs. 132-134, 140). A similar wall near the dorsal margin of the segment meets the first nearly at right angles, close to the center of the leaf-rudiment. The two narrow cells may be called sections (Johnson, 1898) and the walls section-walls. The remaining triangular portion of the segment is a primary marginal cell. The segment enlarges and a wall parallel to the segment walls (transverse anticline) divides the primary marginal cell into two equal secondary marginal cells (figs. 132-134). In each of these two new section-walls occur, one ventral, one dorsal. Thus there is a regular alternation of section-walls with a halving of the marginal cells. At least six or seven section-walls are formed in the region which is to become petiole or rachis. The ultimate marginal cell is then cut across by a periclinal wa11 (figs. 142, 143). Its specific activity is ended and its outer portion breaks up into epidermal cells. The relation of the sections to the inner tissues of the petiole and rachis (vascular tissues, etc.) differs in different places, and was not worked out in detail.

No sooner has the leaf-rudiment become a conical projection on the stem than it begins to grow more actively on the dorsal side-to bend over toward the stem-initial-to become circinate. The initial cell of the leaf lies with one point (in cross section) towards the stem initial and the ventral (upper) surface of the leaf, the other point in the dorsal (lower) surface of the leaf.

The circinate vernation comes about through the rapid growth in thickness of the dorsal sections of the segments. The cells divide about twice as rapidly as in the ventral sections, and are larger (figs. 136, 139). A little later, divisions occur on the ventral side to about the number of those on the dorsal, but the curved position is maintained by greater elongation of the dorsal cells. Finally, when the leaf unfolds, the ventral cells elongate to equal those of the dorsal surface.

The activity of the initial cell of the leaf is, as in most ferns, limited. After the rudiments of five to eight pairs of pinnæ are visible and about three pairs of segments are cut off in advance of any visible differentiation into pinnæ, the initial ceases to exist as such. Probably it simply begins to divide into sections as a segment would do. Fig. 138 shows a leaf-tip at this stage, where the initial has divided twice in succession on the same side. There is no evidence at all for a "transverse" division of the initial. After the initial is lost the leaf-apex is occupied by a group of marginal cells (figs. 137, 144) which grow and section and divide into halves for a long time. Since it is probable that each segment of the initial (while it lasts) develops a single pinna in the region of the lamina, we may say that the lowest eight to eleven pairs spring from as many 
segments. The remaining 22 to 40 pairs of pinnæe come out after the single initial is lost. In either case their actual history is the same.

The apical growth of the leaf, with or without a single initial, gives rise directly to a slightly flattened and circinately curved rod of embryonic cells (figs. 140, 141, 144). Each margin is occupied by a row of marginal cells (fig. 137). Where a pinna is to develop, about six consecutive marginal cells elongate to form a papilla. By sectioning and halving they rapidly increase in number of cells and mass of tissue. The apex of the papilla and its manner of growth are exactly like those of the tip of the leaf after the loss of the initial cell (figs. 145-147). On the sides of this protuberance similar outgrowths form the pinnules, and on the pinnules, in a similar manner, the lobes of the pinnule arise, and on these again, in like manner, the ultimate crenations of the leaf-margin (figs. 5, 148, 149). From the inner ends of the oldest sections in each part of the leaf the vascular tissues are derived (fig. 149). In every case also there are inactive marginal cells between those groups which grow out to form pinnæ, pinnules, lobes, and teeth. These sluggish cells ultimately give rise to the tissues along the rachis between the pinna, or along the ribs between the pinnules, or in the notches of the pinnules (fig. 148). In the lamina proper, away from any vein, the sections of the marginal cell are broad and shallow, extending only half the thickness of the leaf (fig. 150). Each of the sections is halved parallel to the surface of the leaf. The outer half is an epidermal cell; the inner half remains single or divides again in the same plane and forms parenchyma (fig. 150). The ultimate marginal cells constitute the margin of the mature leaf. Stomata are formed while the epidermal cells are still polygonal in outline, and while the leaf is unfolding. A curved wall cuts out the stoma mother-cell on one side of a young epidermal cell (figs. 152, 153). The mother-cell becomes oval and is divided longitudinally into the two guard-cells.

With 20 to 25 pairs of rudimentary pinnæ, no stomata, no air-spaces in the parenchyma, and no signs of fructification, the leaves emerge from the soil. It would be, therefore, quite a mistake to suppose that in Dennstcedtia punctilobula the unfolding of the leaves "consists merely in an expansion of the leaf with comparatively little cell division' (Campbe11, 1895, p. $325 ; 1905$, p. 333 ), in spite of the rapidity with which the unfolding takes place. One-third to one-half of the blade of the leaf must be made outright during this time. In eastern Pennsylvania and Maryland the leaves appear above ground in the latter half of April (Cockeysville, Maryland, April 21; Oxford Valley, Pennsylvania., April 29, 1905). By June 4 (Loch Raven, Maryland, 1905) spores are nearly mature. At first the petioles, green in all the aerial part and clothed with white hairs, elongate and unroll. Then the leaf spreads out from below upward. A comparison of figs. 2 and 5 of the mature leaf and fig. 152 of a pinnule $3 \mathrm{~mm}$. long from an unrolling leaf will give an idea of the change that goes on. In fig. 152 the stomata 
are just developing. The pinna from which this was taken was $1.5 \mathrm{~cm}$. long, and unrolling.

While it is unfolding (May 4, 1906, Baltimore, Maryland), the fertile leaf acquires its sori. In origin the sori are strictly marginal. At the point where a sorus is to develop, a marginal cell of the lamina, at the tip of a rudimentary veinlet, after giving rise to a mass of vein and lamina cells, grows out into a short, rounded papilla (figs. 151, 158; cf. also fig. 63D in Sadebeck, 1898). This papilla is the rudiment of the first and central sporangium. Neighboring cells elongate to form a mound, the placenta. New sporangia at once begin to develop around the first one. Meanwhile, about four or five cells removed from the central marginal ce11, the leaf-tissues begin to rise up in a ring (indusium) around the placenta (fig. 158). The ventral (upper) part of this ring soon becomes much thicker than the opposite side-as thick, indeed, as the lamina itself. Vascular tissues, also, are formed for a short distance into this lobe (fig. 155).

As growth proceeds, the sorus reaches its ultimate position on the under side of the leaf. One is found on the lower outer venule of each lobe of each pinnule (fig. 5). At maturity the indusium is circular and cupshaped. One side of it is continuous with the margin of the leaf (fig. 155); elsewhere it rises abruptly from the surface. In its lower parts it consists of inner and outer epidermis, with a few parenchyma cells and airspaces between. Here stomata occur both within (fig. 120) and without (fig. 119). The epidermal cells are wavy-margined (fig. 115). The indusium tapers above to two cells, then to one cell in thickness. On its sides and margin it bears hairs, both glandular and acicular. The margin is irregular. In the bottom of the indusium cup and on the side nearest to the base of the pinnule is a low, rounded placenta. It is covered with epidermis, beneath which is a layer of parenchyma, and then a group of short scalariform tracheids (fig. 155). These last constitute morphologically the end of the neighboring venule, which appears to terminate under the sorus just beyond the placenta. The apparent ending is really a branch in the indusium. From the placenta arise a few paraphyses (figs. 169, 173) and number of sporangia. The paraphyses are obtuse hairs, composed of about three cylindrical cells each.

The sporangia arise in centrifugal succession from superficial cells of the placenta. The mother-cell bulges out considerably and is cut by an oblique wall from the middle of its base to one side of its summit (fig. 159). A second oblique wall strikes across from one side of the summit to the first wall (fig. 160). A third wall, striking both of the preceding, leaves an upper cell with a spherical outer surface and a triangular pyramidal base. Three more divisions follow in the upper cell, parallel to the first three (fig. 157). Then a transverse wall cuts across the top, leaving a central tetrahedral ce11 (the primitive archesporium) surrounded by four wall-cells (figs. 154, 156). The three lowest and earliest-formed cells 
divide only transversely, and give rise to the three rows of cells of the stalk (fig. 176). The four wall-cells form the walls of the sporangium.

The archesporial cell at once cuts off four tapetal cells (figs. 161, 162), one on each of its facés, beginning on the sides. Each tapetal cell divides into four by anticlinal walls. The archesporial cell then divides nearly vertically into two, and the tapetum divides periclinally into two layers (fig. 163). The exact relation in time of the divisions of archesporium and tapetum is not constant (figs. 164, 166). From this time onward the archesporial cells divide exactly synchronously, though in different planes, first into four (figs. 165, 166), then into eight, and finally into sixteen. As soon as the sixteen spore mother-cells are formed the tapetum begins to degenerate (figs. 167, 170). Its walls dissolve, and the cytoplasm forms a vacuolated mass, but the nuclei persist until the spores are acquiring their definite walls (fig. 168). The spore mother-cells, at first in a solid mass (fig. 167), enlarge rapidly and separate from one another. Their nuclei especially increase to a relatively great size (fig. 170). The chromatin now lies in innumerable fine granules. Then a long, fine, and tangled chromatin thread is organized, and synapsis ensues. This must be a lengthy stage, as it is frequently and easily found. Emerging from synapsis, a heterotypic division occurs. The two resulting nuclei at once divide again, and spindle fibers are formed between all four of the daughter nuclei. Across the fibers cell-walls are laid down. The spores remain together in fours until their walls are thickened. They separate before the final sculpturings are formed on the outside. Thus the spores always show a tetrahedral angle. The sculpturings are irregular lines and lumps of brown substance (figs. 174, 175). A11 stages in the formation of sporangia and spores may be found in a single collection of material from newly unfolded fronds (e.g., Loch Raven, Maryland, at base of a steep hill facing north, Junc 4, 1905). Meanwhile the wall of the sporangium has also reached its mature size and structure. The sides consist of very thin, broad cells, about eleven on each side. The right and left sides are nearly identical (figs. 171, 172). The annulus runs from the stalk up one edge and over the top of the sporangium and about one-quarter of the way down the other edge. Its cells, 18 or 19 in number, are cubical and are heavily lignified on all except the outer walls. The mouth of the sporangium, or point of rupture, lies between two long, narrow, slightly thickened cells (sometimes two such cells on one or the other lip) about midway between the end of the annulus and the stalk. Similar long, narrow cells, three to five in number, but with thin walls, fill up the space above and below the mouth. At maturity the whole sporangium and contents dry out, and the spores are hurled away as described for another fern by Atkinson (1894). The annulus tends to straighten, and it does so, slowly opening the mouth of the sporangium and tearing the walls nearly straight across their whole width. It bends far around backward until the head 
of the sporangium nearly touches the stalk. Meanwhile some spores have fallen out, others remain in each half of the sporangium. Then suddenly the annulus springs back to its former place, throwing its load of spores several centimeters. Straightway it begins slowly to bend back again, and repeats the operation. The springing of the thin walls during both the extension and the recoil of the annulus throws out several spores.

\section{GAMETOPHYTE.}

Spores sown on moist micaceous earth about October 3, 1905, had mostly germinated and formed protonemata by the 25th.* About October 1, 1905, also, fresh male and female prothallia and young plants in various stages of development were found in a ravine near Baltimore, Maryland. In germination the spore-coat bursts at the tetrahedral angle. The intine bulges out, and a cell with many chloroplasts appears (fig. 177). It immediately sends out a rhizoid which is separated by a wall from the cell. Some of my cultures became temporarily dry at this stage, and the first rhizoid died. Another was soon sent out from a point farther up on the same cell (figs. 191, 193). The protonemata assumed a great variety of shapes (figs. 178-199). There were from one to six cells, in linear series. The basal cell was sometimes very long and slender (figs. 184, 196), or rarely broader than long (fig. 182). The basal cell was usually the longest of all, but not always (fig. 197). The growth of the protonema is by transverse divisions in the apical cell. Rarely an intercalary division occurs in a longitudinal plane.

Sooner or later the terminal cell divides longitudinally in half (fig. 189). One half enlarges more than the other, causing the partition to become oblique. Then an oblique wall cuts the larger cell, striking the next earlier wall nearly at right angles (figs. 185, 196). The result is a twosided apical cell, which continues to divide parallel to its two sides for a long time (figs. 187, 188, 190). The young gametophyte now becomes broader at the apex (figs. 194, 195). Soon the cells on either side of the initial outgrow those just behind it, and the prothallus assumes its cordate shape (figs. 199, 200). The initial is then changed by a transverse wall across its posterior end (fig. 203). After this it divides into two longitudinally, and we can henceforth recognize only a group of marginal initials (fig. 200). Each of these cells divides on three sides, viz, two lateral and one posterior (figs. 202, 204-207, 214).

* My cultures were sown in 3 -inch to 6-inch flower-pots and pans on micaceous soil dug from deep down in a newly exposed bank of earth. Ripe leaves were laid on the pots, covered loosely with papers, and allowed to dry and shed their spores. Or, the débris of dried fertile leaves was sown. The pots and pans were never sprinkled, but were kept standing in $\mathrm{t}$ to $2 \mathrm{~cm}$. of water, covered with glass plates, before a west window of the Johns Hopkins Biological Laboratory. 
Meanwhile many rhizoids are reaching from the under surface of the prothallus into the earth (fig. 231). Hitherto all of the divisions mentioned have been vertical, and there is but one layer of cells. When, as in female plants, a "cushion" is formed in the middle of the prothallus, divisions parallel to the surface occur in the posterior segments of the initials (figs. 202, 205-207, 214). The upper half of the segment may divide once or twice in this plane, giving rise to two or three layers of cells. The lower half is responsible for most of the bulk of the cushion and for all of the organs which appear thereon (figs. 206, 207). In crowded cultures wart-like outgrowths occur on the upper surface of the prothallus (fig. 201). They can only be considered as abnormalities.

The prothallia reach sexual maturity at five weeks and later from sowing of spores. They are practically always diœecious. Only three hermaphrodites have I seen. On one of these male and female organs seemed to be mature at the same time. The males mature first, and they may continue to grow and bear great numbers of antheridia for five months or more. Antheridia may appear on very small plants. I found one in a glen near Baltimore, Maryland, in which there were four prothallial cells and three antheridia (fig. 198). All sizes and shapes occur from this up to those which are $5 \mathrm{~mm}$. across, with many lobes, and the margins crisped like a "curly" lettuce-leaf. Whether those which bear sexual organs at a very early age ever develop to large size I do not know. Probably they do not.

The male prothallus is always but one cell thick; it has no cushion. The antheridia arise at any point on the shaded side-central or marginal (figs. 227, 228). In large "curly" specimens the relation to light is clearly shown. A section may-show an S-shaped portion of prothallus. Supposing the light to come from the upper edge of the page, the antheridia will be found on the lower side of each transverse bar of the S. Two of these will be the morphologically lower surface and one the upper. At transition points two antheridia may be seen on opposite sides of the same cell!

The antheridium arises from the prothallial cell as a papilla, which is soon cut off by a basal wall (fig. 225). It differs in appearance from a young rhizoid in having many chloroplasts, though the rhizoid rudiment may have two or three. In preserved material this difference is not evident. The papilla enlarges and is cut in two by another wall parallel to the first (fig. 226). The first cell is the stalk-cell, and undergoes no further division; the other is the antheridial mother-cell. The next two walls are those commonly described for fern antheridia, viz, first a domeshaped wall parallel to the outer wall of the mother-cell (figs. 228, 232); second, a circular wall at the summit of the outer cell to form the lid. The body of the antheridium now consists of a cylindrical wall-cell, a circular cap-cell, and a large, dense central cell. The central cell is devoid of chlorophyll. It divides at first vertically (fig. 227), then in three 
planes at right angles to one another, and at last irregularly (fig. 230), to produce 32 sperm mother-cells. These separate and round off, and in each one a spiral spermatozoid develops. As the central mass enlarges it pushes itself down into the center of the stalk-cell until it reaches the original basal wall (figs. 230, 237). Thus the stalk-cell becomes ringshaped, though at first it was a disk (figs. 226, 229). At maturity the contents of the antheridium swell up by absorption of water, the cap-cell is ruptured irregularly, and the sperm mother-cells escape. After 45 to 50 seconds the mother-cell wall bursts and the spermatozoid swims rapidly away with a steady rotary motion, bearing a granular vesicle at the posterior end. From cultures of male prothallia kept free from surface-water it is easy to get numbers of spermatozoids by mounting the prothallia in water. Mr. W. D. Hoyt found them to be distinctly attracted by a malicacid solution of suitable strength. The body of the sperm makes about two and a half coils. The anterior end is more slender and more closely coiled.

\section{TABLE 7.-Development of antheridium.}

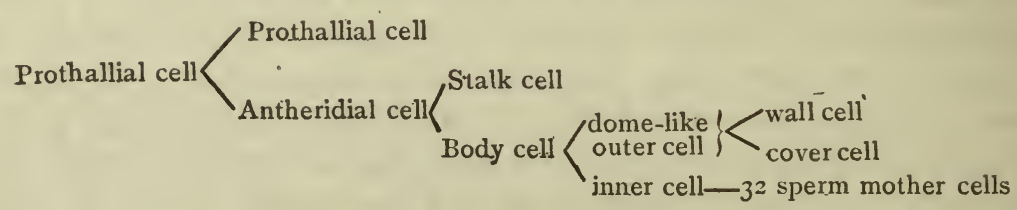

Female prothallia are always cordate in shape and bear their archegonia on the under side of a central thickening or cushion. They begin to form sexual organs when still narrower than long, five or six weeks from sowing of spores. If not fecundated they continue to grow larger and broader, and produce many archegonia in succession over all the central lower surface. The upper surface is at first flat, but in old females the margins may become reflexed dorsally, and the plant forms a broad, erect funnel, open on one side. The largest in my cultures are 5 to $7 \mathrm{~mm}$. tall and 6 to $9 \mathrm{~mm}$. across. I found one out of doors $7 \mathrm{~mm}$. wide and $4 \mathrm{~mm}$. long.

The archegonium develops from a cubical superficial cell of the prothallus, near to the initial cells. This cell may be a semi-segment, involving half the thickness of the prothallus (fig. 202), or it may be simply the outer part of a semi-segment (figs. 206, 214), according to its point of origin on the prothallus and the size and thickness of the latter. In any case the definitive archegonial mother-cell first cuts off a thin superficial cell, the neck rudiment (fig. 202). Then on the opposite side a similar basal cell is separated, leaving a large central cell (figs. 206, 207). The basal cell divides crosswise into four and forms the innermost part of the wall of the archegonium (fig. 208). The neck rudiment similarly divides crosswise into four (fig. 207). Its first cleavage wall is parallel to the longitudinal axis of the prothallus. Now the central cell enlarges and pushes out the four neck-rudiments. As the latter project more and more 
from the surface of the cushion they divide each into a row of cells (figs. 208-213). The neck, therefore, consists of four rows of cells (figs. 213, 220-222), two anterior and two posterior. The divisions always occur in the uppermost or next to uppermost members (fig. 210). At maturity the neck bends over strongly away from the growing point of the prothallus (figs. 207, 211, 219). In relation to this we find in each of the two rows of cells of the neck on the convex side two cells more than on the concave side ( 4 and 6 , or 5 and 7 ).

Meanwhile the central cell has cut off a "neck canal-cell" (figs. 209, 210), which pushes up in the axis of the neck. It acquires two nuclei (fig. 215), rarely three (fig 218). Another division in the central cell cuts off the "ventral canal-cell," lying at the base of the neck (figs. 216, 217, 218). The large remainder is the egg-cell. As the archegonium matures the neck enlarges and becomes swollen near the end (fig. 219). The canal-cells degenerate into an amorphous mass, the central parts of which stain deeply with hæmatoxylin. At this time also a distinct venter wall is formed around the egg by divisions in all the prothallial cells surrounding it (figs. $219,223,224$ ). To recapitulate, the archegonium as a whole is made up from two sources-the neck, canal-cells, egg, and four basal cells of the venter are all derived from the original cubical archegonium mother-cell; the side walls of the venter are derived from all the neighboring prothallial cells.

TABLE 8.-Development of archegonium.

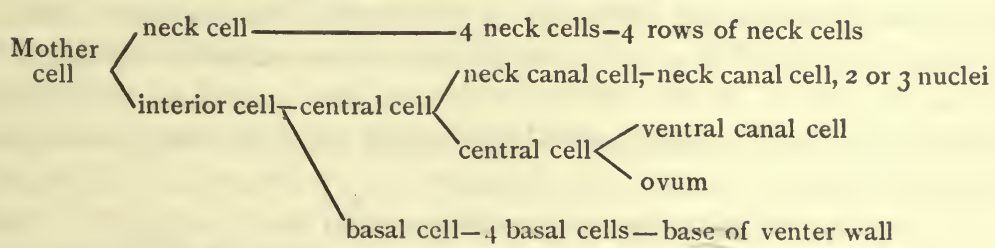

Surrounding cells of prothallus form side walls of venter.

When the archegonium is wholly mature, the uppermost four or eight neck-cells break apart, leaving a wide-open mouth (figs. 220, 224). Through this a transparent mucilaginous substance exudes, and may stream out for a distance several times the length of the archegonium (fig. 224). In this substance spermatozoids gather in great numbers. As a sperm enters the mucilage its movements become slower, and it changes from a short, stout helix to a long, slender one with more turns. The vesicle attached to its posterior end is twisted off by the resistance of the mucilage and floats away. The sperms swarm into the neck and make their way down towards the egg, which becomes pointed as though reaching out to receive them (fig. 223). The lower part of the neck is so constricted (fig. 222) that the sperms have to become nearly straight to get through, but many succeed in doing so. 
The remains of unsuccessful sperms are left after fecundation as a deeplystaining cap over the top of the egg-cell. The fertilized egg rounds off and comes to rest, with a large central nucleus and nucleolus (fig. 224).

About half of the mature prothalli, with apparently perfect archegonia, will actually be fertilized when mounted on a slide with mature males. In such cases not only is the receptive archegonium filled with sperms, but many older archegonia, up to a dozen on a single plant, including such as are brown with age, are quite as eagerly crowded into by numbers of sperms. Only once, however, have I known two embryos to appear on one prothallus. Young archegonia continue to develop on the fertile prothallus for a time. But after the embryo is fully established (i.e., octant stage), sexual organs cease to develop. Fertilized eggs were found about 7 days after my cultures had been flooded with water. In 16 days many embryos were visible with a hand-lens.

\section{THE YOUNG SPOROPHYTE.}

The first cleavage-plane (basal wall) in the fertilized egg includes the axis of the archegonium, and lies transversely to the axis of growth of the prothallus. It divides the egg into anterior and posterior halves (see below). The second (quadrant) wall passes horizontally and at right angles to the axis of the archegonium. In each quadrant, then, a vertical wall is formed at right angles to the two preceding, dividing the embryo into octants. These octant walls do not correspond in the different quadrants, but the octants are from the first unequal in size (figs. 233, 234). Supposing the prothallus to lie before the observer with cushion downward and the notch on the farther side, we may speak of right and left, anterior and posterior, upper and lower portions. The fate of the octants may be stated thus:

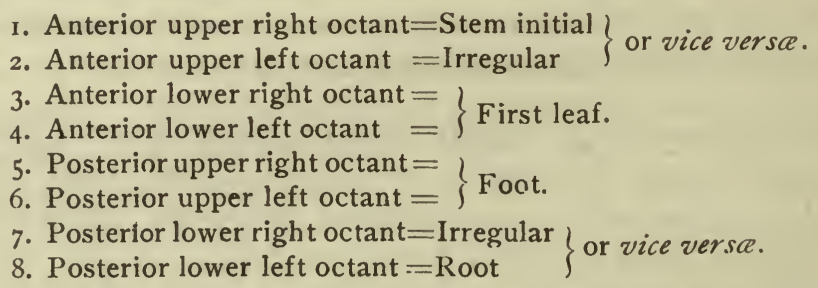

It must not be supposed, however, that this arrangement is invariable. On a prothallus with two embryos one has the root-intitial in octant 8 , the other in 7 . Octants $2,3,5,7$ are smaller than $1,4,6,8$. The first division in $2,4,6,8$ is parallel to the basal wall and near to it. In 8 the succeeding divisions are parallel to the other primary walls, and then to the curved outer wall. The resulting tetrahedral central cell is the root initial. It continues to divide in the way which is characteristic for roots (q.v.) (figs. 235, 236). 
The two posterior upper octants $(5,6)$ divide irregularly into a mass of polyhedral cells, the foot. Those in contact with the base of the archegonium become closely applied to the wall, and the boundary between prothallial and embryonic tissues is often difficult to determine. Neighboring cells of the two anterior upper octants are also involved in the formation of the fully matured foot (figs. 235, 236, 246).

Octants 2 and 7 divide irregularly and serve only to fill up their respective corners of the embryo plant. Octant 1, after cleavages mostly paralle1 to the basal and quadrant walls, ultimately gives rise to the stem-initial, lying close to the octant wall, $i . e$, near the median line.

The lower anterior octants ( 3 and 4 ) elongate together in a horizontal direction (fig. 255). They unite at their anterior ends to form a group of marginal initials for the first leaf (cotyledon). This leaf, therefore, never possesses a single apical cell.

As the leaf grows out, the whole anterior (epibasal) half of the embryo elongates, carrying forward both stem-initial and leaf. The plantlet lies horizontally. It consists of a short cylinder with root-initial at one end, leaf-initials at the other end, a dorsal papilla near the middle, in which is the stem-initial, and back of this a large dorsal protuberance, the foot, buried in the prothallus (fig. 246). The whole is surrounded by the greatly enlarged archegonial wall, the calyptra. The latter has become two or three cells thick all round (figs. 246, 255). Soon the leaf bursts through the calyptra and bends upward through the notch of the prothallus, and the primary root extends downward. The new plant is now independent, but the prothallus does not disappear until two or three leaves are formed (fig. 267).

The young stem grows almost horizontally for 1 or $2 \mathrm{~mm}$., increasing in diameter and complexity of structure until about five leaves have been formed. The stem then forks. The plant now differs only in size and sterility from the adult. The primary root grows about $5 \mathrm{~cm}$. long, is slender, and has the structure of an adult rootlet $(q . v$.$) . It is not$ branched, but has copious root-hairs. Adventitious roots arise in rapid succession, being sometimes as many, sometimes twice as many, as the leaves (fig. 256). They are like adult roots, only smaller. I have one specimen whose root-cells are densely filled with fungous hyphæ, after the manner of the adult mycorhiza. The prothallus is also infected, but there is no connection (internally at least) between the fungous masses in sporophyte and gametophyte.

The sporeling stem is short and cylindrical (figure 269). It is clothed with an irregular epidermis. The cortex, parenchymatous below, merges gradually into that of the adult region. The stele of the primary root is continuous with that of the stem. There is no line of demarcation on the ventral side, but dorsally a prominent angle of vascular tissue projects toward the foot (figs. 246, 247). Between this point and the insertion of 
the first leaf the stem is protostelic. It contains a solid core of scalariform tracheids (xylem), surrounded in succession by conjunctive parenchyma, phloem, pericycle, and endodermis (fig. 238). At the exit of the first leaf-trace there is a depression containing parenchyma on that side of the xylem (fig. 239). Farther up the xylem extends around so as to inclose this parenchyma. In the parenchyma, even before the exit of the second leaf-trace, phloem and conjunctive parenchyma may be recognized (fig. 240). The second leaf makes a similar gap in the xylem. Between the second and third leaf-gaps there appears in the midst of the central phloem a group of large cells identical in appearance with the outer pericycle (fig. $241, i p)$. At the exit of the third leaf-trace the outer pericycle becomes continuous with the central tissue just mentioned, through a gap in the xylem and phloem (fig. 256). The gap closes again without any dipping in of the endodermis. Below the fourth leaf there appears a thickened band (Caspary's band) on the cross wall between two parenchyma cells at the center of the stele (fig. 242). In the next section (10 $\mu$ higher) there is a line of five cells whose intermediate walls bear the thickened band characteristic of endodermis (fig. 243). Two sections higher $(20 \mu)$ there is a ring of endodermis at the center of the stele, inclosing one sclerenchyma cell (fig. 244). The ring enlarges rapidly and parenchyma cells appear beside the sclerenchyma (fig. 245). The solenostelic structure is established. The fourth leaf-gap is like the third, with only a very slight dipping inward of the outer endodermis (fig. 257). Only at the fifth or sixth gap, i. e., above the fork of the stem, is there a continuity established between inner and outer endodermis and between medulla and cortex, as in the adult plant. The above description is of an average case. The exact position of each stage differs according to the size of the individual sporeling. The whole course of development is remarkably identical with that described by Boodle (1901) for the early stages of Aneimia phyllitidis. Dennstadtia stops at the solenostelic stage, while Aneimia goes on to become dictyostelic.

To the practiced eye the first leaf of a young fern is often sufficient to distinguish the species. In any case the third, fourth, or fifth leaf will bear undoubted specific characteristics. The first leaf of Dennstadtia punctilobula is usually two-parted, with each part bifid at the apex (figs. $259,267)$. In more slender examples the two lobes are narrow, elliptic, and entire. I have seen two cases where the leaf bore but one elliptic entire bit of lamina. The average leaf measures $0.32 \mathrm{~cm}$. to $0.38 \mathrm{~cm}$. across. Its venation is simply forked. In the bud it is folded over at the tip in involute manner, but could hardly be called circinate. The same is true of the rudiment of the second leaf. The second leaf is also broad and lobed. It has three or four main lobes, each bifid or emarginate at - apex. It is larger than the first, being 0.46 to $0.81 \mathrm{~cm}$. in width and 0.4 $\mathrm{cm}$. or less in length (figures 260,261 ). The third leaf is pinnately 
divided, with a comparatively broad, winged rachis. There are one or two pairs of pinnules and a terminal portion, all of which are lobed and crenated (figs. 262, 263). The fourth and succeeding leaves are pinnate like the third, but with more pinnæ (figs. 264, 265). A11 of these early leaves are broadest at the base and they vary from deltoid to broadly lanceolate in shape. But in outline of the pinnæ and pinnules the third and fourth leaves are exactly like the mature leaf. They are thin and fragile, consisting only of upper and lower epidermis (figs. 254, 266) and one layer of spongy parenchyma (fig. 253). Stomata are numerous in the lower epidermis of each leaf, especially on the pinnate leaves. A few stomata occur scattered over the backs of the petioles (fig. 268). The margin of the leaf is strengthened by long, narrow, indurated cells underlying the epidermis (fig. 251).

The first two leaves are devoid of hairs of any kind. Hairs begin to occur on the third leaf, but the fourth shows three kinds of trichome structure-glands, moniliform hairs, and acicular hairs. A few glands (fig. $258, u$ ) occur, thinly scattered on the upper and lower surfaces of lamina and rachis, but they are more plentiful on the petiole. Each one consists of one to three large, swollen cells. They probably represent the glandular hairs of the adult. Moniliform hairs (fig. 258, $m$ ) consist of three or four cells, each of which is broader above and narrower below. They lie appressed to the leaf-surface. They are plentiful on both surfaces of the lamina and rachis, but there are none at all on the petiole. Acicular hairs like those of the adult leaf are plentiful all over the fifth leaf, and on the stem apex. They are four to seven cells long (commonly 4, 5, or 6), thick-walled, and curve outward from the surface of both the lamina and the petiole.

The mature petiole of the early leaves is slender, flattened above and rounded below (fig. 248). Under an uneven epidermis there is a cortex composed of two or three layers of large, thin-walled cells. In this are large intercellular spaces. A well-defined endodermis demarcates a cylindrical vascular bundle. In this is a stout transverse band of xylem, surrounded by phloem and a single layer of pericycle. The xylem consists of narrow spiral and scalariform tracheids.

As stated above, the first leaf is derived from two octants of the embryo, not from one alone, and grows always by a group of marginal initials. These undergo sectioning and halving as in the adult the leaves (fig. 250). The second leaf arises from the stem-tip. Its development has not been followed.

I have not determined how long it takes to obtain mature plants from spores. Forked stems are found after about one year. In some cases certainly another season intervenes before maturity is reached. Probably they never fructify before the third or fourth summer. 


\section{DISCUSSION OF RESULTS.}

We have restricted ourselves thus far to mere description of the development of Dennstadtia punctilobula. It remains to point out in order some general considerations suggested by the investigation.

\section{TAXONOMY.}

Whether our fern belongs in the Cyatheaceæ or the Polypodiaceæ should not be difficult to decide. The principal differences between the orders may be shown by a table:

\section{CyATHEACEE.}

Annulus a complete circle, oblique. Antheridium cover multicellular. Cushion of prothallus with bristles. Broad cells in continuous series in the rhizogenous line.

\section{Polypodiaces.}

Annulus surrounding three-fourths of sporangium, symmetrical.

Antheridium cover unicellular.

Cushion without bristles.

Rhizogenous cells separated by smaller cells.

In all of these points the plant now under discussion agrees with the Polypodiaceæ. But Bauke (1876) states for Dicksonia rubiginosa that its antheridium is cyatheaceous. Moore (1857) and recent writers place D. rubiginosa Kaulf. and Dicksonia punctilobula Willd. in the genus Demstedtia. Gwynne-Vaughan (1903) further shows that D. rubiginosa has a complicated solenostelic stem. If Moore and his followers are correct, the character of the antheridium must cease to stand as a distinction between the two orders. This point is much in need of investigation in other Dicksonias and Dennstædtias, as well as in Davallia, Lindsaya, Microlepia, and the allied genera. Cyatheaceous root-structure I have observed in Cibotium regale. But we need to know the arrangement of rhizogenous cells in the other genera just named. A knowledge of these points is especially needed for the Melanesian Dennstadtia flaccida, the type of the genus. For it may yet develop that our North American fern is not referable to the same genus with $D$. flaccida. In that case we should have to adopt the generic name Sitobolium Desv. The point can only be settled after a careful examination of $D$. Alaccida throughout its structure and life-history. The removal of our fern from the genus Dicksonia L'Herit. is generally agreed upon, and is quite sure to stand. The use of the name Dicksonia certainly leads to confusion, as when a recent European writer speaks of our plant as a "tree-fern."* But further studies along the lines indicated are needed to fully establish the position. Indeed, it is not impossible that such a comparison would break down the feeble barrier between Cyatheaceæ and Polypodiaceæ by showing a series of connecting links. 
STELAR MORPHOLOGY.

Some views already published (1906) on this point may be repeated here. The development of the seedling stem supports the idea of Jeffrey and Boodle of the phylogeny of the fern-stem. We first have the protostele, then the ectoploic siphonostele, and finally the solenostele. But there is no evidence of any influence of the tissues outside the vascular tube upon those inside. Each interior tissue is established before it comes into communication with its external homologue.

\section{HOMOLOGY OF TISSUES.}

Indeed, homology of tissues can not be determined either by continuity or by origin in the meristem. We may not homologize the medulla of Dennstadtia with the central xylem of Lygodium simply because both arise from the inner ends of the segments of the stem-initial. Much less could we identify the inner endodermis of Dennstadtia with any of the xylem of Lygodium. On the other hand, the continuous endodermal layers of root, stem, and leaf in Dennstadtia must be considered as one homogeneous tissue. But in the root-tip the endodermis arises just outside and the pericycle just inside the second periclinal wall in each segment. In the stem the endodermis is the result of the last (second) periclinal division in a layer of plerome which also gives rise to the pericycle. The same is true of the leaf-an organ which grows at first by a threesided initial, then by a two-sided, and finally by a group of marginal cells. In Dennstadtia punctilobula, therefore, tissues are homologous which have the same structure and function, in spite of their differences of origin (cf. Gocbe1, 1900).

The same conclusion is indicated by the long-familiar fact that in roots of dicotyledons the undoubtedly homologous primary tissues arise from at least five different types of root-tip (De Bary, 1884, p. 12). Indeed, radically different types of tip may occur in allied-genera, as in Nymphaa and Nuphar. And it is not impossible that different types may be found in different roots of the same individual plant. The recent discussion of stem-tips raises the same point in questioning the validity of Hanstein's tissue layers (Schoute, 1903, etc.). It seems reasonably certain that Hanstein's layers are not of very wide application. In the face of so much evidence, also, Van Tieghem's denial of an epidermis to the roots of ferns, monocotyls, and Nymphæaceæ becomes quite valueless. These plants have just as real an epidermis as have others.

\section{INDEPENDENCE OF MERISTEM AND MATURE TISSUES.}

The fact is that the development and structure of the mature tissues are to a large extent independent of the development and structure of the meristem from which they are derived. The lowest plant with celldivision in three planes is essentially meristematic. From such a begin- 
ning meristems have had a regular and orderly phylogenetic history ( $c f$. Bower, 1889). From the meristem a more or less homogeneous parenchyma is directly derived. Very soon, however, farther differentiation occurs in the older parenchyma-the parts farthest removed from apical meristem. This differentiation has also been modified in course of time in response to the environment and the needs of the plant. But there is no reason to suppose that the changes in the meristem should have any direct relation to those in the older portions. Meristem develops from a growing point and its structure is influenced largely by the shape, size, number, and position of the initial cells. Mature tissues develop from below upward, and are shaped out of meristem in response to stimuli which come chiefly from the more mature cells. While this independence of meristem and mature tissues seems plainly indicated by a comparison of plants as they commonly occur, it is also capable of experimental investigation. Some of the most promising material for this purpose would be in the genera Gleichenia ( $c f$. Boodle, 1901) and Lindsaya ( $c f$. Tansley and Lulham, 1902). But this is a subject which has yet to be followed out.

Synonymy of generic names, and list of type species on strict Linnaan priority.

I. Polypodium-Linnæus, 1753-Type: P. lanceolatum (first species named.)

2. Dicksonia-L'Heritier, I 788 - Type: $D$. culcita (or $D$ arborescens).

3. Aspidium-Swartz, 1800-Type: A. articulatum (fide Underwood, 1899).

4. Dennstadtia-Bernhardi, 1800-Type: D. faccida = Trichomenes faccidum Forst.

5. Nephrodium-Michaux-Date and type uncertain. Cf. Underwood, 1899, p. 265.*

6. Sitobolium-Desvaux, 1827-Type: S. punctilobum.

7. Sitolobium-J. Smith, 184 I-Type: $S_{\text {. punctilobum. }}$ pum.

8. Litolobium-G. Kunze, 1848 -Type: L. punctilobum.

9. Adectum-Link, I84I-Type: A.pilosiusculum.

*Cf. Davenport in Rhodora, $4: 158 \mathrm{ff}$., Aug. 1902. 


\section{SYNONYMY.}

Nephrodium punctilobulum Michaux, 1803, 2: 268.

A spidium punctilobulum Swartz, 1806, p. 6o. punctilobum Willdenow, I810, 5:279.

Pursh, I8I $4,2: 664$.

Polypodium pilosiusculum Muhlenberg, in Willd., 1809 , p. 1076.

Willdenow, in Schkuhr, 1809, p. 125.

Dicksonia pilosiuscula Willdenow, 1809, p. 1076; 1810, 5: 484.

Poiret, i 8 I I, 2: 472.

Pursh, I8 I 4, 2:67I.

Nuttall, 1818, 2: 253 .

not Raddi, 1825, p. 63 .

Sprengel, 1827, 4: 122.

Darlington, I837, p. $5^{8} 4$; also ed. II.

Hooker, $1840,2: 264$.

Bigelow, 1814, p. 254; 1824, p. 397; 1840, p. 424.

Eaton, 1836, p. 277.

Eaton and Wright, 1840, p. 224.

Torrey, 1843, 2: 502 .

Wood, 1846 , p. $633 ;$ i 864 , p. 820 .

Macoun and Burgess, 1884, p. 222.

Gray, I889, p. 691, pl. 18.

Macoun, I890, p. 285.

Wilson, I897, p. 8.

Parsons, I899, pp. II4-I I9.

Clute, I90I, p. 230.

Waters, 1903, pp. 64, 68, 286-290.

Eastman, 1904, p. 64.

Dicksonia pubescens Schkuhr, 1809, p. 125, pl. 131.

Presl, 1836, p. 136 .

Sitobolium punctilobum Desvaux, 1827, p. 262-263.

Sitolobium punctilobum J. Smith, $1846 a ;$ i $846 b$, p. 70 .

pilosiusculum J. Smith, I84I, p. 418 ; 1842, p. 434.

Adectum pilosiusculum Link, I841, p. 42 .

Dicksonia punctiloba Hooker, 1846, 1: 79.

Fée, 1850, p. 335 .

Lowe, 1867, 8: 123-124, pl. 42.

Hooker and Baker, I868, p. 54; 1874 .

Gwynne-Vaughan, 1901, p. 85 ; 1903, pp. 691, 730.

Litolobium [punctilobulum] Kunze, I 848 (1846), p. 88.

Dicksonia punctilobula Gray, I848, p. 628; 1856 ; 1858 , p. 595; 1859, p. 595; 1867, p.669, pl. II $; 1880$, p. 669.

Kunze, 1848, p. 88 (written in 1846 ); 18506, p. 249.

Darlington, 1853, p. 394 .

Mettenius, 1856, p. 105.

Provancher, 1862, p. 720 .

Ball, 1876 , p. 155 .

Williamson, 1878 , p. I 19, pl. 45.

Eaton, i 879, 1: 339-344, pl. 44 .

Fowler, fide Macoun and Burgess.

Underwood, $1888 ; 1893$.

Britton and Brown, 1896, 1: 12.

Chapman, 1860 , p. $597 ; 1883$, p. $597 ; 1897$, p. 635.

Dennstadtia punctilobula Moore, 1857, pp. $97,307$.

Lawson, 1864, p. 287; 1888, p. 233.

DeBary, 1884, p. 284.

Underwood, i $900 a, 1: 472$; $1900 c$, p. I 22.

Britton, 190I, p. 19.

Small, 1903, p. 18.

Keller and Brown, 1905, p. I4.

Dennstadtia punctiloba Hooker and Baker.

Christ, I 897, p. $3^{12}$.

Diels, I899, p. 217 . 


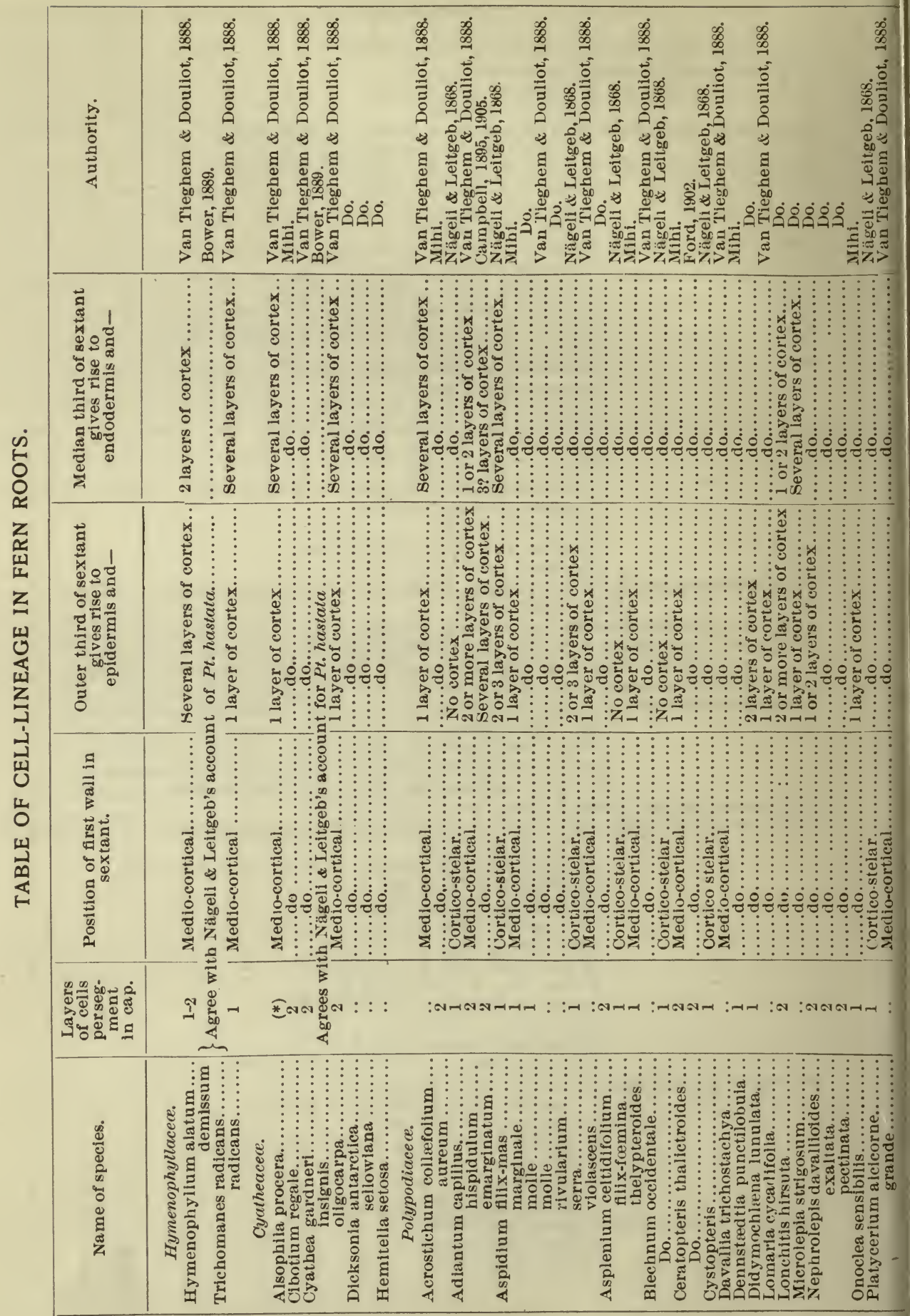




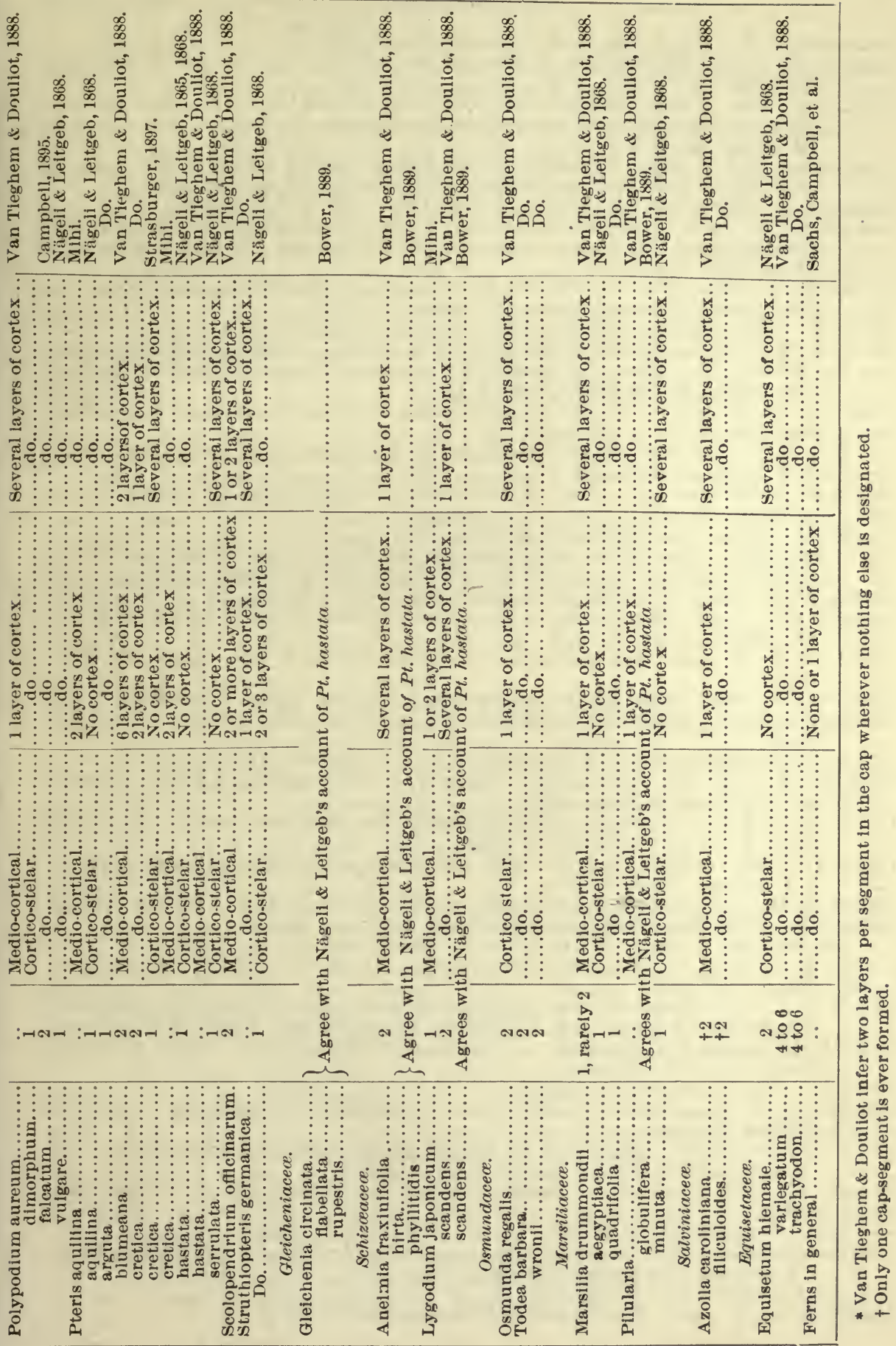




\section{BIBLIOGRAPHY.}

Atkinson, G. F. 1894. The Study of the Biology of Ferns.

BALL, E. H. 1876. The Indigenous Ferns of Nova Scotia, in Proc. and Trans. Nov. Scot. Inst. of Nat. Sci., 4: I55.

BAUKe, H. 1876. Entwicklungsgeschichte des Prothalliums bei den Cyatheaceen, verglichen mit derselben bei den anderen Farrnkräutern, in Jahrb. f. wiss. Botanik, 10: $49-116$, pls. 6-10.

BERNHARDI, D. I. I. I800. Tentamen alterum filices in genera redigendi, in Schrader's Journal für die Botanik. Göttingen, vol. 2, parts 1 and 2, pp. 12 I-136.

Bigelow, J. 1814-18 †0. Florula Bostoniensis, ed. I, I8I4; II, I824; III, 1840 .

Boodle, L. A. 1901. Comparative Anatomy of Hymenophyllaceæ, Schizæaceæ, and Gleicheniaceæ. II. On the anatomy of the Schizæaceæ. In Annals of Botany, 15: $359-423$. June.

BowER, F. O. I889. The Comparative Examination of the Meristems of Ferns as a Phylogenetic Study, in Annals of Botany, 3: 305-393

BRICK, C. 1897. Review of Wilson, 1897, in Botan. Jahrsber. 1897, 1: 470.

Britton, N. L. Igor. Manual of the Flora of the Northern States and Canada, p. I9. - and Brown, AD. 1896. An Illustrated Flora of the Northern United States, Canada, and the British Possessions, 1: 12.

Campbell, D. H. 1887. The Development of the Ostrich Fern, in Mem. Boston Soc. Nat. Hist., 4: $17-52$, pls. 4-7.

1895; 1905. The Structure and Development of the Mosses and Ferns. Macmillan, New York: ist and $2 \mathrm{~d}$ ed.

Chapman, A. W. 1860-1897. Flora of the Southern United States; ed. I, 1860; II, I883; III, 1897.

Christ, H. 1897. Die Farnkräuter der Erde, Jena.

Chrysler, M. A. 1904. The Development of the Central Cylinder of Aracea and Liliaceæ, in Botanical Gazette, 38: $161-184$, pls. XII-Xv. Sept. 23, 1904.

Clute, W. N. Igor. Our Ferns in their Haunts. New York; 332 pp.

ConARD, H. S. 1906. Morphology of Fern Stem, in Johns Hopkins Circulars, pp. 9598. May.

Copeland, E. B. 1902. The Mechanism of Stomata, in Ann. of Bot., 16: 327-364, pl. 13. June.

DARLington, Wm. I 853 . Flora Cestrica; ed. I, I837; III, I853. Philadelphia.

DAVENPORT, G. E. Dicksonia pilosiuscula var. cristata, in Rhodora, 2: 220-226. Not seen.

1905. Reversions and their Fluctuations, in Fern Bulletin, 13: 106-107.

DE BARY, A. 1877; 1884. Comparative Anatomy of Phanerogams and Ferns. German ed., 1877; English trans., I 884 .

Desvaux, N. A. 1827. Prodrome de la Famille des Fougères, in Mém. Soc. Linn. Paris, 6: $171-337$. See pp. $262-263$.

Diels, L. 1899. Polypodiaceæ in Engler and Prantl's Natürlichen Pflanzenfamilien, 1-4: 217-218. Sept. 12, I899.

Eastman, H. 1904. New England Ferns and their Common Allies. Boston. 16r pp. EAton, A. I836. Manual of Botany for North America. Albany.

- and Wright, J. I840. North American Botany; ed. vili.

EATON, D. C. 1879. The Ferns of North America. 2 vols., I879-1880, 81 plates. Salem, Mass.

FÉE, A. L. A. I850. Genera Filicum (Cinquième Mémoire sur la Famille des Fougères). Exposition des Genres de la Famille des Polypodiacées. Paris and Strasbourg.

Ford, S. O. rgoz. The Anatomy of Ceratopteris thalictroides, in Annals of Botany, 16: $95-122$, pl. 6. March.

Fowler. New Brunswick Catalogue.

Gilbert, B. D 1905. Observations on North American Pteridophytes, II, in Fern Bulletin, 13: 100-104.

Gray, AsA. I848-r 889. Manual of the Botany of the Northern United States; ed. I, I848; II, I856; III, I858; IV, 1859: V, I880; VI, I 889 .

Goebel, K. 1887. Outlines of Classification and Special Morphology, English translation.

- 1900. Organography of Plants. Transl. by Balfour, 1: 14-17.

GWYNNE-VAughan, D. T. I901. Observations on the Anatomy of Solenostelic Ferns I. Loxosoma. In Annals of Botany, 15: 71-99.

- 1903. Ditto, II, 1. c., 17: 689-743.

HaberlandT, G. 1904. "Physiologische Pflanzenanatomie, ed. 3. 
Hooker, W. J. 1840. Flora boreali-americana, 2: 264. London.

1846. Species Filicum, vol. I.

and BAKER, J. G. 1874. Synopsis Filicum, ed. I, I868; II, 1874.

JANSE, J. M. I895. Les endophytes radicaux de quelques plantes Javanaises, in Ann. du Jardin Botanique de Buitenzorg, 14: 53-201, pl. v-xv. (Vol. 14 is dated I897.)

Jeffrey, E. C. 1897. The Morphology of the Central Cylinder in Vascular Plants, in Report of the British Assoc. for the Adv. of Sci. I 897, pp. 869-870.

Johnson, D. S. I898. On the development of the leaf and sporocarp in Marsilia quadrifolia L., in Annals of Botany, 12: 119-147. June.

Keller, I., and Brown, S. 1905. Handbook of the Flora of Philadelphia and Vicinity. Phila. Bot. Club.

KNY. 1875. Die Entwickelung der Parkeriaceen dargestellt an Ceratopteris thalictroides Brongn., in Nova Acta d. Leopoldinisch Carolinische Akademie der Naturforscher, 37: 1-80, pl. 18-25.

Kunze, G. 1848. In Silliman's American Journal of Science and Arts, 2d series, 6: $80-89$. "Notes on some ferns of the United States," written 1846 .

1850a. Einige Bemerkungen über Dicksonia, in Botan. Zeitung, 8: 57-62.

1850b. Index Filicum (sensu latissimo), in Linnæa, 23: 209-323.

LACHMANN, P. I877. Structure et croissance de la racine des Fougères, in Bull. Soc. bot. Lyon. Not seen.

1885. Recherches sur la morphologie et l'anatomie des Fougères, in Comptes Rendus, 101: 603. Not seen.

1887. Structure et croissance de la racine des Fougères, et l'origine des radicelles. Bull. Soc. bot. de Lyon.

Lawson, Geo. I864. Synopsis of Canadian Ferns and Filicoid Plants, in Trans. Bot. Soc. Edinb., 8: 20-50. vidi. Also in Edinb. New Philos. Journ., N. S., 19:1021 16,273-291, 1864; Canad. Naturalist, N. S., 1: 262-380, 1864. Not seen.

1888. The Fern Flora of Canada. A. W. Mackinlay, Halifax. Not seen.

L'Heritier de Brutelle, C. L. 1788. Sertum Anglicum. Folio, 36 pp., 34 plates. Not seen.

LiNK, H. F. 1841. Filicum species in horto regio botanico Berolinensi cultæ. $179 \mathrm{pp}$. Not seen.

LinNeUS, C. 1753. Species Plantarum.

Lowe, E. J. 1867. Ferns: British and Exotic, vol. 8. London.

MACoun, J. 18yo. Catalogue of Canadian Plants. Part v, Acrogens. Geological and Natural History Survey of Canada, vol. 2. Montreal.

and Burgess, F. W. 1884. Canadian Filicineæ, in Trans. Roy. Soc. Canada, 2: $163-227$; sec. 4

MAxON, W. R. I899. A variety of Dicksonia, in Fern Bulletin 7: 63-64. Not seen.

Mettenius, G. H. 1856 . Filices horti botanici Lipsiensis.

Michaux, A. Hort. med. Paris. Cat. not seen.

I803. Flora Boreali-Americana, 2: 268.

Moore, Thos. I857. Index Filicum.

NÄGeli, C., and Leitgeb, H. 1865. In Sitzber. baier. Akad. Wiss.

I868. Entstehung und Wachsthum der Wurzeln in Beitr. $z$. wiss. Botanik, Hft. IV, pp. $74^{-160,}$ pls. XI-XXI.

Newman, E. 1841-1851. The Phytologist, 5: 236, fide Moore, 1857.

Nuttall, Thos. I818. The Genera of North American Plants, and a catalogue of the species to the year 1817. Philadelphia.

Parsons, F. T. 1899. How to Know the Ferns. New York.

PoIret, J. L. M. i8ir, Article "Dicksonia," in Lamarck, Encyclopédie Méthodique Botanique. Supplement, tome II, p. 472. Paris, I8II.

Prantl, K. I875a. Hymenophyllaceen. Leipzig.

$1875 b$. Verzweigung des Stammes, in Flora, No. 34. Not seen.

PRESL, K. B. I836. Tentamen pteridographiæ, seu genera filicarum præestim juxta venarum decursum et distributionem exposita. Prag.

Provancher, L. i862. Flore Canadienne. Quebec. 842 pp. Not seen.

PURSH, F. I8I4. Plants of North America, 2: 664.

RADDI, J. 1825. Plantarum Braziliensium nova genera et species novæ vel minus cognitæ. Florentiæ.

Russow, EDM. 187 I. Vergleichende Untersuchungen über die Leitbündelkryptogamen. in Mém. de l'Acad. Imp. de St. Pétersbourg, sér. viI, 19:80.

Sachs, I. 1875. Text-book of Botany. English transl. 
Sadebeck, R. 1873. In Verh. Bot. Ver. Prov. Brandenburg, 15.

- 1874. Farnblatt.

1878. Vascular Cryptogams in Schenck's Handbuch.

1898. Pteridophyta in Engler and Prantl's Natürlichen Pflanzenfamilien, 1-4 A.

Schkuhr, C. I809. Vier und zwanzigste Klasse des Linné'schen Pflanzensystems, oder Kryptogamische Gewächse.

Schoute, J. C. 1903. Die Stelär-theorie. Jena.

Small, J. K. 1903. Flora of the Southeastern United States. New York.

Sмiтh, J. I84r. Enumeratio Filicum Philippinarum, in Hooker's Journ. of Botany, 3: $392-422$.

1842. An Arrangement and Definition of the Genera of Ferns, with observations on the affinities of each genus, in Hooker's London Journ. of Botany, 1: 419-438. $1846 a$, in Bot. Mag. Comp., 36 . Not seen.

$1846 b$. Catalogue of the Ferns grown at Kew. Not seen.

SPkENGEL, K. 1827. Caroli Linnaei Systema vegetabilium, vol. 4. Not seen.

Strasburger, E. 1807 . Das Botanische Practicum, ed. 3.

Strasburger, Noll, etc. I 898 . Text Book of Botany, English translation.

Swartz, O. i 800 . Genera et Species Filicum, in Schrader's Journ. für die Botanik, 2: $1-120$.

1806. Synopsis Filicum.

Tansley, A. G., and Lulham, R. B. J. 1902. On a new type of Fern-stele, and its probable phylogenetic relations, in Annals of Botany, 16: 157-164. March.

Тномає, K. i886. Blattstiele der Farne, in Jahrb. f. wiss. Bot., 17: 129.

Torrey, J. 1843. A Flora of the State of New York. Albany. 2: 502.

UNDERWOOD, L. M. 1888; 1893; 1900c. Our Native Ferns and their Allies. Ed. I, 1888; VI, 1900.

1899. A Review of the Genera of Ferns proposed prior to ${ }_{1832}$, in Mem. Torr. Bot. Club, 6: No. 4 .

1 g0oa. Article "Dennstædtia" in Bailey, Cyclopedia of American Horticulture, 1: 472.

1900b. Article "Dicksonia," 1. c., p. 480.

VAN Tieghem, Ph., and Douliot, H. 1888. Recherches comparatives sur l'origine des membres endogènes dans les plantes vasculaires, in Ann. Sci. Nat. Bot., sér. 7, 8: 127-132, 435-438.

Vines, S. H. I894. Text Kook of Botany.

WATERS, C. E. I903. Ferns. A manual for the northeastern States, with analytical keys based on the stalks and on the fructification. Holt, New York. 1903. $C f$. pp. $286-290$.

Willdenow, C. L. 1809. Enumeratio plantarum horti regii botanici Berolinensis. Berlin.

I8ro. Species plantarum. Ed. Iv.

Williamson, J. I878. Ferns of Kentucky. Louisville.

WrLson, F. 1897. "Dicksonia pilosiuscula," in Asa Gray Bulletin, 5: 7-9. Not seen.

WooD, A. I 846 . Manual of Botany; editions of 1846 and 1864 . 
EXPLANATION OF PLATES.*

Key to index-letters on figures (except figs. 47-51).

$a$, initial cell.

$c$, cortex.

$c j$, conjunctive parenchy ina.

$e$, epidermis.

$f$, fundamental tissue.

$h$, hypodermis.

$i$, rhizogenous cell.

ic, inner fundamental tissue.

$i c j$, inner conjunctive $\mathrm{p}$ is renchyma.

in, inner endodermis. ip, inner pericycle.

$i p h$, inuer phloem.

is, inner sclerenchyma.

ist, inner starchy tissue.

$n$, endodermis.

$p$, pericycle.

$p a$, parenchyma.

ph, phloem.

$p l$, plerome.

pph, protophloem.

$p x$, protoxylem.

\author{
$r$, root. \\ $r h$, root-hair. \\ $r t$, rootlet. \\ $s$, sclerenchyma. \\ $s a$, air-space. \\ $s p$, spiral tracheid. \\ $s t$, starchy tissue. \\ $t$ tracheid. \\ $v$, sieve-tube. \\ $x$, xylem.
}

Letters used varlously: $b, d, m, o, u, t r, 1,2,3$, etc.

Plate 1:

1. Habitat of $D$. punctilobula; Massachusetts. Photo by C. E. Waters, Ph.D.

2. Leaves as they grow. From Waters, 1903 , by courtesy of the author and publishers

Plate 2:

3. Rhizome, natural size, showing fork, leaf bases, and leaf-shoots.

4. Leaf-bud with two unequal leaf-shoots, natural size. 3 and 4 from photo by C. E. Waters, Ph.D.

5. Portion of pinna showing pinnules, lobes, crenations, sori, and hairs. $\times$ about 10. From Waters, 1903, by courtesy of the author and publishers.

Plate 3:

6-8. Diagrams showing distances between rootlets, natural size.

9. Diagrammatic projection of a piece of stem $5 \mathrm{~cm}$. long, including apex, with figures to indicate the number of roots attached to each eighth of the circumference.

10-13. Diagrams of divisions of rost-cap segment as seen from distal side.

14. Diagrammatic longitudinal section of root-tip, showing the origin of the various tissues. Walls numbered in order of formation.

15-22. Diagrams of division in segments of root-initial. Walls numbered in order of formation.

Plate 4:

20-22. See above.

23. Root-tip in longitudinal section. $\times 210$.

24. Longitudinal section of an anomalous root-cap, showing two layers from one segment at point marked $*$. $\times 210$.

25-32. Successive transverse sections of a root-tip. 25, 26 in cap; 27-32 in root; $b$ indicates root-cap. Initial and second set of segments dotted. All in the same relative position. $\times 2$ I0.

Plate 5:

28-32. See above.

33. Transverse section of same root, o.1 $\mathrm{mm}$. farther up than $32 ; b$, root-cap. $\times 210$.

34. Rhizogenous cell, undivided, in transverse section of root. $\times 210$.

35. Rhizogenous cell, second division, in similar section. $\times 210$.

Plate 6:

36. Rhizogenous cell, third division. $\times$ г ro.

37. First division in rhizogenous cell; longitudinal radial section of root. $\times 210$.

38. Endodermis with rhizogenous cells, tangential view. Reconstruction from serial longitudinal sections of root. $\times 2$ ro.

39. Ditto: another root. $\times 210$.

40. Oblique tangential view of rhizogenous cell, showing its first three divisions. $\times 2$ I0.

41. Rootlet initial from longitudinal tangential section of root. $\times 210$.

42. Rootlet initial in transverse section of root; one cap-layer. Cells within the chain of arrows have arisen by proliferation of cortex. $\times 210$.

43. Ditto; two cap-layers, $b$, and digestive layer of cortex, $o$. $\times 210$.

44. Part of transverse section of nearly mature root. $\times 210$.

45. Transverse section of stele of fully mature root. $\times 2$ Io.

46. Part of transverse section of old root with outer layers shedding off. $\times 100$.

*All figures are of Dennsactdtia punctilobula unless otherwise stated in the descrlption. 
Plate 7:

47. Root-tip of Aspidium marginale, longitudinal section; $a$, first periclinal wall; $b$, second periclinal; $e$, endodermis. $\times 210$.

48. Root-tip of Aspidium molle, longitudinal section; $e$, endodermis. $\times 2$ ro.

49. Root-tip of Didymochlana lunulata, longitudinal section; $e$, endodermis. $\times 210$.

50. Root-tip of ceratopteris thalictroides, longitudinal section. $\times 2$ ro.

5I. Root-tip of Onoclea sensibilis, longitudinal section; $e$, endodermis. $\times 210$.

52. Cortex of root of Dennscetdtia punctilobula, showing mycorhiza, 0 ; transverse section of root. $\times 210$.

53. Ditto. Longitudinal section. Entrance of fungus through a root-hair. $\times 210$.

54. Rootlet, transverse section. Pericycle dotted; sextant walls heavy. $\times 210$.

55. Junction of pericycle of root and rootlet. $\times 210$.

56. Junction of xylem of root and rootlet; longitudinal radial section of root. $\times 200$.

57. Ditto; tangential to rootlet. $\times 200$.

PLATE 8:

58. Two tracheids from the junction of the vascular bundles of root and stem. Macerated and teased out. $\times 210$.

59. Young root in longitudinal section of stem apex. From point marked 3 in fig. 70. $\times 210$.

6o. Longitudinal section of older root, about to pass out from stem; $b$, root-cap. From point marked 4 in fig. $70 . \times 210$.

61. Junction of root shown in fig. 60 with stem bundle. $\times 210$.

62. Sharply bent tracheid at junction of root and stem, from same section as fig. 99.

Plate 9: $\times 2$ 10.

63. Part of transverse section of stem. Area included in dotted lines at 2 in fig. 97 .

64. Part of longitudinal section of stem. Area included in dotted line 11 in fig. 70. 65. Ends of sieve-tubes of stem; macerated and teased.

66. Diagram of node; longitudinal section of stem and leaf-base; $b$, vascular bundle.

Plate IO:

67. Rhizome, transverse section. Photomicrograph.

68. Vascular bundle of petiole, transverse section. Photomicrograph.

69. Rachis of leaf, transverse section. Photomicrograph.

Plate i I:

70. Diagram of stem apex, longitudinal section. 1,9 , dotted outlines of leaf rudiments, showing their position relative to the stem apex. $2,3,4,7,8$, location of root-tips of various ages ( $c f$. figs. 59,60 ). 5 , beginning of protophloem. 6, point where endodermis and pericycle are separated. 10 , beginning of lignification in xylem. I1, area drawn in fig. 64 .

71. Stem-initial in transverse section. $\times 210$.

72-75. Segmentation and sectioning in the apex shown in fig. 7r. Segments numbered in order of age.

76. Isolated cells of sclerotic medulla; macerated and teased.

77. Ditto.

78. End of scalariform tracheid of stem; macerated and teased.

79. Ditto.

80. Isolated cells of sclerotic cortex of stem; macerated and teased.

81. Isolated cells of conjunctive parenchyma of stem; macerated and teased.

82. Vascular bundle of stem and leaf, with leaf-shoot dissected out and viewed from the side; $o$, leaf-gap; $m$, leaf-shoot; $t r$, leaf-trace; $u$, anterior end of portion of vascular bundle of stem. Drawn from nature by Miss M. E. Rogers.

Plate 12:

83-87. Diagrams of successive cross-sections of a fork of a stem, with ventral leaf. Dotted line indicates boundary between sclerotic and starchy tissues; vascular bundle section-lined; $t r$, leaf-trace.

88-92. Diagrams of successive cross-sections of rachis, showing departure of rib of pinna. Dotted line bounds sclerenchyma; solid line is endodermis; xylem is section-lined; $b$, trace of pinna. Fig. 88 is lowermost, 92 uppermost. 
Plate 12, continued:

93-96. Diagrams of successive cross-sections of petiolar bundle giving off a leafshoot bundle. Conventional signs as in figs. $83-87 ; m$, leaf-shoot.

97. Diagrammatic cross-section of leaf-shoot, near its origin. Conventional signs as in figs. 88-92; 2 indicates part drawn in fig. 63.

98. Isolated tracheids of fork of stem. 99. Diagram of fork of stem, longitudinal section. Conventional signs as in figs. 100. Diagrammatic cross-section of node; stem to right. Conventional signs as in
figs. $83-87$.

I0I. Diagrammatic transverse section of base of petiole. Conventional signs as in figs. $88-93 ; d$, region of stomata.

102. Diagram of junction of root and stem, longitudinal section. Cortex and medulla section-lined.

Plate I3:

I03. Stem-initial with four segments, in transverse section, with leaf-rudiment, $d$, at left. $\times 2$ io.

104. Transverse section of stoma. After Copeland, 1902.

I05. Glandular hair of leaf, with two gland-cells. $\times 210$.

106. Longitudinal section of stem apex; heavy lines at right show boundary of vascular bundle; $d$, intercalary growth of hair; $u$, origin of hair. Composite. $\times 210$.

107. Protophloem in transverse section of stem near apex. $\times 2$ 10.

108. Transverse section of stem-bundle at margin of leaf-gap, showing continuity of inner and outer vascular tissues. $\times 2$ ro.

I09. Oblique transverse section of stem-initial, with leaf-rudiment $(b)$ in fourth segment. $\times 360$

110. Protophloem and earliest lignified xylem in transverse section of stem near

Plate I4: apex. See lettering on fig. 107.

111. Lower epidermis of leaf. $\times 2$ 10.

I12. Upper epidermis of leaf. $\times 210$.

113. Transverse section of leaf; chloroplasts diagrammatic. $\times 210$.

II4. Diagrammatic transverse section of rachis near summit; xylem shaded; $m$, parenchymatous region connecting with stomata; $t r$, trace of pinna.

115. Inner surface of indusium, near margin. $\times 210$.

116. Cavity parenchyma $(d)$ in transverse section of rachis. $\times 210$.

117. Ditto, in longitudinal section. $\times 210$.

118. Early stage of leaf-initial in transverse section of stem apex.

II9. Outer surface of indusium, $\times 2$ I0.

120. Inner surface of indusium, near base, with stomata. $\times 2$ ro.

121. Formation of leaf-initial in stem apex; later stage than fig. I18. Transverse section.

Plate I5:

122-127. Serial transverse sections of leaf-rudiment, showing transition from foursided to two-sided initial; 122 is through apex of rudiment, 127 through its base.

I28, I29. Longitudinal sections of stem apex with leaf-rudiment, taken $0.025 \mathrm{~mm}$. apart; $m$, region of stem-initial; $o$, leaf-initial; $b$, stem-initial.

130. Longitudinal section of leaf-rudiment in radial longitudinal section of stem. $\times 360$.

13I. Transverse section of two-sided leaf-initial, from a leaf with three pairs of pinnæ.

I 32-I34. Serial sections (obliquely sagittal) through one end of leaf-initial, showing segments and sections. From a leaf with four pairs of pinna.

135. Longitudinal section of leaf-initial; from a leaf with three pairs of pinnx.

136. Longitudinal section of leaf-tip; no pinnæ.

137. Surface section of leaf-tip with marginal initials.

Plate i6:

138. Longitudinal section of leaf with five pairs of pinnæ, showing loss of initial. Segments 1 and 2 formed successively on same side of apical cell. $\times 360$.

139. Sagittal section of leaf-rudiment with three pairs of pinnæ, becoming circinate. Heavy lines bound segments. 
Plate 16, continued:

140. Transverse section of rachis near apex of a leaf with three pairs of pinnæ and a single initial cell, showing sectioning of marginal cells, $m$.

141. Ditto; leaf with seventeen pairs of pinnze, growing by a group of marginal initials.

142-143. Transverse section of rachis of a leaf with seven pairs of pinnæ, showing cessation of division in marginal cells, $m$. Fig. 142 is between second and third pairs of pinne. $\times 360$.

144. Sagittal section of apex of a leaf with nine pairs of pinnæ, and growing by a group of marginal initials, $m$. $\times 360$.

145. Horizontal section of tip of pinna; $m$, growing point. From a leaf with eleven pairs of pinnæ.

146. Transverse section of pinna near apex; $m$, marginal cell.

147. Transverse section of leaf through a developing pinna; $m$, marginal cell. From same leaf as fig. 146.

Plate 17:

148. Horizontal section of developing pinnule; lobes and sinus.

149. Horizontal section of teeth of pinnule lobe, with developing veinlets (shaded).

150. Dorsiventral section of developing lamina.

151. Transverse section of leaf with rudiment of sorus on margin; $m$, mother-cell of first sporangium; $u$, indusium. $\times 2$ so.

152. Outline of pinnule of unfolding leaf. $\times 42$.

15.3. Surface of pinnule shown in fig. $15^{2}: m$, rudiment of stoma.

154. Longitudinal section of young sporangium; central cell just formed.

155. Transverse section of leaf-margin through a mature sorus; $d$, placenta; $u$, indusium. $\times 210$.

156. Oblique longitudinal section of developing sporangium with one central cell.

157. Longitudinal section of young sporangium; stalk and wall segments cut off; cap not yet formed. $\times 360$.

- $\quad 5^{8}$. Sagittal section of rudiment of sorus; $u$, indusium; 1,2 , successive sporangia. $\times 360$.

159-167. Sections of developing sporangia, showing stages as follows: Fig. I59, first cleavage in mother-cell; $d$; placenta. Fig. 160 , three-celled rudiment. Fig. I6r, first tapetal cell. Fig. 162, first tapetal layer complete (on right), leaving the archesporial cell. A three-celled rudiment at left. Fig. I63, division of the tapetal layer. Fig. 164, four archesporial cells in equatorial-plate stage, dividing to make eight. Figs. 165,166 , adjacent sections of two celled archesporium, dividing into four. Fig. 167 , spore mother-cells; tapetum degenerating.

Plate i 8:

16I-167. See above.

168. Tetrads, with fragment of tapetum.

169. Paraphysis arising from placenta.

170. Sagittal section of sporangium, showing the spore mother-cells just before synapsis.

I 7 I-I 72. Mature sporangia, from opposite sides.

I73. Mature paraphysis. $\times 360$.

174-175. Surface views of spores.

I76. Transverse section of stalk of sporangium.

177. Germinating spore. $\times 360$.

178. Three-celled protonema, short type.

179. Two-celled protonema. $\times 360$.

I80. Three-celled protonema, medium length.

181. Four-celled protonema.

182. Protonema with short basal cells. $\times 360$.

183. Six-celled protonema.

184. Three-celled protonema. Long type.

185. Five-celled protonema with two-sided initial. $\times 360$.

186. Base of a prothallus without protonema.

187. Protonema with two segments from initial. $\times 360$.

188. Five-celled prothallus without protonema. $\times 360$. 
Plate I9:

189. First longitudinal division in protonema.

190. Seven-celled protonema with two-sided initial. $\times 360$.

191. Side view of tig. 190.

192. Six-celled protonema; beginning of two-sided initial.

193. Same as fig. 192, showing length of rhizoids.

194. Apical growth established; one antheridium.

195. More advanced apical growth, drawn from a specimen plasmolyzed in salt solution in order to show the walls.

196. Long, six-celled protonema with two-sided initial just established.

197. Protonema with irregular apex.

198. Dwarf male prothallus. Westport, Maryland, September 25, 1905. Four prothallial cells, three antheridia.

199. Normal male, becoming cordate.

200. Group of marginal initials just established. $\times 210$.

Plate 20:

201. Papillar outgrowth on dorsal surface of female prothallus. $\times 210$.

202. Two-celled archegonial rudiment, $d$, in sagittal section of prothallus. $\times 360$.

203. Upper surface of prothallus; single initial giving place to a group. $\times 210$.

204. Apical growth with a group of initials; horizontal section. $\times 360$.

205. Vertical transverse section of prothallus, $0.05 \mathrm{~mm}$. back of notch, $i$. e., about the line $I_{-1}$ in fig. 204 .

206. Three-celled archegonial rudiment, $d$, in sagittal section of prothallus, cut along the line $2-2$ in fig. $204 . \times 360$.

207. Three-celled archegonial rudiment, $d$; first cleavage in neck-rudiment. $\times 360$. 208. Archegonial rudiment; neck and central cell. $\times 360$.

209. Cutting off neck canal-cell. $\times 360$.

210. Longitudinal section showing cleavage in neck cell. $\times 360$.

21 . Longitudinal section of young archegonium showing neck bending over. $\times 360$.

212. Surface view of neck of nearly mature archegonium. $\times 360$.

213. Ditto; young archegonium. $\times 360$.

214 . Archegonial rudiment, $d$, one cell. $\times 360$.

215. Longitudinal section of prothallus, showing neck canal cell with two nuclei. $\times 360$.

216. Formation of ventral canal-cell. $\times 360$.

21 7. Axial cells of archegonium complete; neck immature. $\times 360$.

2 I8. Neck canal-cell with three nuclei.

219. Mature archegonium; stained with iron hæmatoxylin. Ventral wall complete. $\times 360$.

220-222. Transverse sections of mature neck at summit, middle, and base, respectively. $\times 360$.

223. Egg-cell ready for fecundation.

224. Fertilized egg in longitudinal section of archegonium. Unsuccessful sperms in mucilage of neck. $\times 360$.

Plate 21 :

225. Longitudinal section of antheridial rudiment, one-celled. $\times 360$.

226. Ditto, two-celled. $\times 360$.

227. Surface view of a lobe of an old male prothallus. First division in central cell of antheridium above. $\times 210$.

228. Ditto; three-celled antheridium.

229. Side view of antheridium with long basal cell.

230. Antheridium nearly mature; vertical section. $\times 360$.

231. Rhizoids of female prothallus. $\times 2$ Io.

232. Optical section of three-celled antheridium; cleared in glycerin. $\times 360$

233,234 . Octants of embryo. Transverse sections of prothallus, 233 being $15 \mu$ anterior to $234 ; b$, stem-octant; $d$, rudiment of first leaf; $r$, root-quadrant; $u$, foot.

235, 236. Sagittal sections of embryo and calyptra, $25 \mu$ apart; $b$, stem initial; $d$, marginal cell of first leaf; $u$, foot.

237. Longitudinal section of old antheridium. 


\section{Plate 22:}

238. Transverse section of protostele below first leaf-gap. $\times 2$ ro.

239. Iransverse section of stem through the first leaf-gap, 0 . No inner phloem. Siphonostelic structure occurs o. I mm. higher up; $t r$, region of first leaftrace. $\times 210$.

240. Transverse section of siphonostele between first and second leaves.

24I. Transverse section of siphonostele midway between third and fourth leaves. 242-245. Serial transverse sections of the center of the stele at the origin of the inner endodermis. 24 I to 242 is $60 \mu ; 242$ to 243 is $10 \mu ; 243$ to 244 is

Plate 23: $20 \mu ; 244$ to 545 is $70 \mu$. All between third and fourth leaves. $\times 210$.

246. Sagittal section of young fern attached to prothallus; $m$, stem-initial; $o$, calyptra $r$, root; $t r$, first leaf; $u$, prothallus. $\times 75$.

247. Detail of transition from root to stem, from same series as fig. 246 ; $m$, anterior; $r$, posterior; $u$, upper part.

248. Slightly oblique transverse section of petiole of third leaf of sporeling; $d$, upper side. $\times 210$.

249. Glandular hair from leaf of adult plant. $\times 43$.

250. Transverse section of petiole of first leaf, showing sectioning of marginal cells. Endodermis dotted; $m$, marginal cell. $\times 360$.

251. Sinus of leaf-margin of seedling; dotted cells are epidermal. Surface view of cleared specimen. $\times 350$.

252. Young rhizoids and tips of mature ones from root of three-leaved sporeling of fig. $267 . \times 350$.

253. Optical section of spongy parenchyma of first leaf of sporeling; cleared in glycerine. $\times 350$.

254. Epidermis and developing stomata on sporeling leaf; $m$, stoma mother-cells. $\times 43$.

Plate 24:

255. Horizontal section of calyptra $(u)$ and embryo through root and rudiment of first leaf $(t r) . \quad \times 360$.

256. Diagrammatic cross-section of sporeling plant through third leaf-gap; $t r$, petiole $o$, leaf-gap.

257. Diagrammatic cross-section of stele and starchy cortex of sporeling stem at fourth leaf-gap; 0 , leaf-gap. $\times 75$.

258. Hairs of third leaf of sporeling No. 3 ; $b$, acicular; $m$, moniliform; $u$, glandular. $\times 350$.

259. First leaf of sporeling No. 2. $\times 5$.

260. Second leaf of same plant. $\times 5$.

261. Second leaf of plant No. 3. $\times 5$.

262. Third leaf of plant No.3. $\times 5$.

263. Third leaf of another plant. $\times 5$.

264. Fourth leaf of plant No.3. $\times 5$.

265. Fourth leaf of plant No. 4. $\times 5$.

Plate 25:

266. Lower epidermis of first leaf of sporeling. $\times 350$.

267. Three-leaved sporeling (No. I) with portion of prothallus $(u)$ still attached. I, 2, 3, first, second, and third leaves.

268. Surface view of petiole of second leaf of sporeling (No. I), with stoma.

269. Sporeling stem with roots and leaves cut off. Drawn from nature by Miss M. E. Rogers.

270. Forked stem of seedling. I, primary root leading up to the original simple stem. Drawn from nature by Miss M. E. Rogers. 

Plate 2

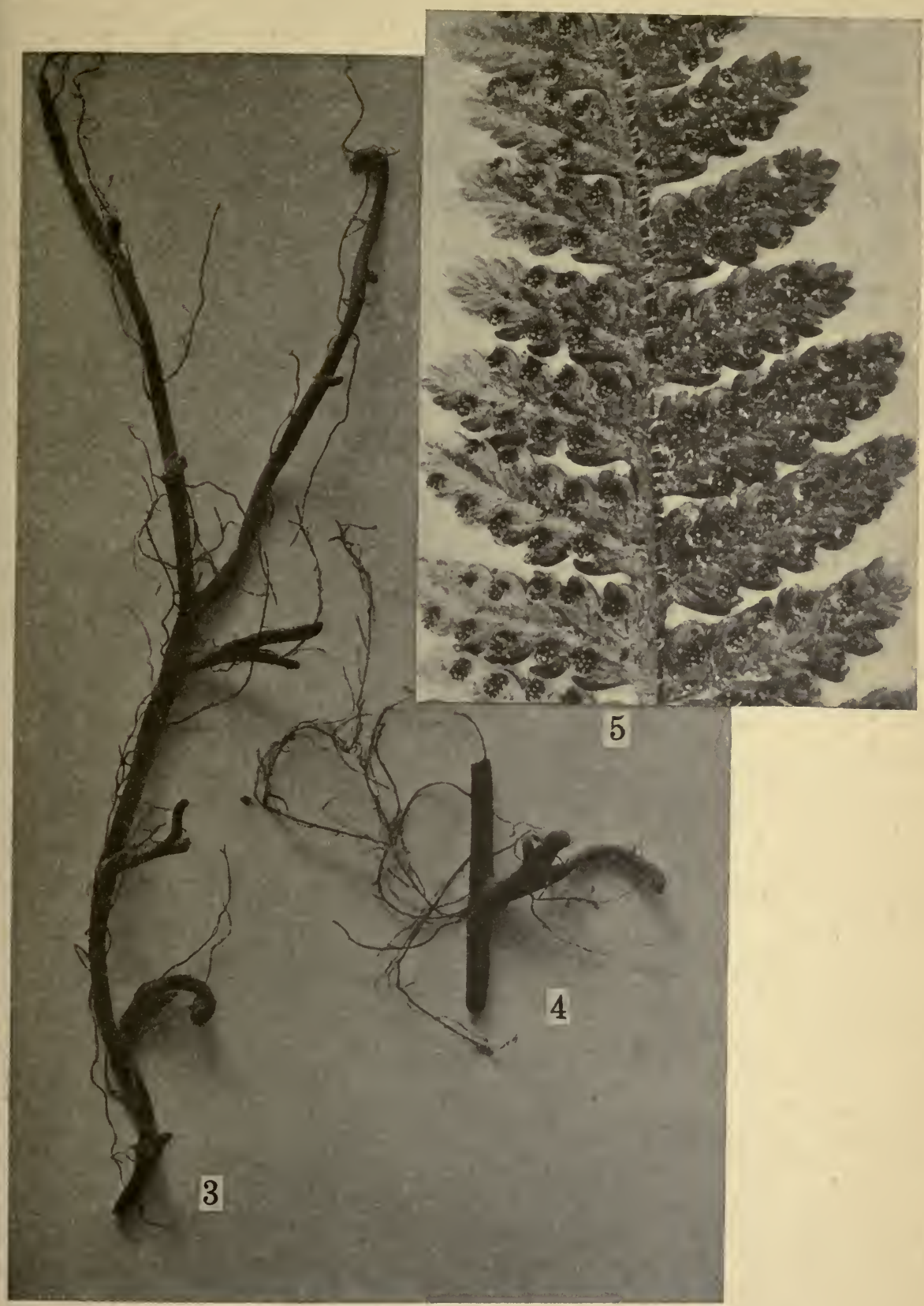

Fig. 3. Rhizome, natural size, showing fork, leaf-bases, and leaf-shoots.

Fig. 4. Leaf-bud with two unequal leaf-shoots, natural size.

Fig. 5. Portion of pinna showing pinnules, lobes, crenations, sori, and hairs. $\quad X$ about 10. 

Plate 3.
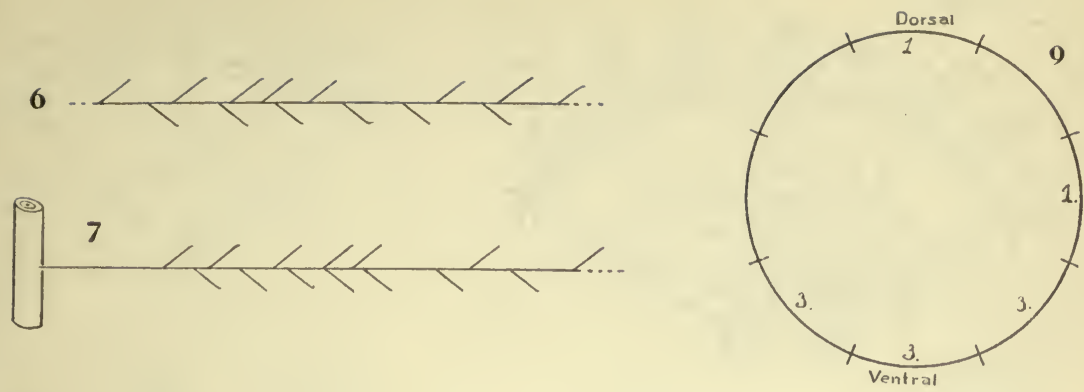

(2) 8
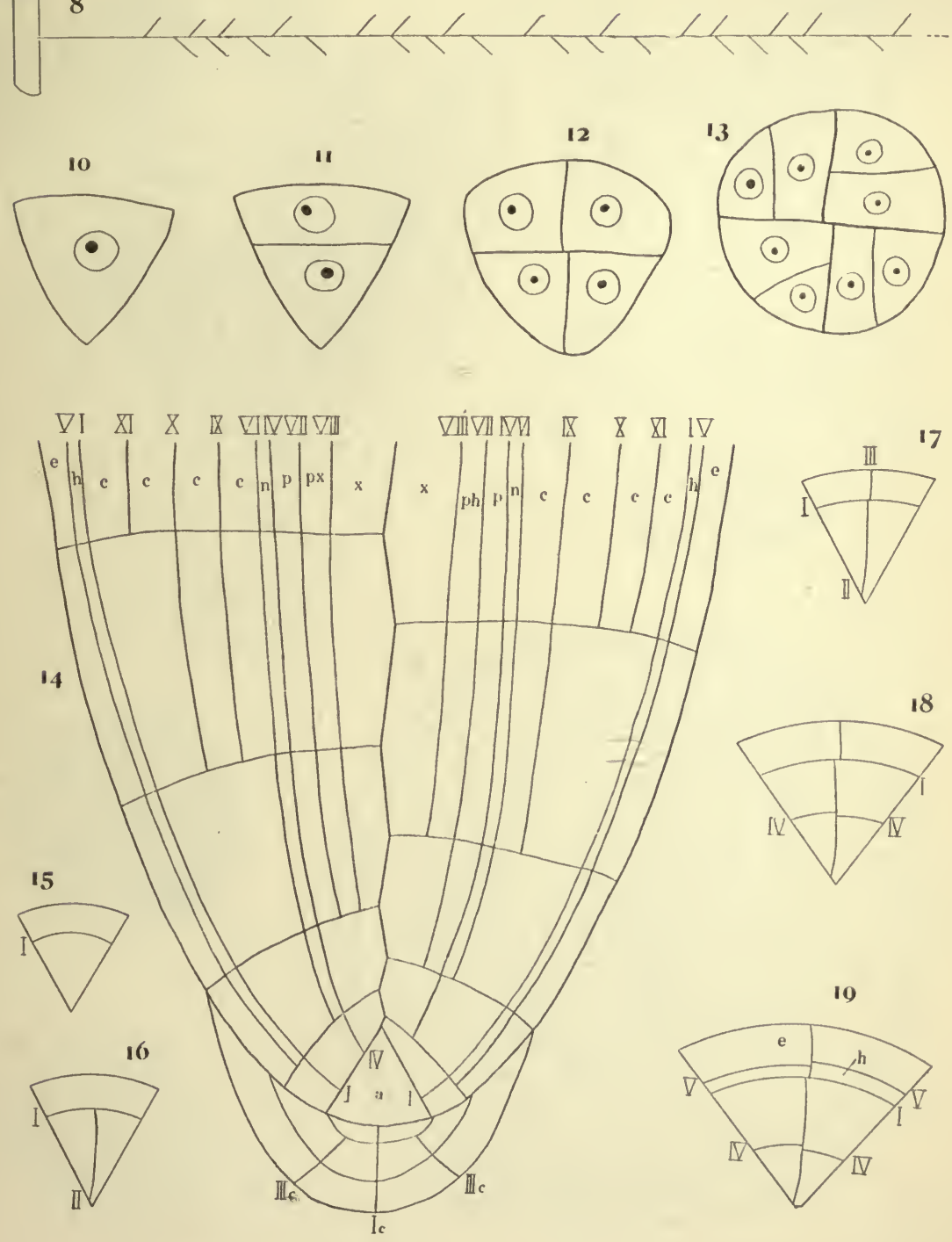



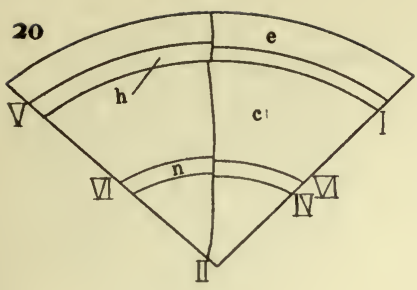

Plate 4.
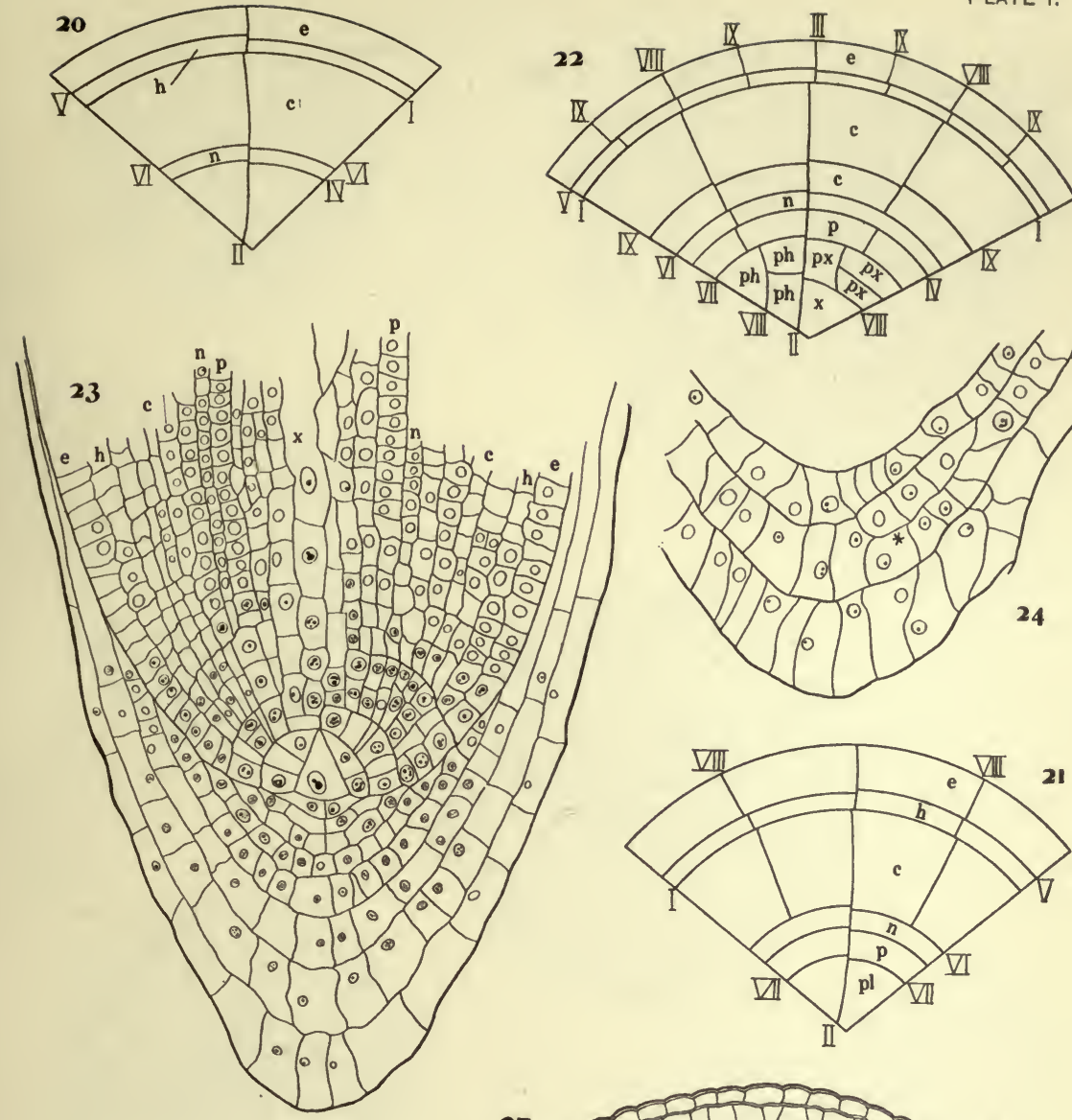

23 잉 100

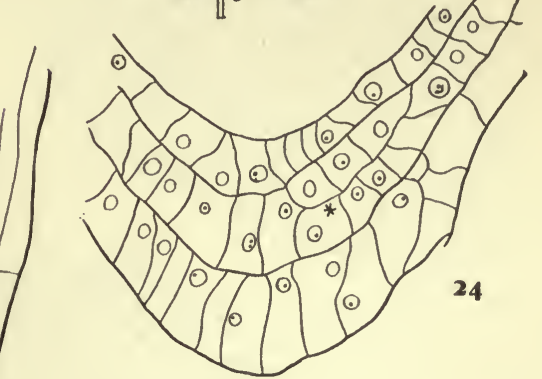

25
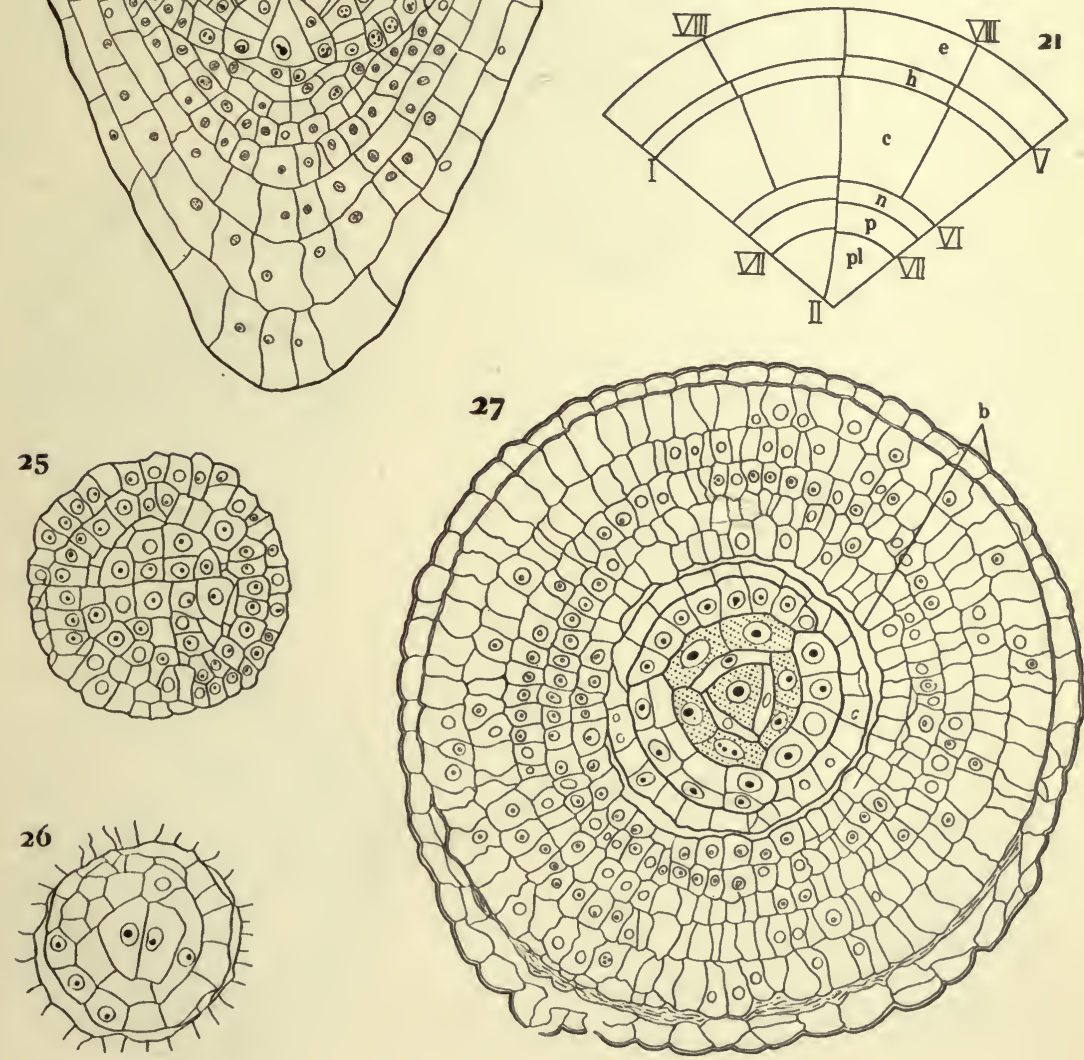

Plate 5.
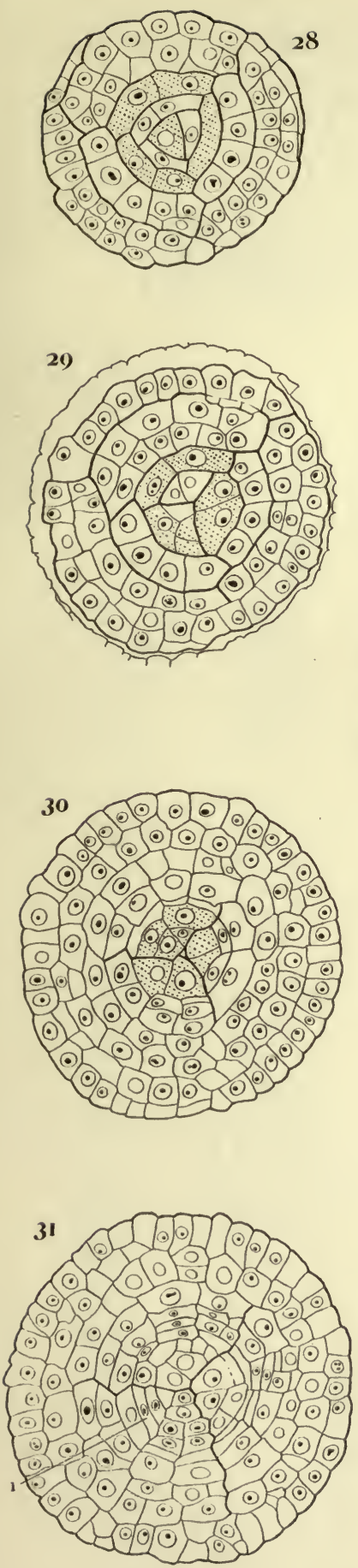

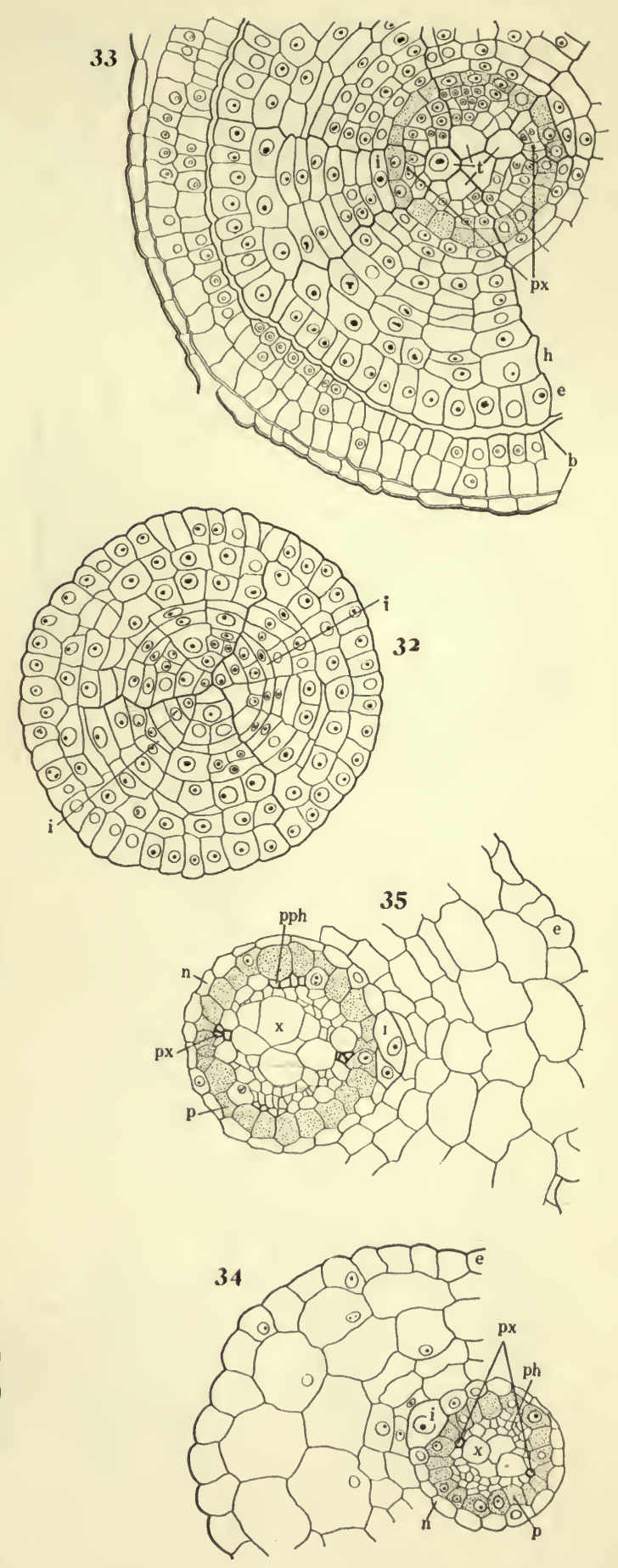



Plate 6.

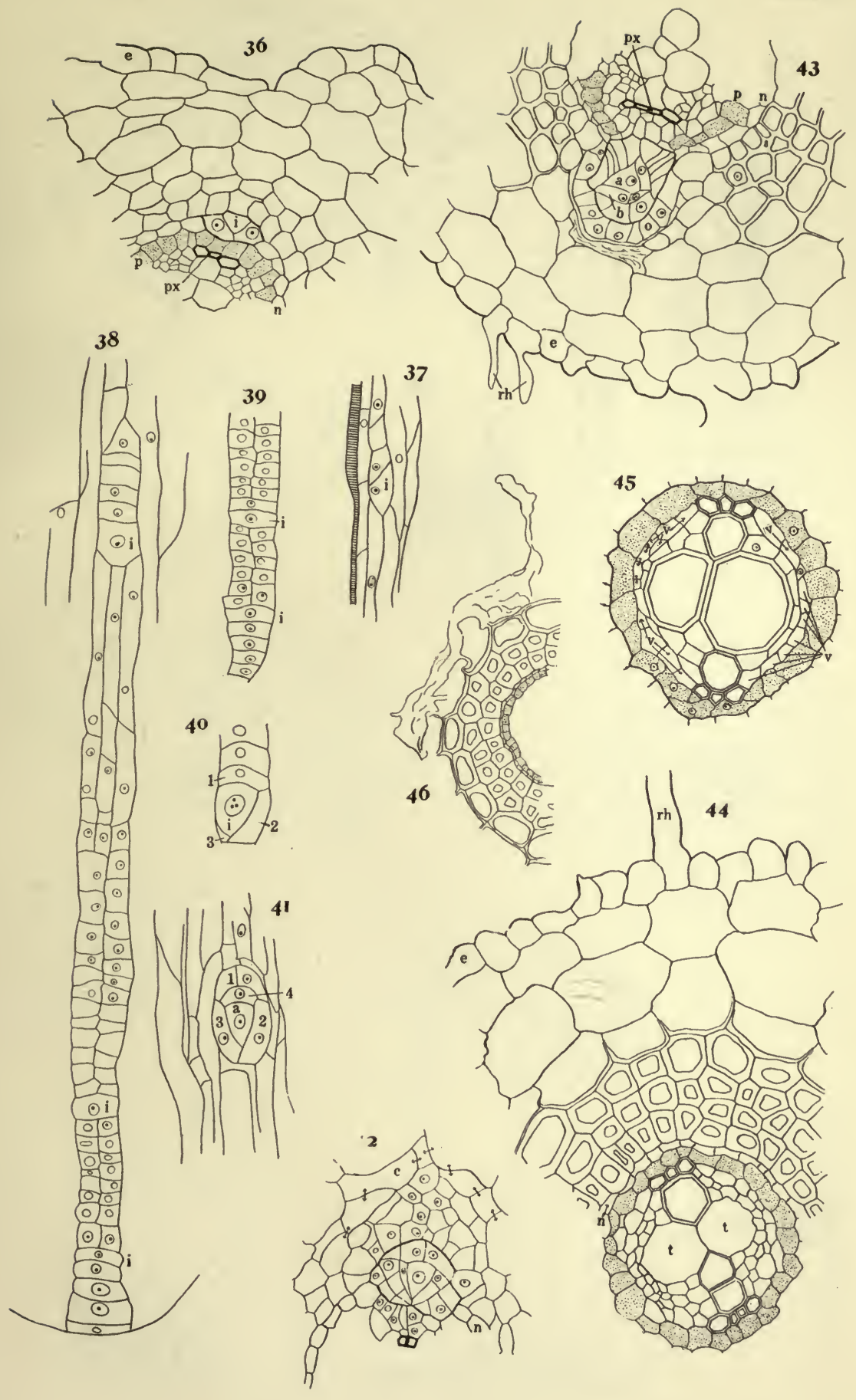



Plate 7.

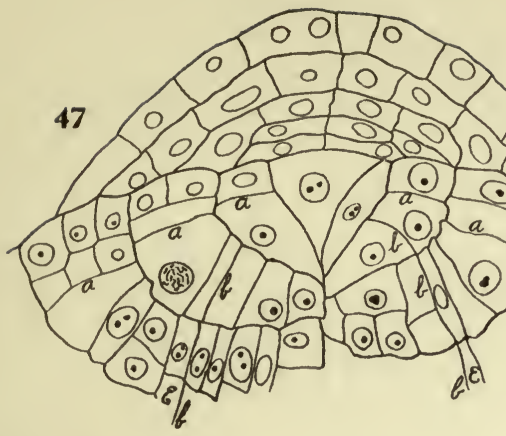

(1)
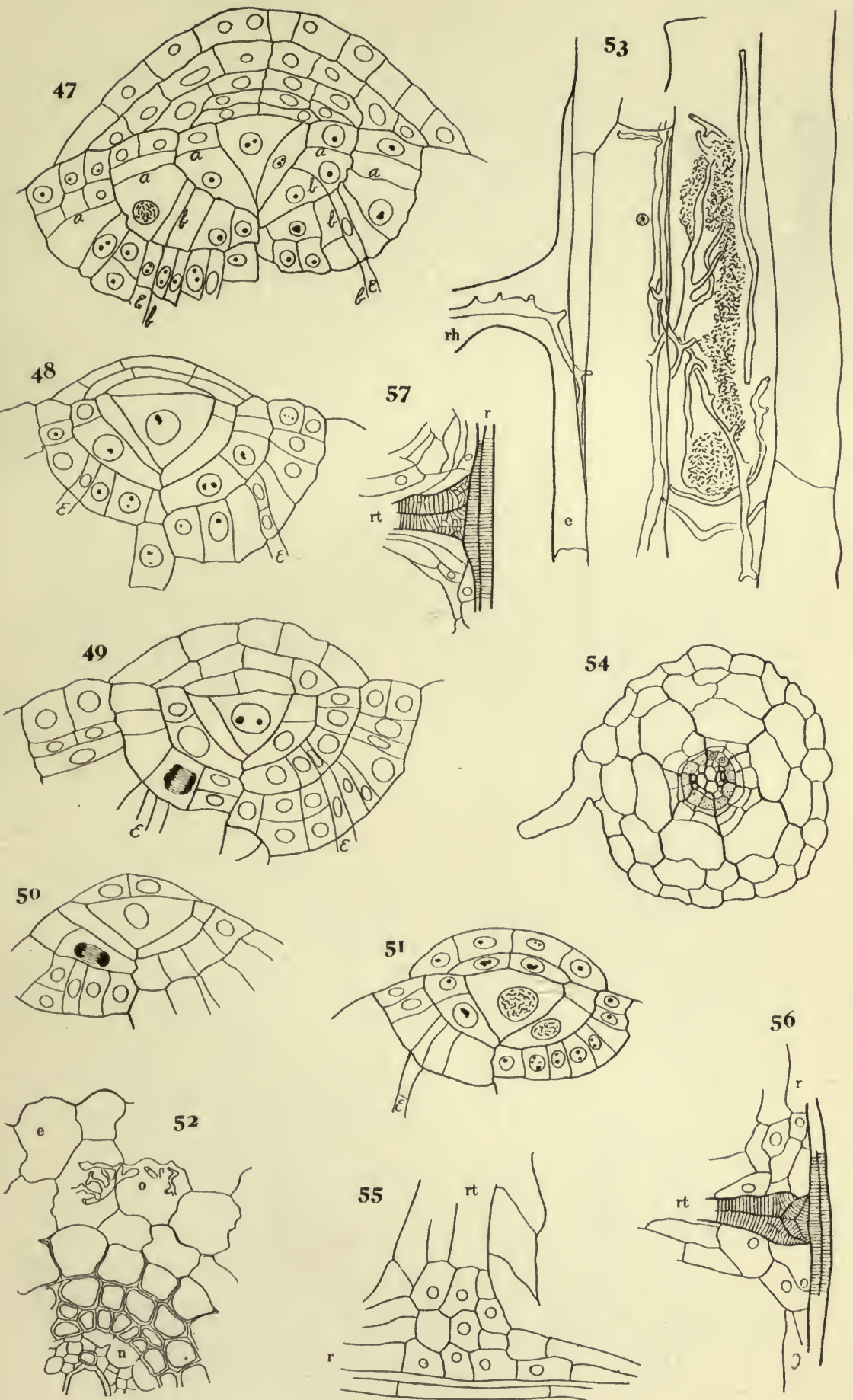

Plate 8.

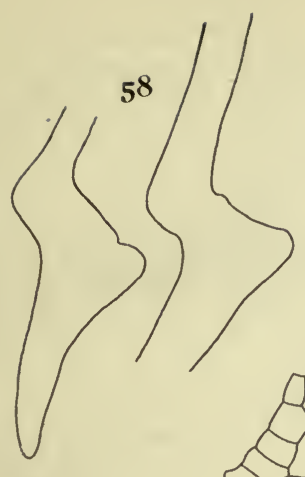

12 s

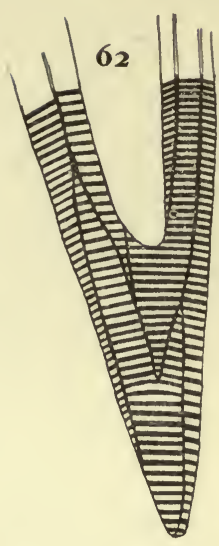

59

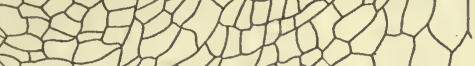

(1)

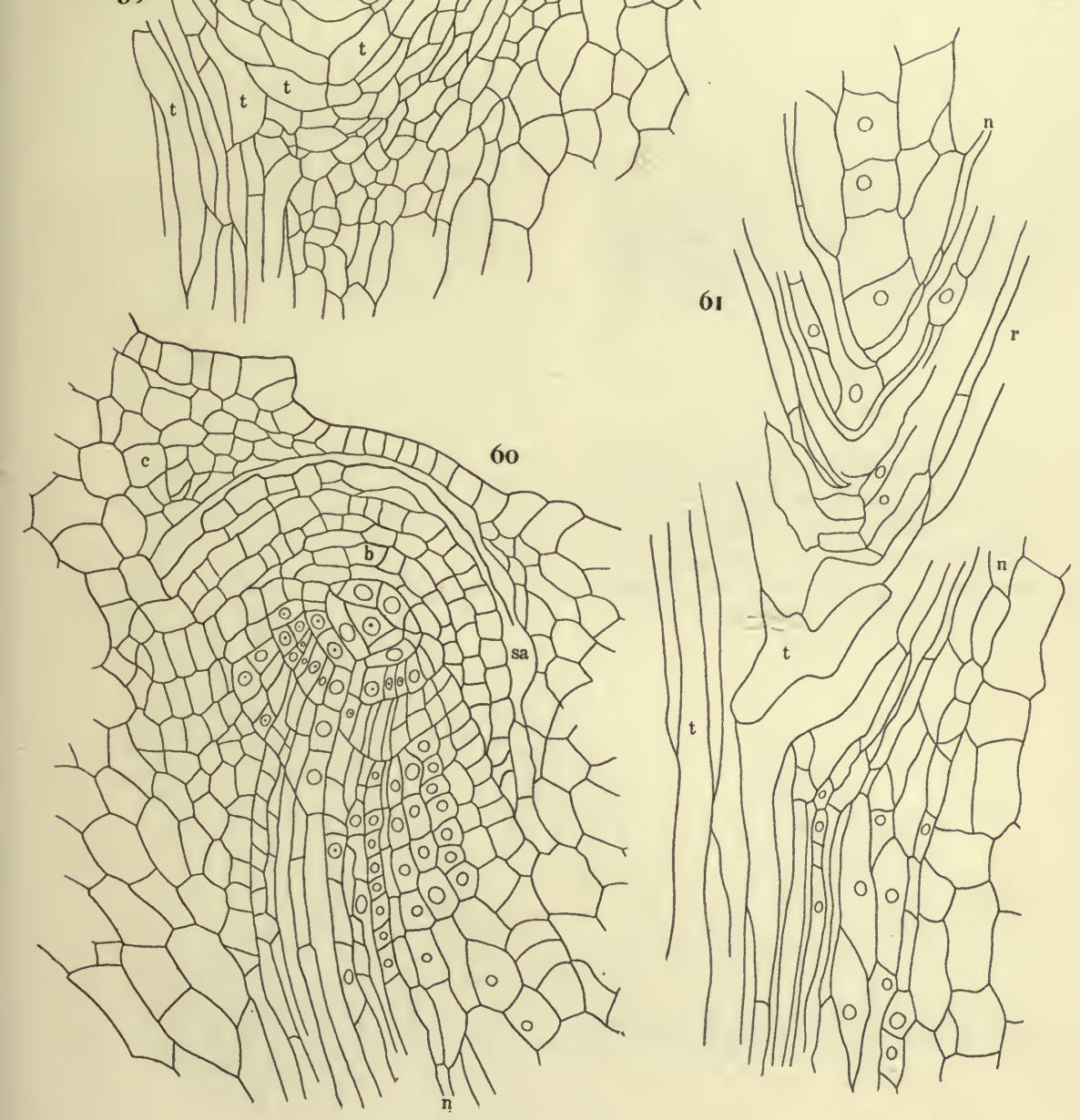



Plate 9.
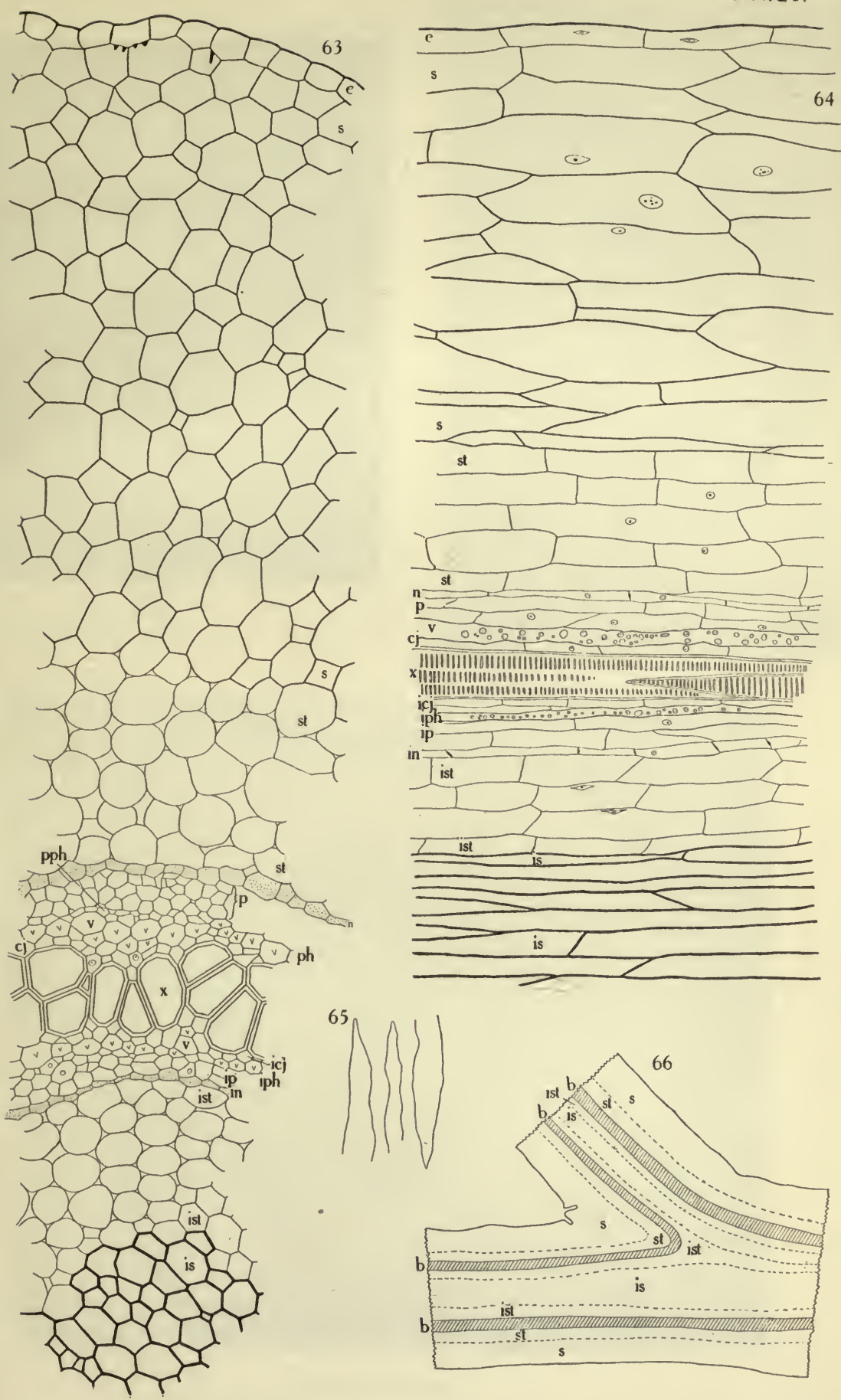


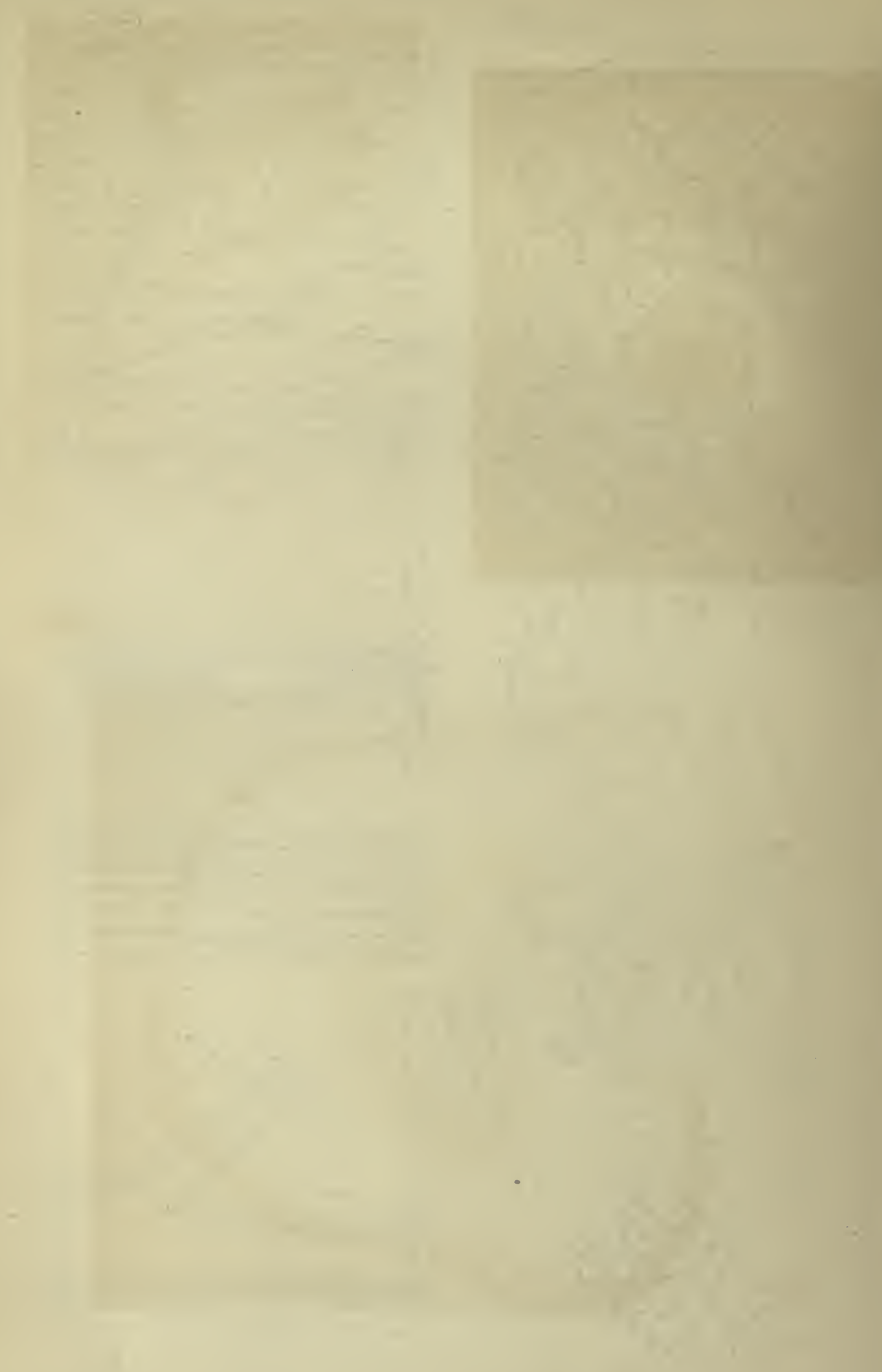

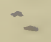




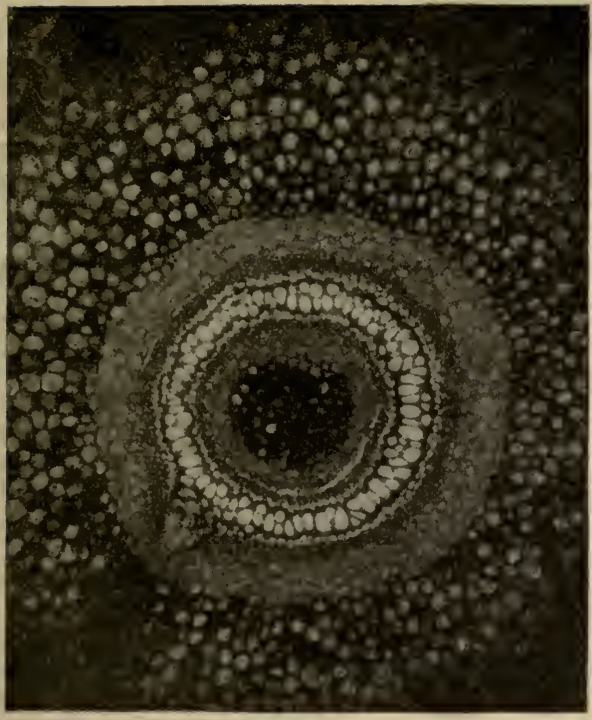

67

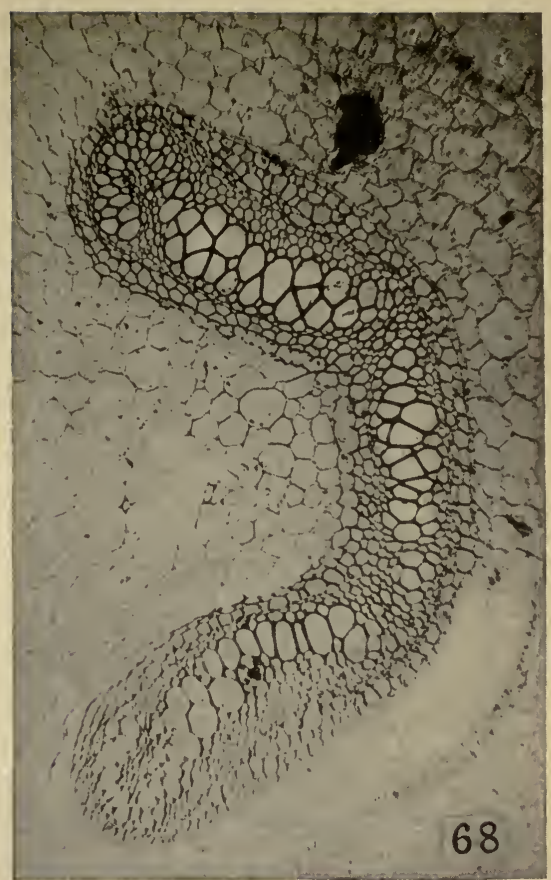

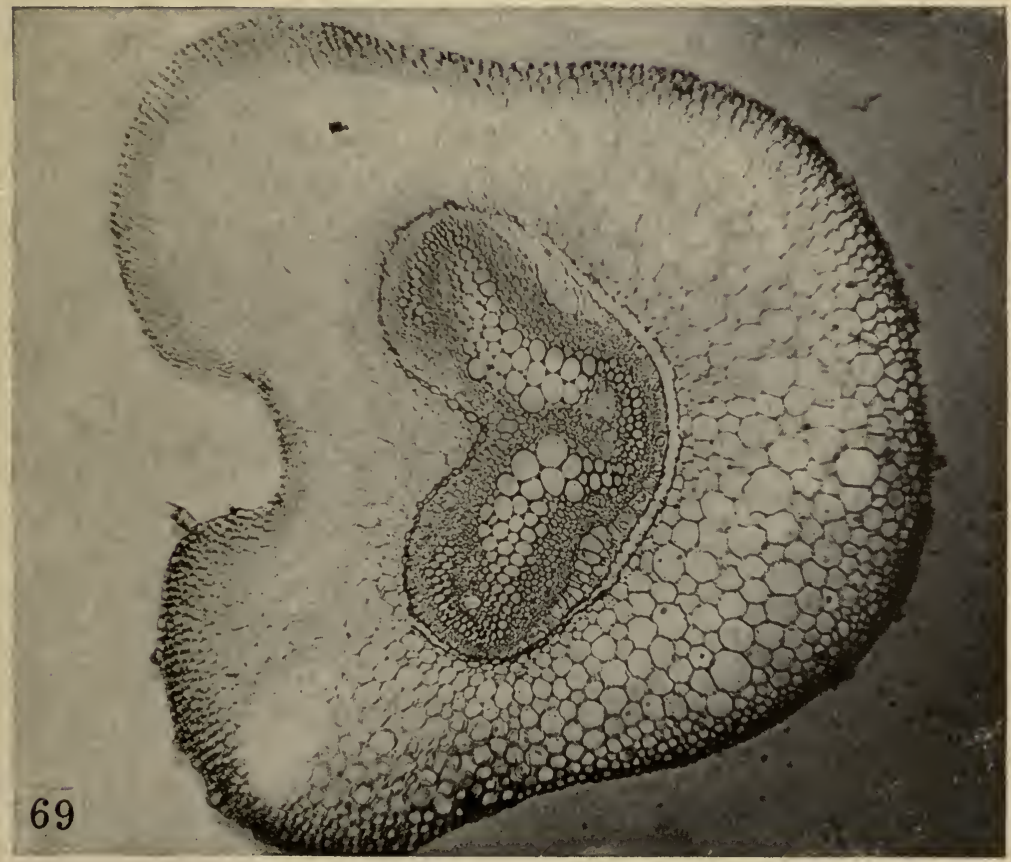

Photomicrographs.

Fig. 67. Rhizome, transverse section.

Fig. 68. Vascular bundle of petiole, transverse section.

Fig. 69. Rachis of leaf, transverse section. 

Plate 11.

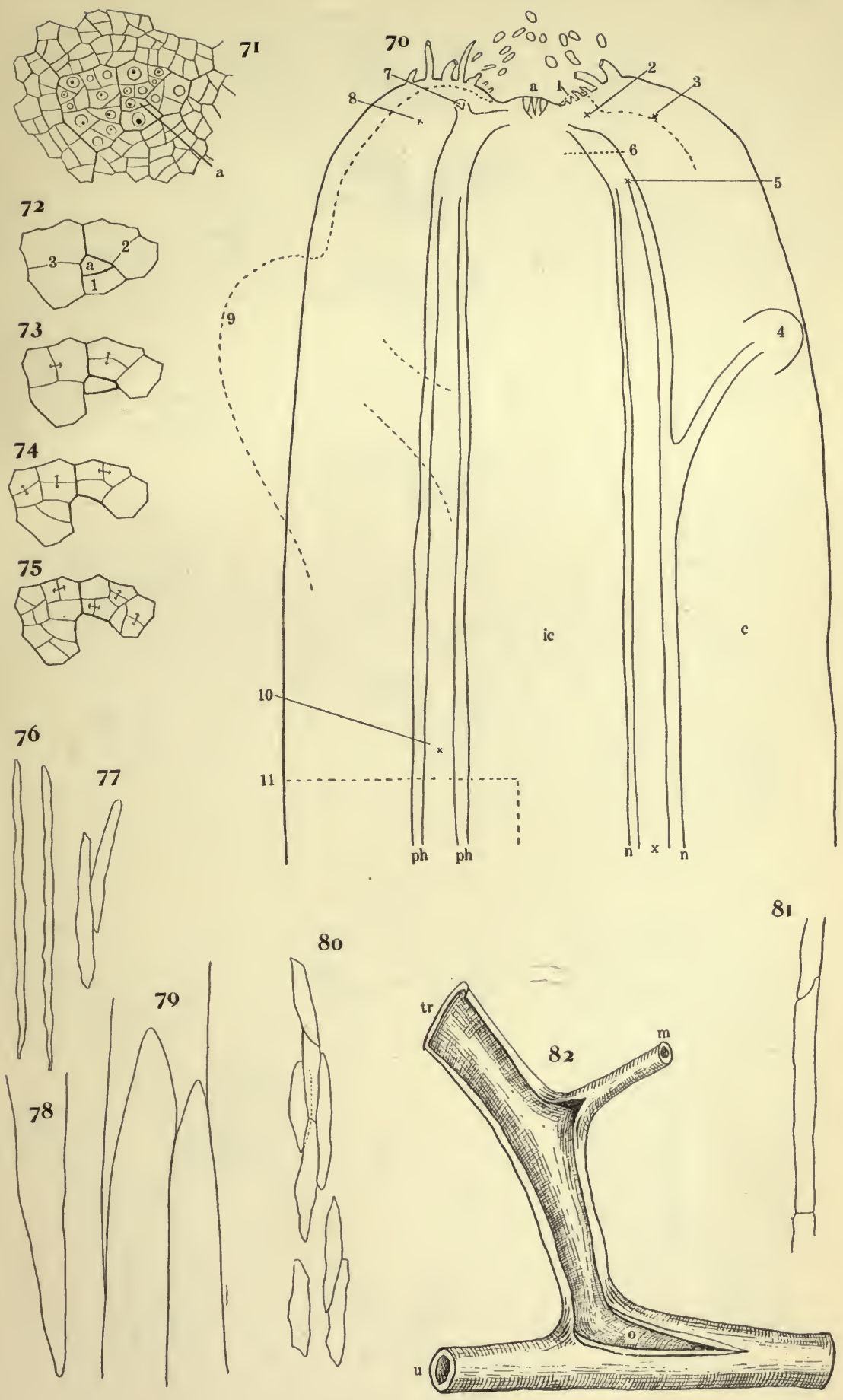



Plate 12.
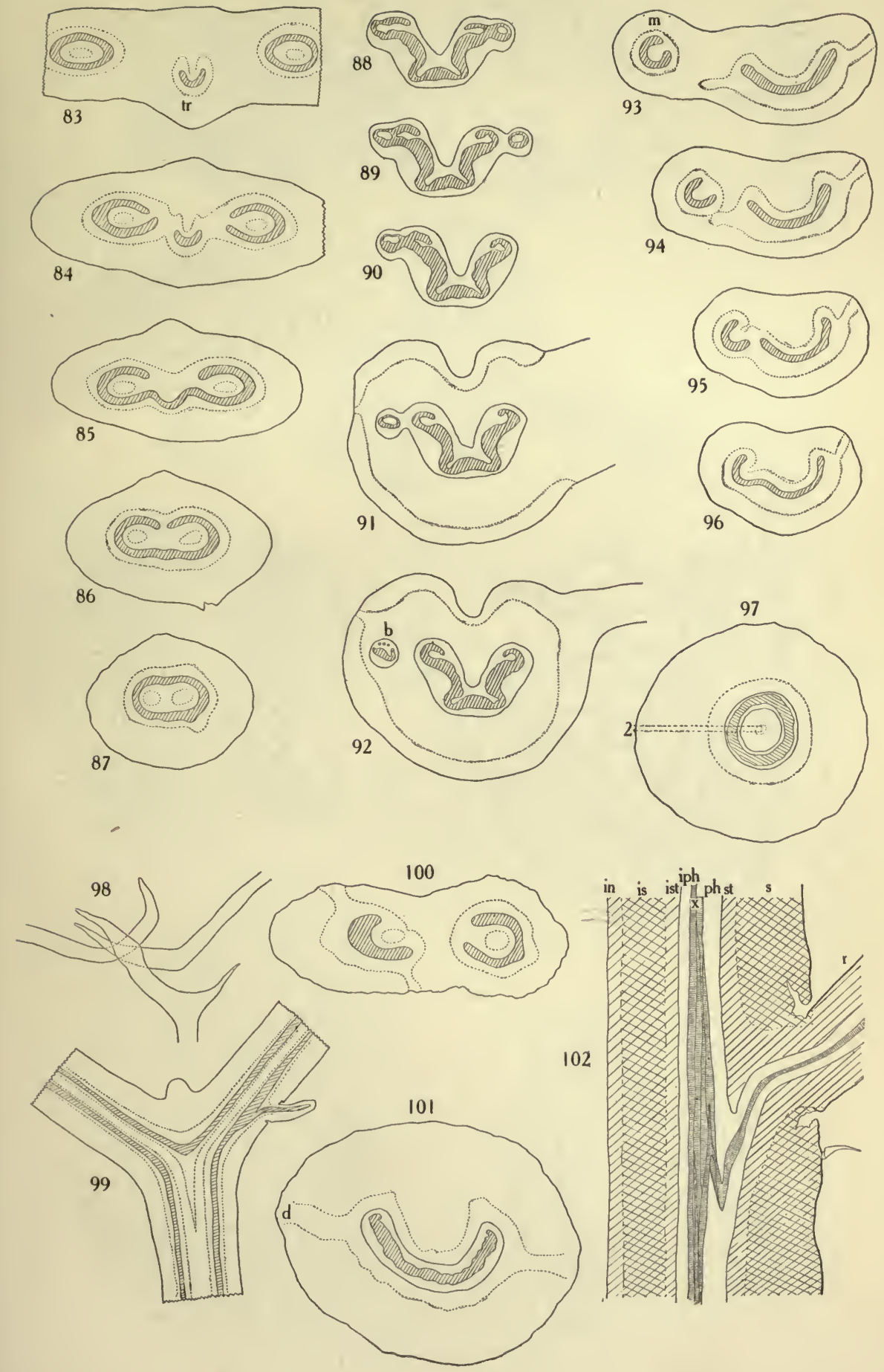



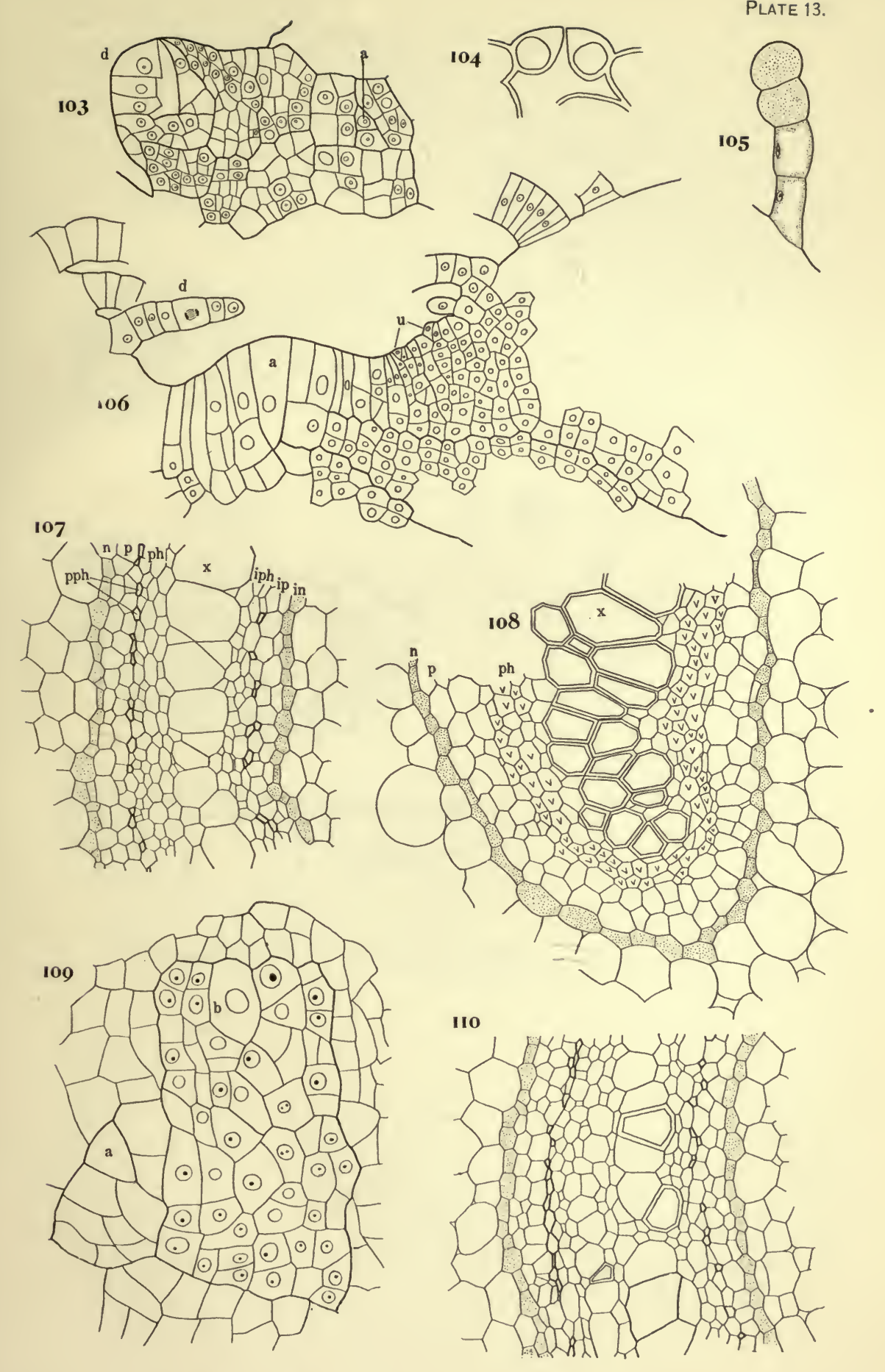



Plate 14.

"I)

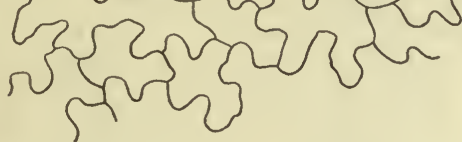
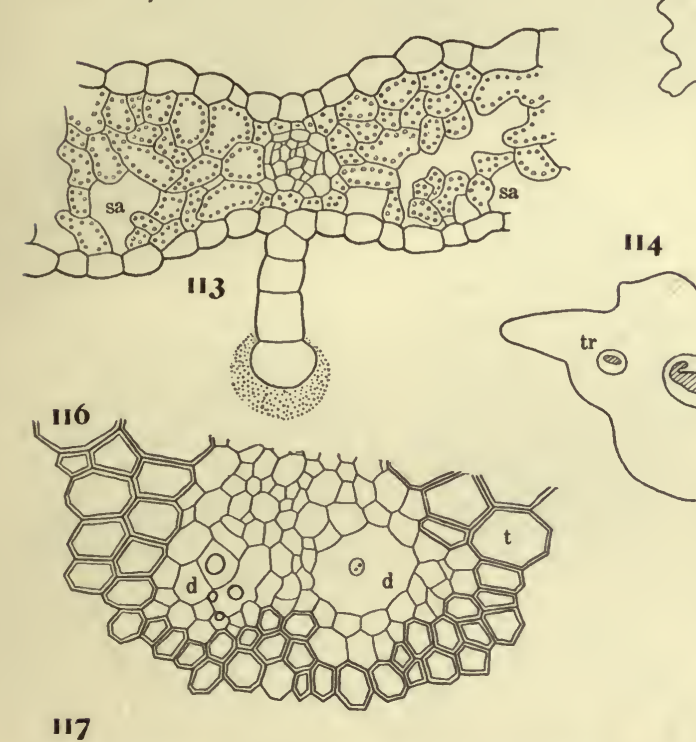

117

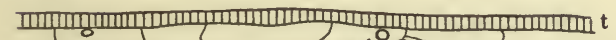

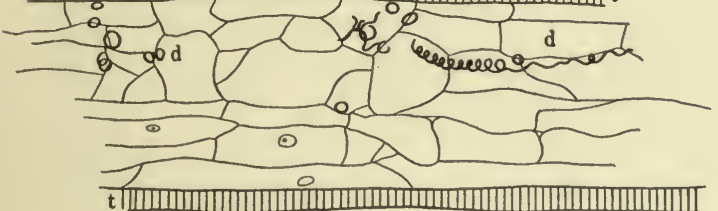

$\left\{\begin{array}{cc}3,2 \\ 2\end{array}\right\}$

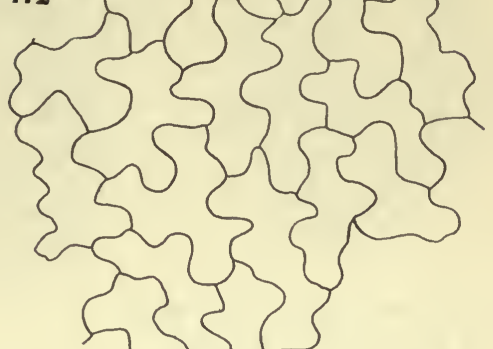
रोद

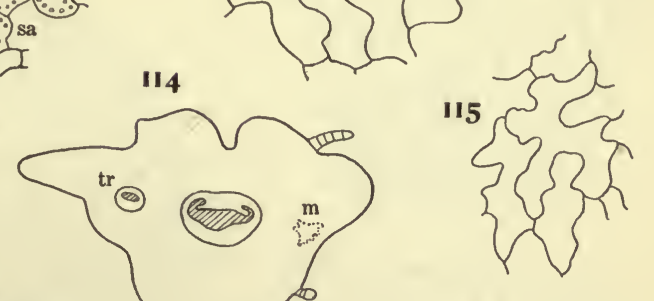

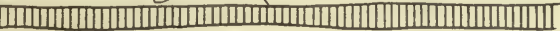
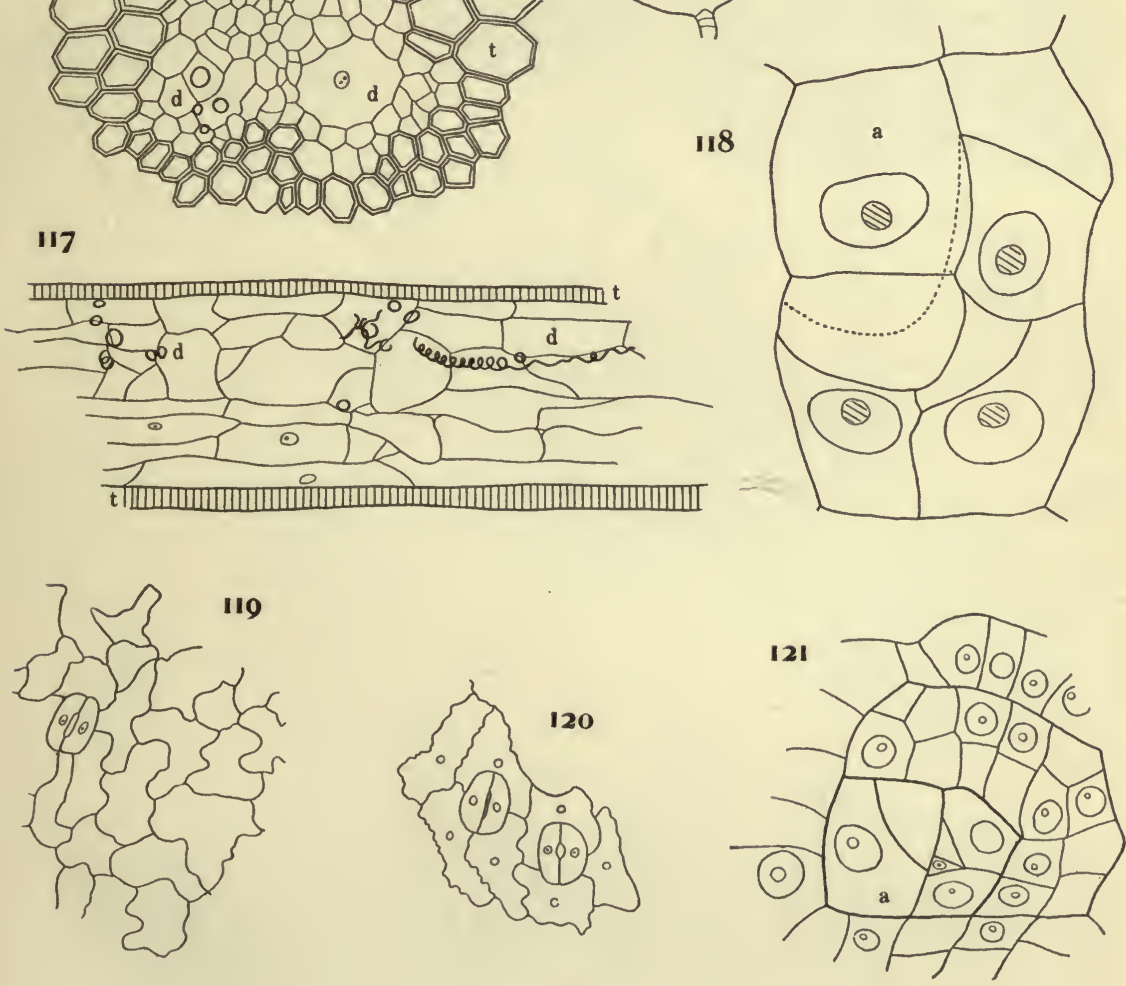

Plate 15.
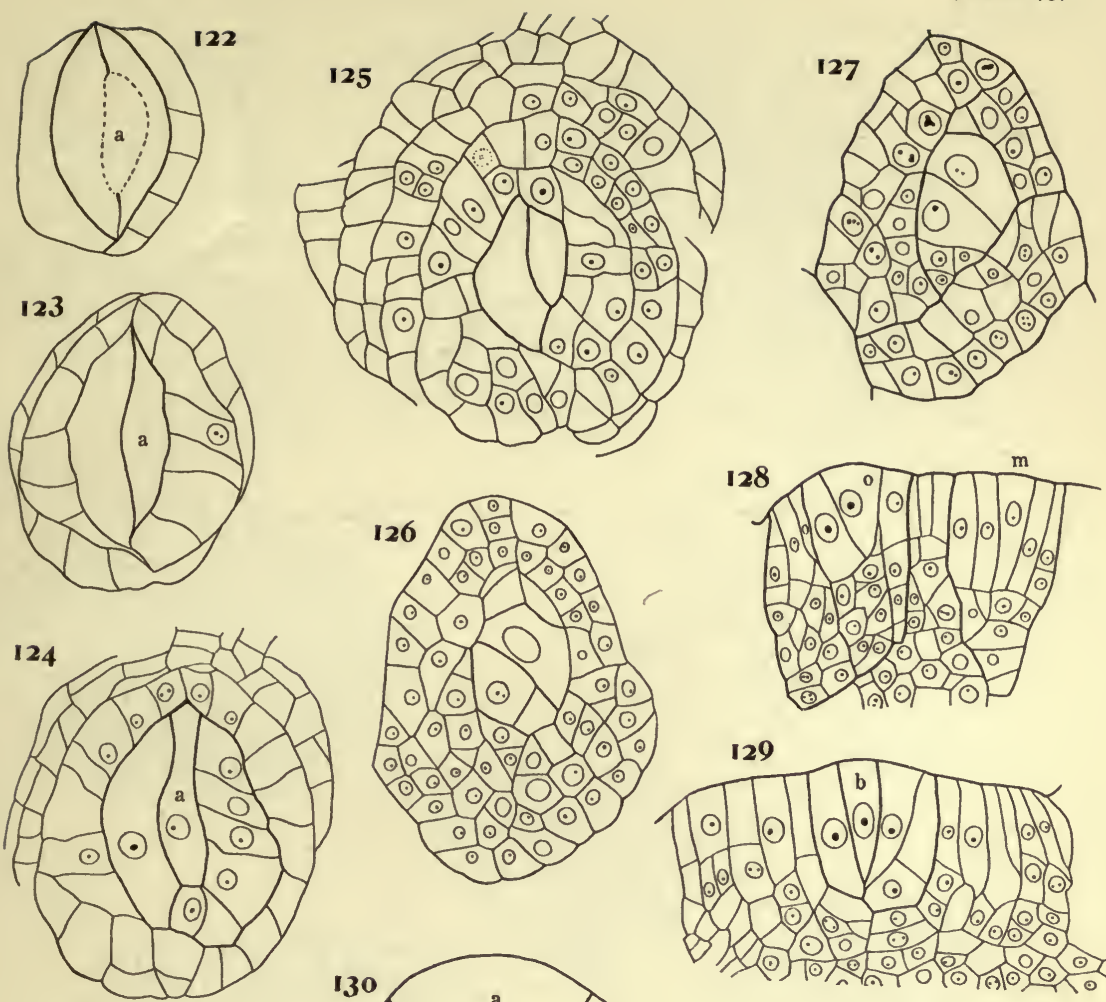
- 0 o 0 O 0.0
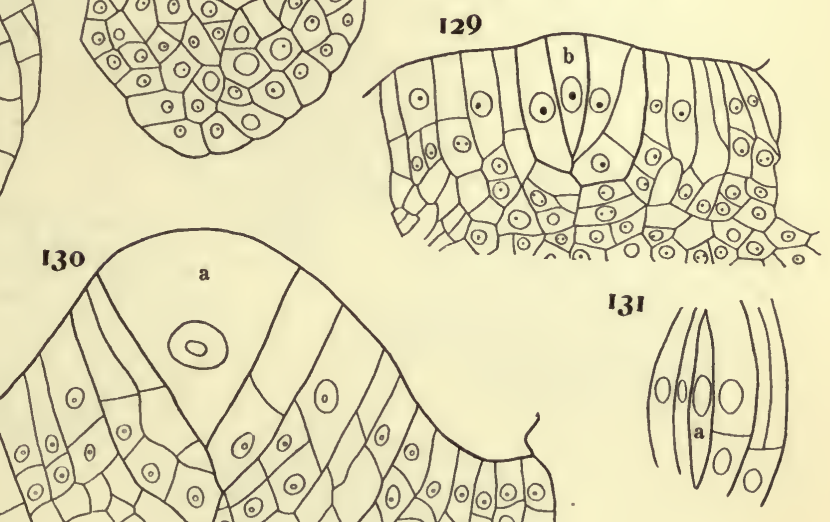

128
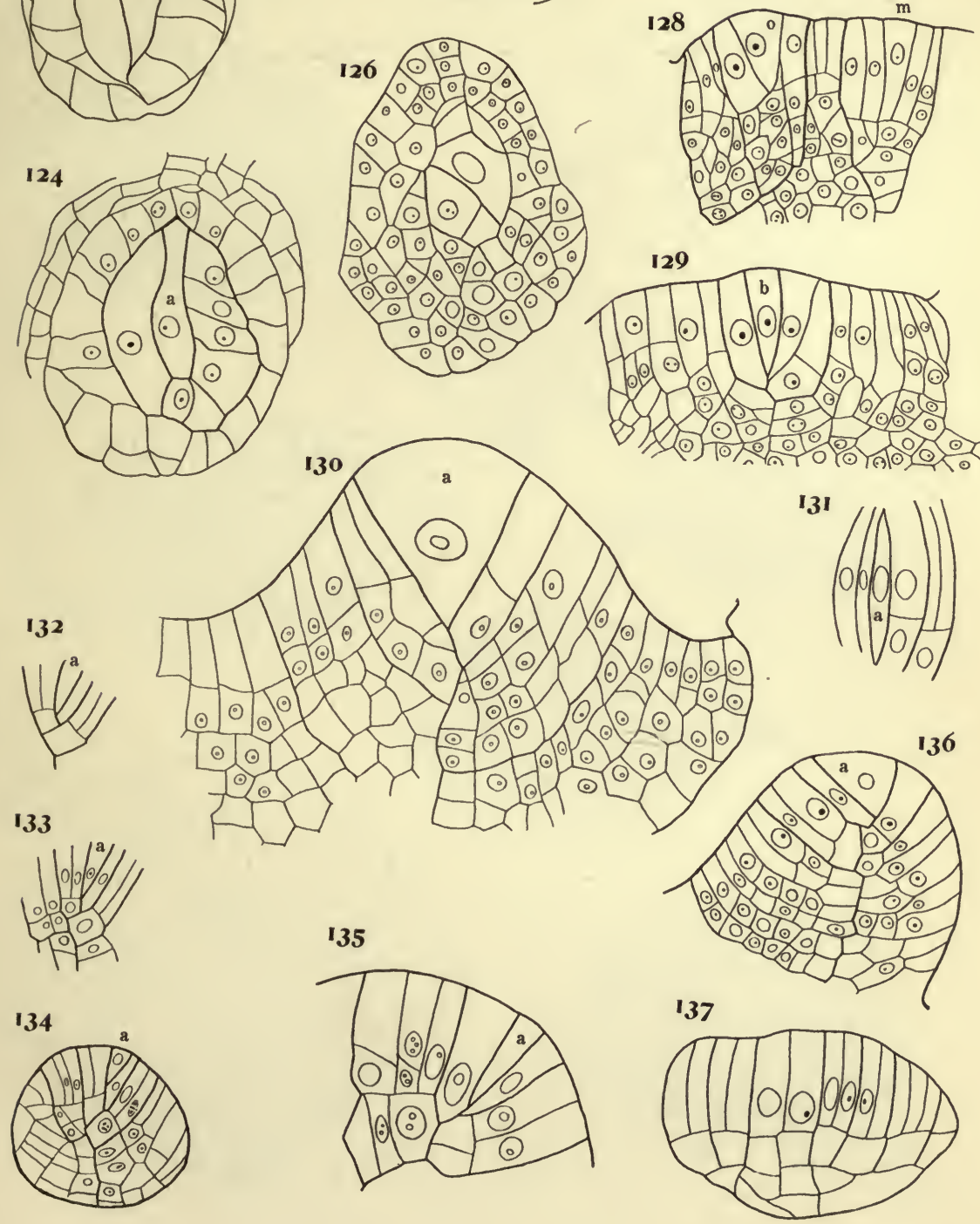

Plate 16.
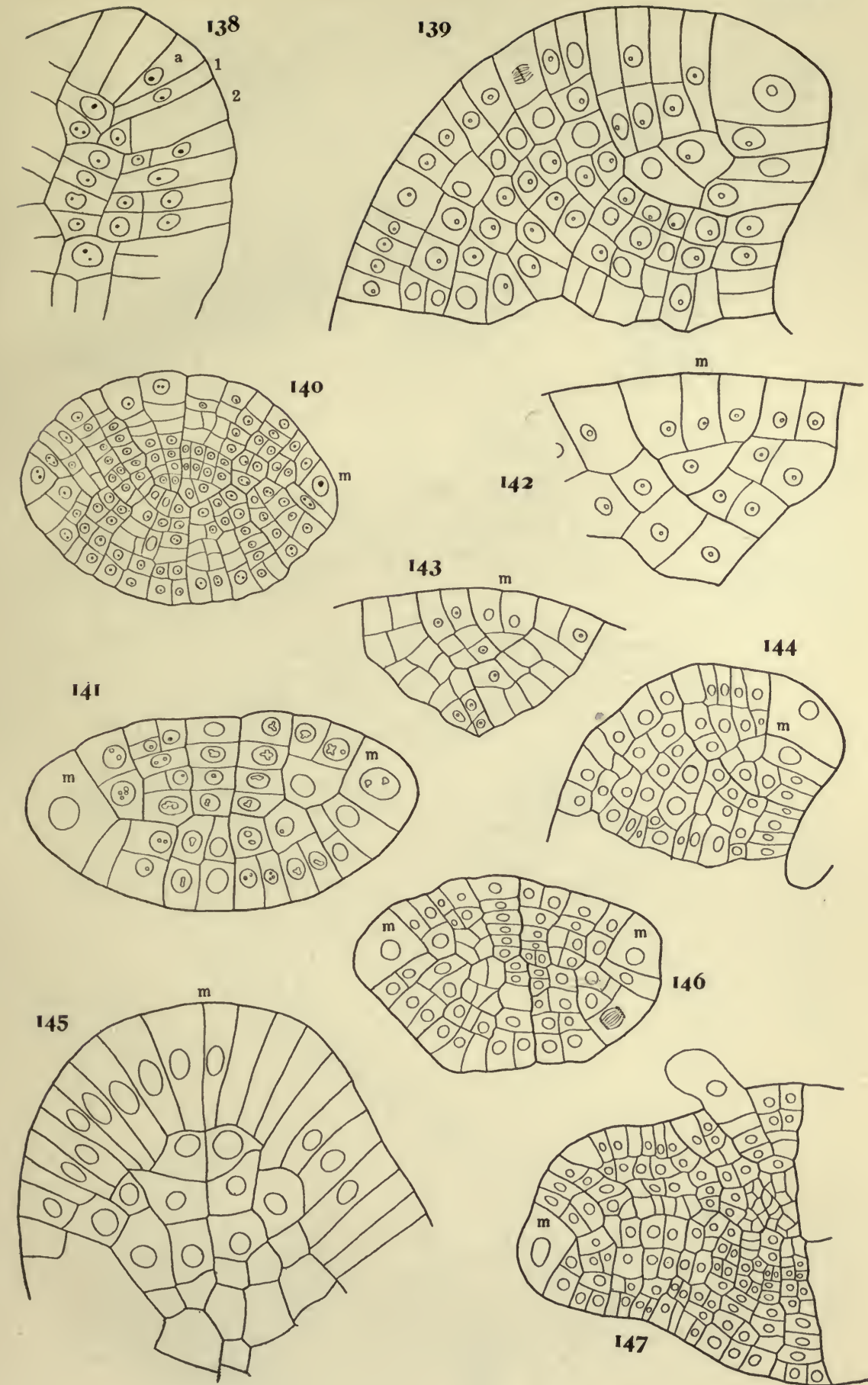

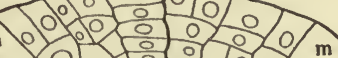
o 0 웜 0 146 0 o o o

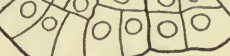

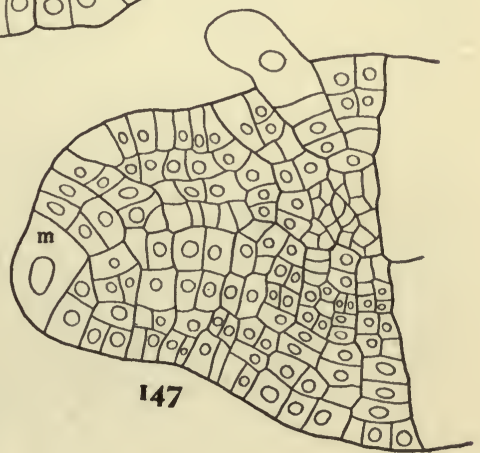



Plate 17.
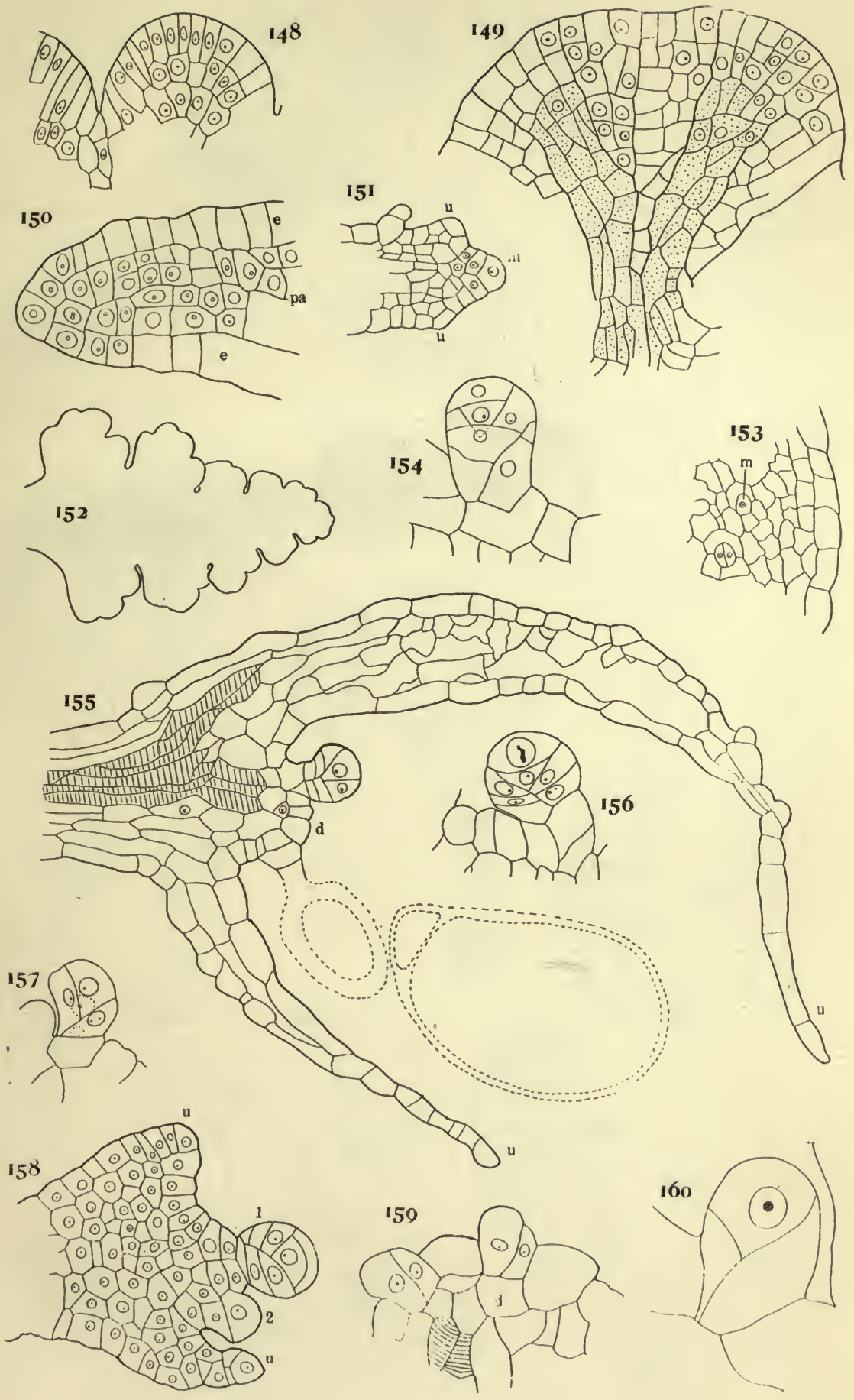

Plate 18.
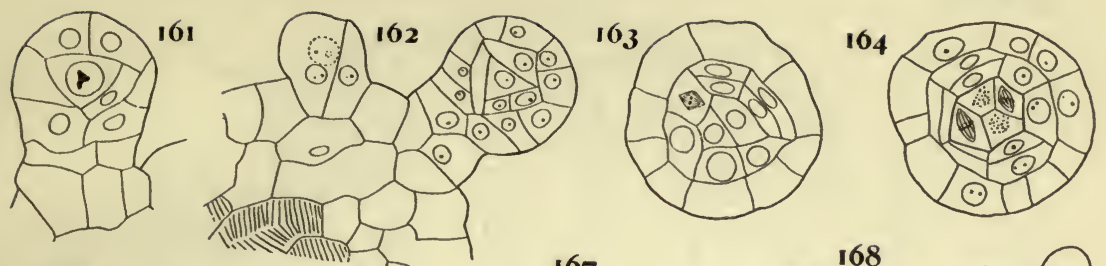

(165)
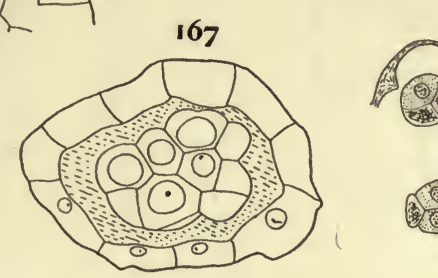

168

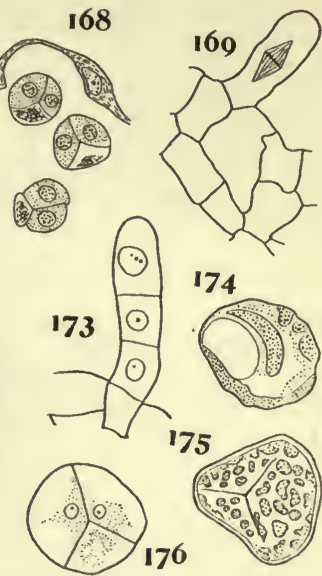

0

I7)
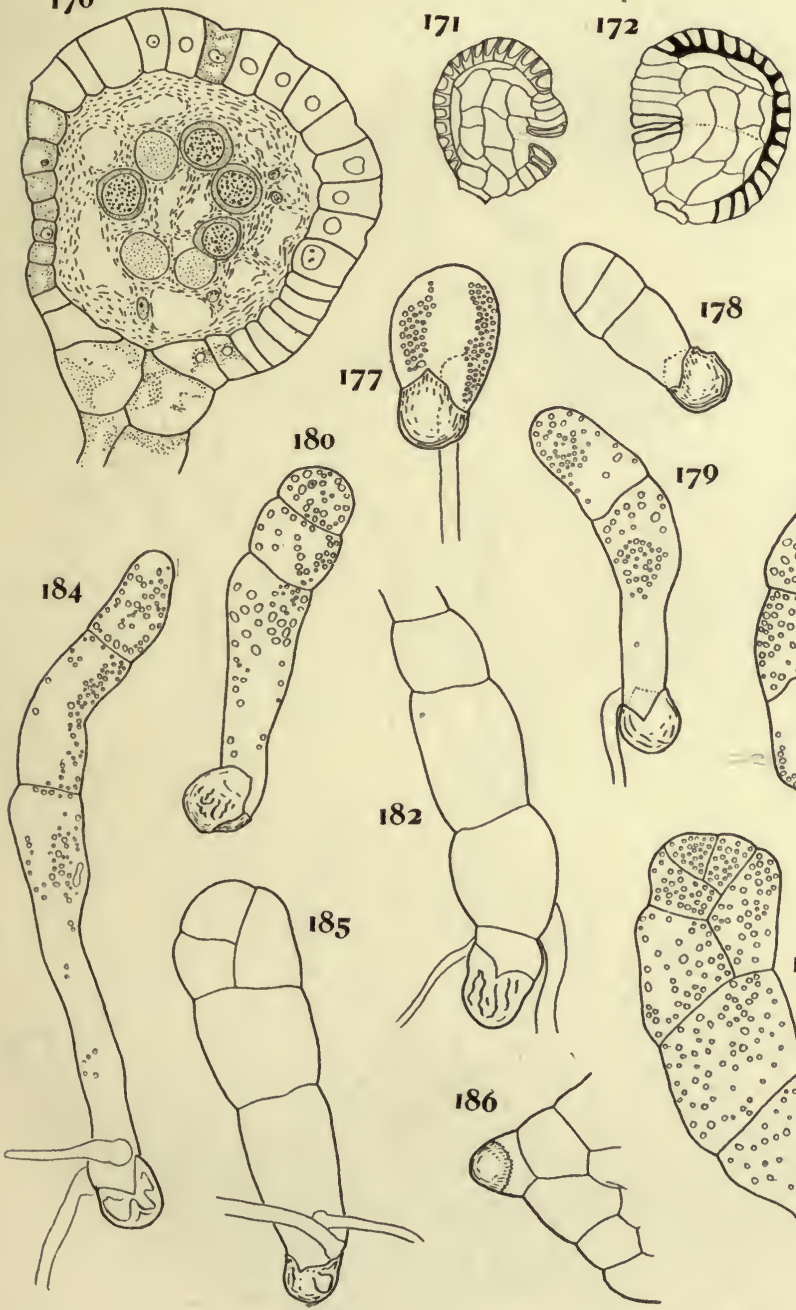

78
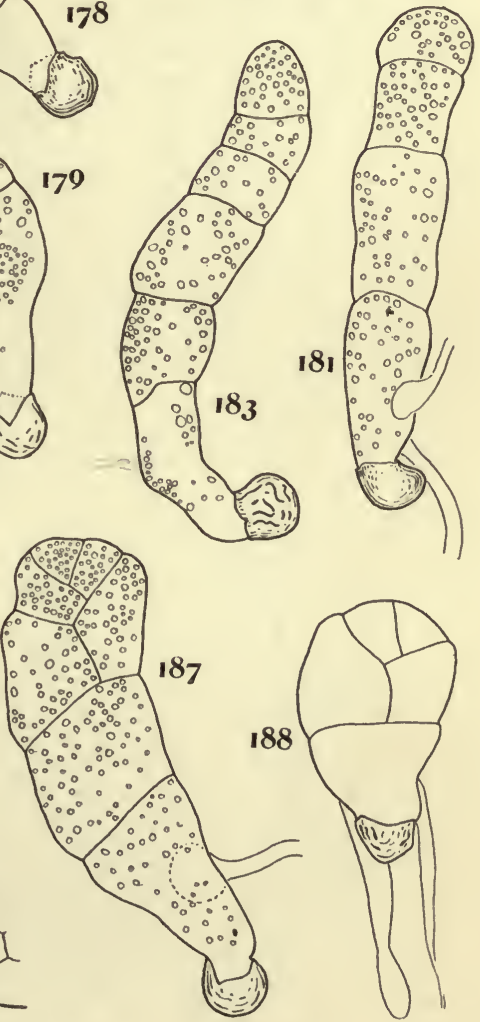



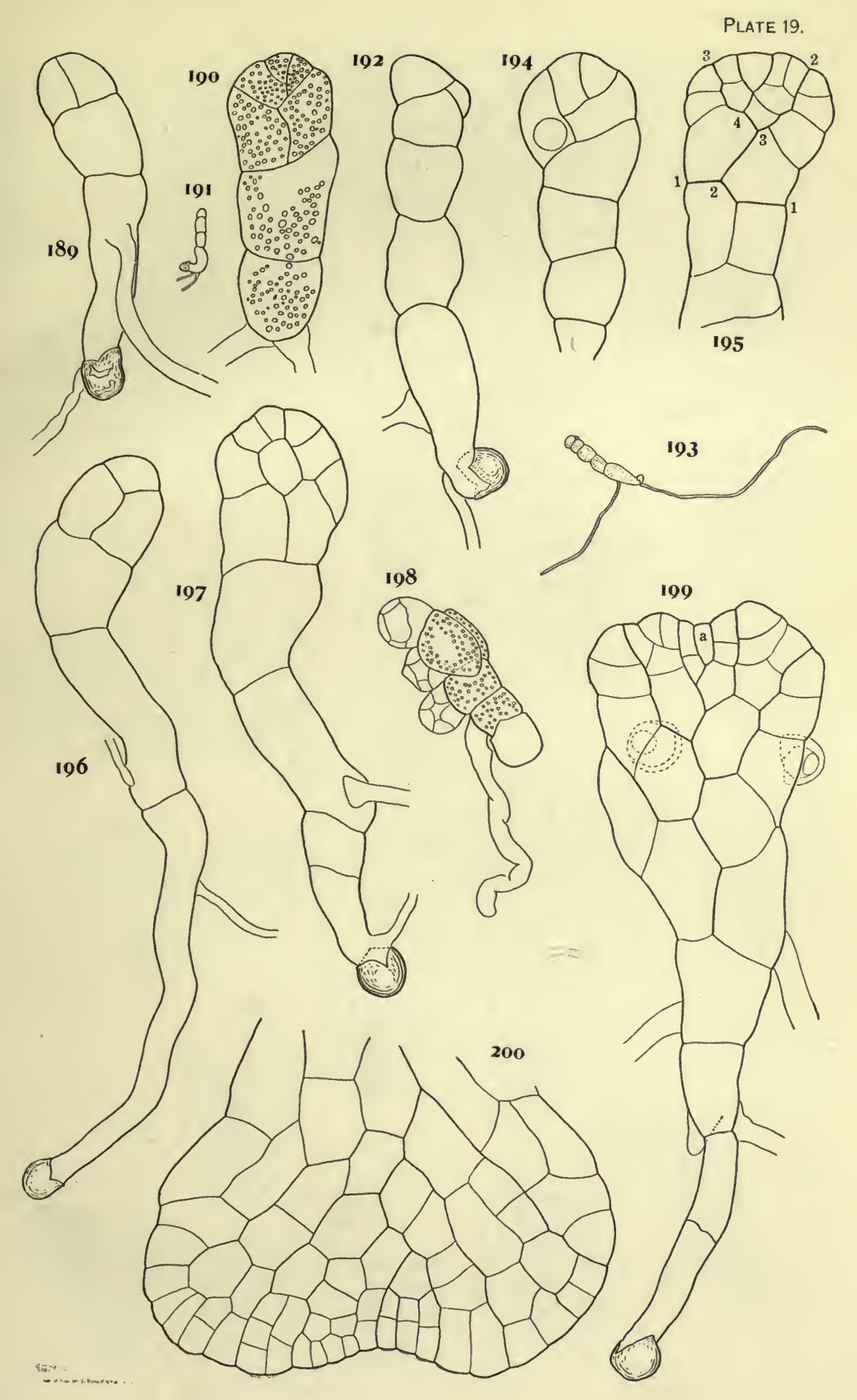




Plate 21.
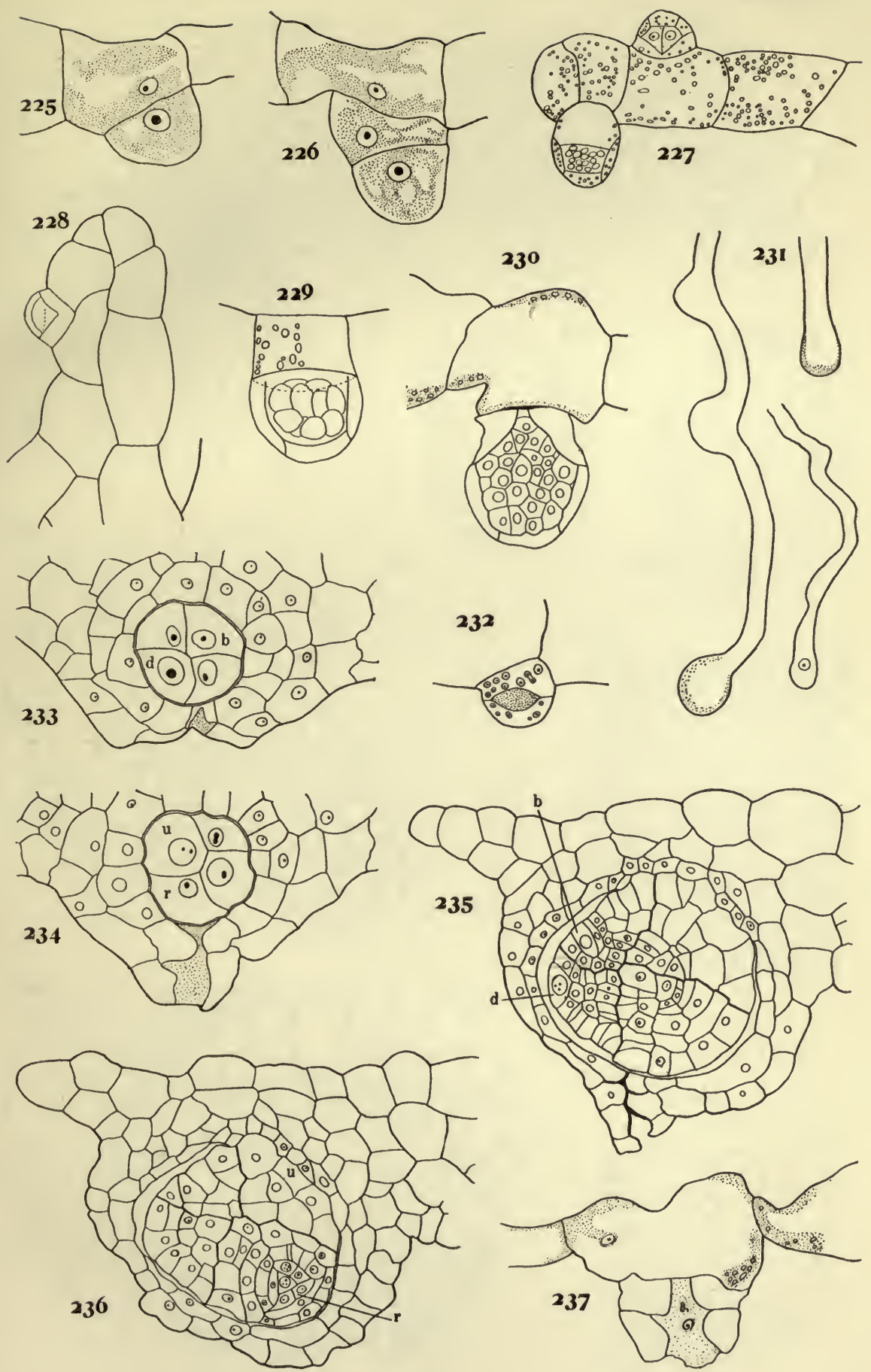

PLATE 22
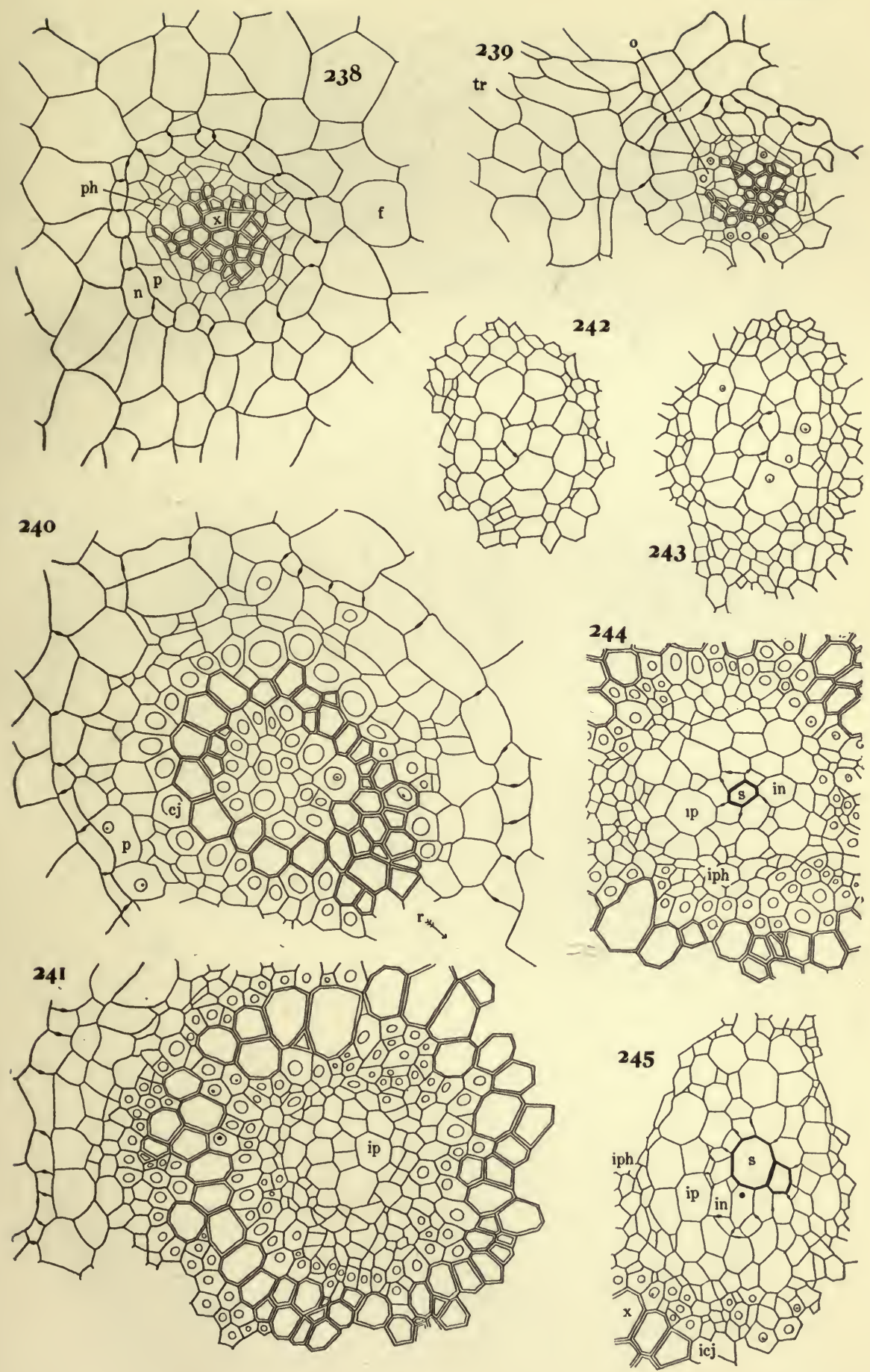

Plate 23.

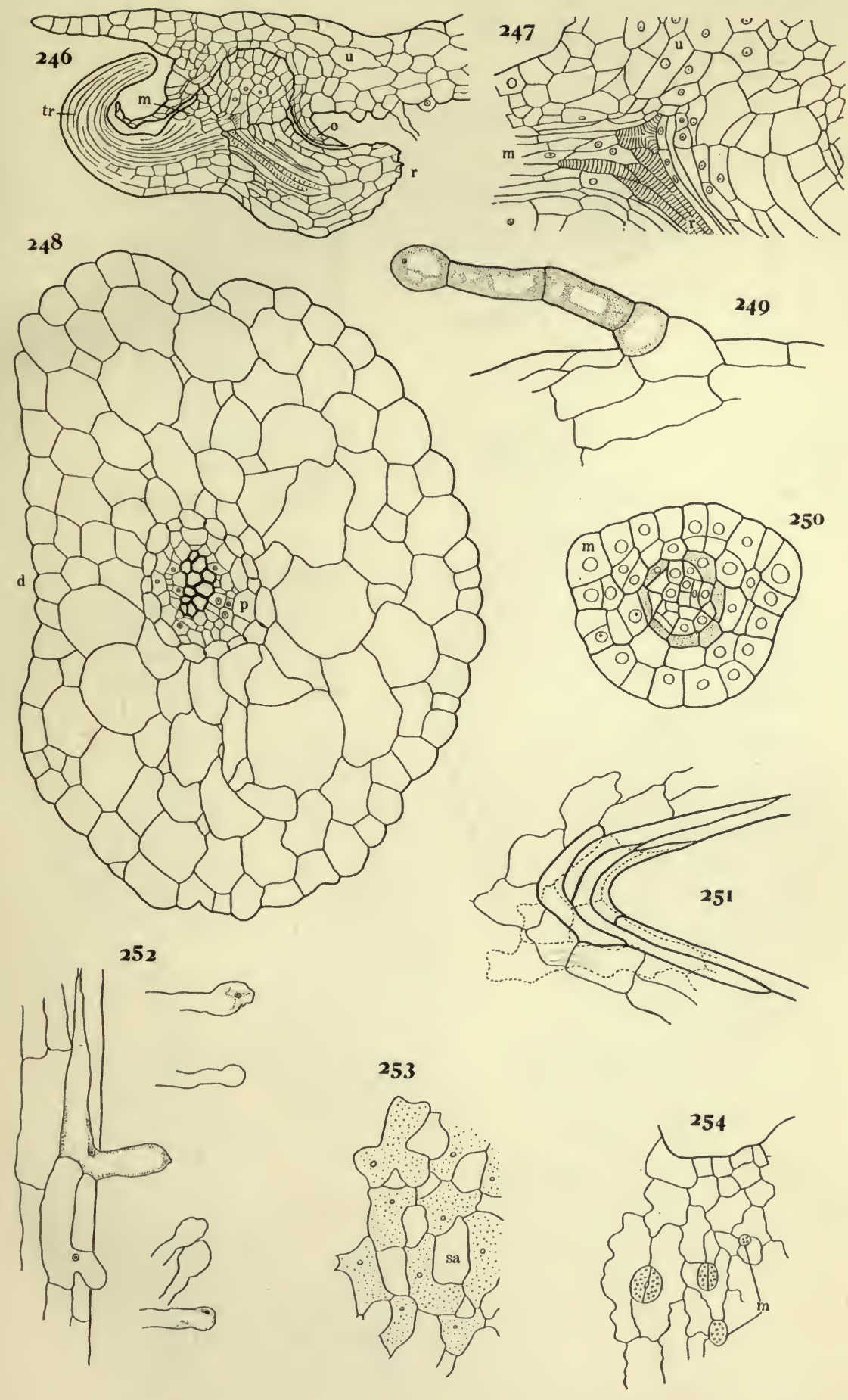



Plate 24.
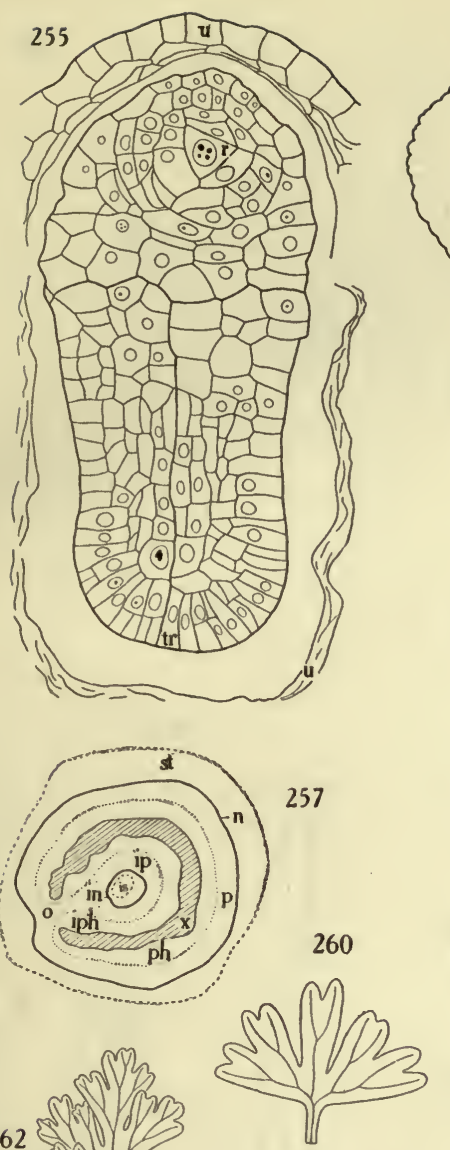

257

m MVP

262 any Now है।

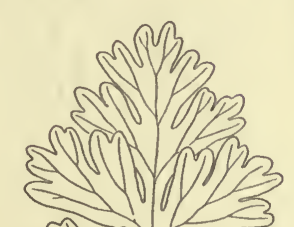
$264 \mathrm{~m}$.

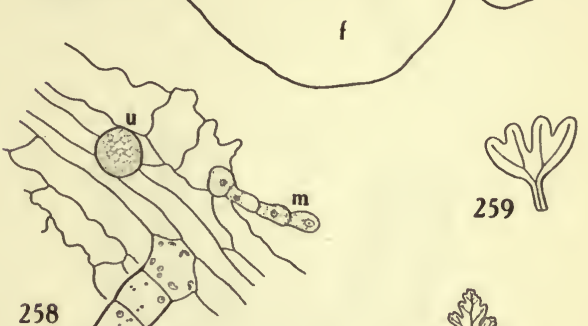

(2) 1
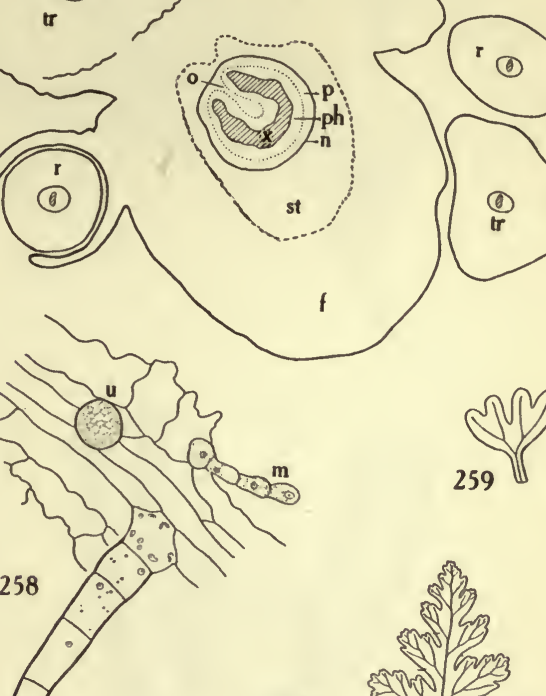

265 a्गु (2) 510010 EN 1 .

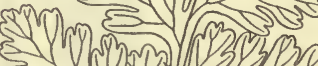
- 1 (3) SI0) है? हn (n) N 州

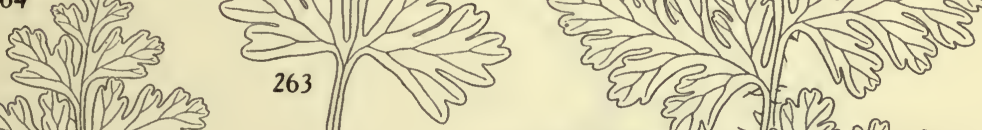

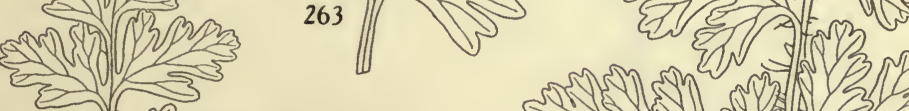

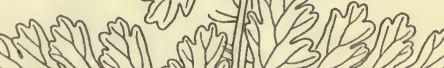

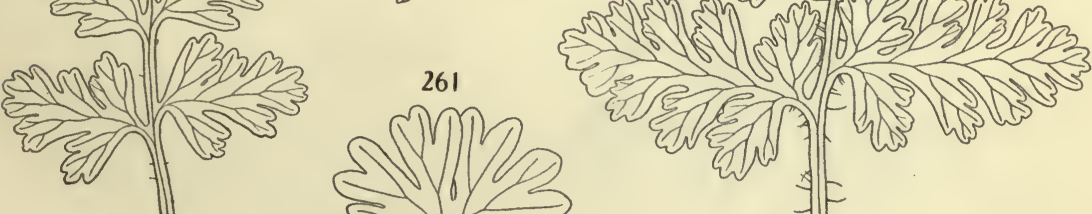



Plate 25.
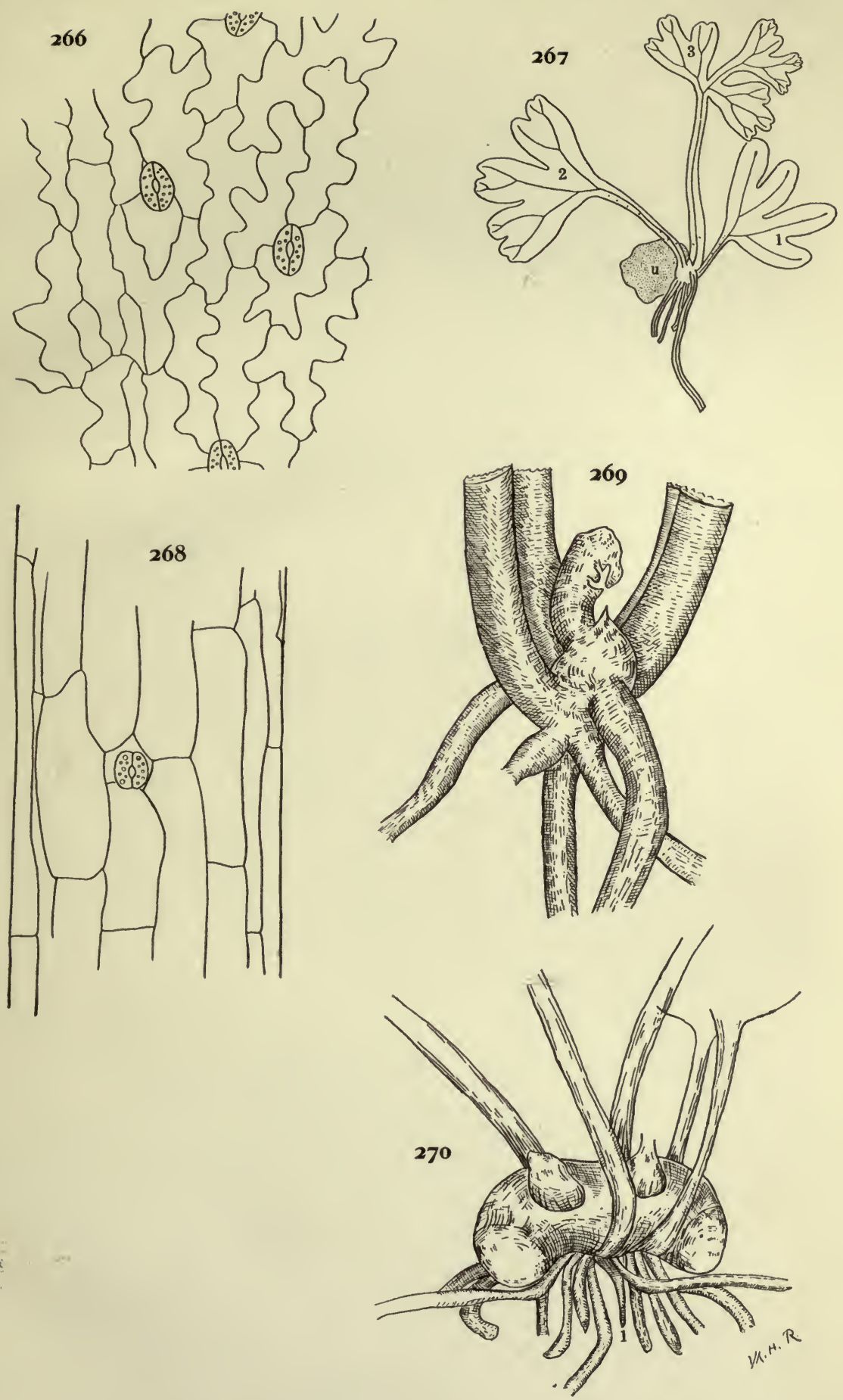



THE UNIVERSITY LIBRARY

UNIVERSITY OF CALIFORNIA, SANTA CRUZ

SCIENCE LIBRARY

This book is due on the last DATE stamped below.

To renew by phone, call 459-2050.

Books not returned or renewed within 14 days

after due date are subject to billing. 
